\title{
WRAITH - A Computer Code for Calculating Internal and External Doses Resulting from An Atmospheric Release of Radioactive Material
}

Prepared by R. I. Scherpelz, F. J. Borst, G. R. Hoenes

Pacific Northwest Laboratory

Operated by

Battelle Memorial Institute

Prepared for

U.S. Nuclear Regulatory

Commission 


\section{NOTICE}

This report was prepared as an account of work sponsored by an agency of the United States Government. Neither the United States Government nor any agency thereof, or any of their employees, makes any warranty, expressed or implied, or assumes any legal liability or responsibility for any third party's use, or the results of such use, of any information. apparatus product or process disclosed in this report, or represents that its use by such third party would not infringe privately owned rights.

Available from

GPO Sales Program

Division of Technical Information and Document Control

U. S. Nuclear Regulatory Commission Washington, D. C. 20555

Printed copy price: $\$ 5.50$

and

National Technical Information Service

Springfield, Virginia 22161 
NUREG/CR-1690

PNL-3382

RA

\section{WRAITH - A Computer Code for Calculating Internal and External Doses Resulting From An Atmospheric Release of Radioactive Material}

Manuscript Completed: Auqust 1980

Date Published: December 1980

Prepared by

R. I. Scherpelz, F. J. Borst, G. R. Hoenes

Pacific Northwest Laboratory

Richland, WA 99352

Prepared for

Division of Safeguards, Fuel Cycle and Environmental Research

Office of Nuclear Regulatory Research

U.S. Nuclear Regulatory Commission

Washington, D.C. 20555

NRC FIN No. B2268 



\section{ABSTRACT}

WRAITH is a FORTRAN computer code which calculates the doses received by a standard man exposed to an accidental release of radioactive material. The movement of the released material through the atmosphere is calculated using a bivariate straight-line Gaussian distribution model, with Pasquill values for standard deviations. The quantity of material in the released cloud is modified during its transit time to account for radioactive decay and daughter production. External doses due to exposure to the cloud can be calculated using a semi-infinite cloud approximation. In situations where the semi-infinite cloud approximation is not a good one, the external dose can be calculated by a "finite plume" three-dimensional point-kernel numerical integration technique. Internal doses due to acute inhalation are calculated using the ICRP Task Group Lung Mode1 and a four-segmented gastro-intestinal tract model. Translocation of the material between body compartments and retention in the body compartments are calculated using multiple exponential retention functions. Internal doses to each organ are calculated as sums of cross-organ doses, with each target organ irradiated by radioactive material in a number of source organs. All doses are calculated in rads, with separate values determined for high-LET and low-LET radiation. 


\section{SUMMARY}

WRAITH is a computer code written in ASCII FORTRAN, which calculates the doses resulting from an atmospheric release of radioactive material. The user supplies a source term, including the quantity and solubility class of each radionuclide in the release, and specific information describing the atmospheric conditions at the time of the release. WRAITH calculates the atmospheric transport of the radioactive material to each of a number of downwind receptor points, and calculates the external and internal doses to a reference man at each of the receptor points.

The external dose calculation can be performed by assuming that the reference man is submersed in a semi-infinite cloud or by assuming that the reference man is exposed to a plume of finite dimensions. The finite plume caiculation can assume that the plume is overhead, or that the dose point is anywhere inside the plume. This calculation is performed using a threedimensional point-kernel integration.

The internal dose commitment evaluation assumes that the material is introduced into the body by acute inhalation. The ICRP Task Group Lung Model and a four-compartment gastrointestina? tract model are used to calculate radionuclide movement in the body. Clearance of the radioactive material from other organs in the body is evaluated using multiple exponential retention functions for the organ. Doses to each organ are calculated using a crossorgan dose evaluation method in which radioactive material residing in each "source organ" irradiates each "target organ."

Doses to each target organ from all internal and external sources of radiation are summed at each receptor point. All doses are evaluated in units of rads, with separate evaluations for low-LET and high-LET radiation. These doses can then be converted to dose equivalents (in units of rems), using a value for the quality factor for high-LET radiation supplied by the user. 


\section{CONTENTS}

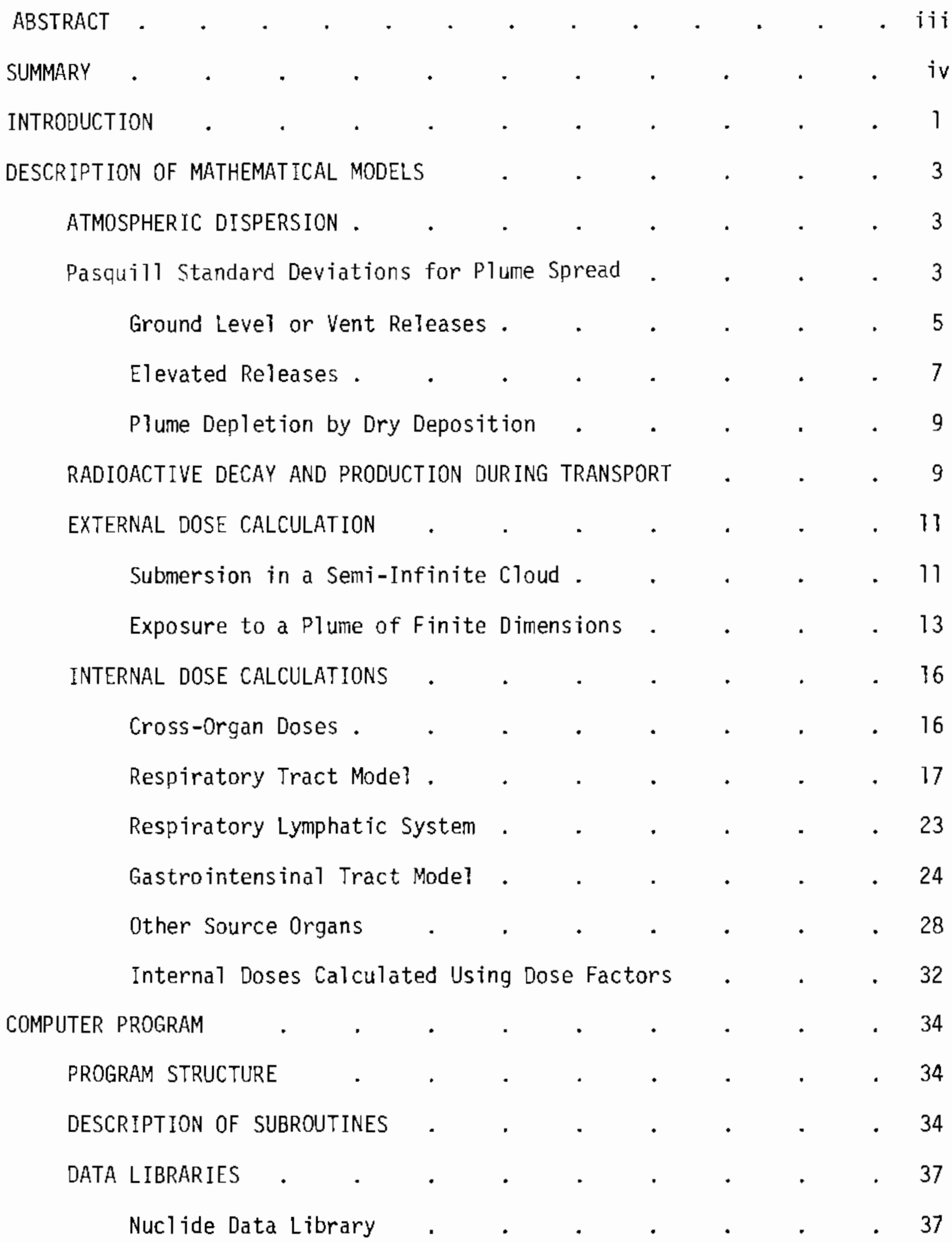


Organ Data Library $\quad . \quad$. $\quad . \quad$. $\quad . \quad$. $\quad . \quad 38$

S-Factor Data Library . . . . . . . . . . . 41

Status of Nuclides in Data Libraries . . . . . . 43

PROGRAM EXECUTION . . . . . . . . . . . . . . 49

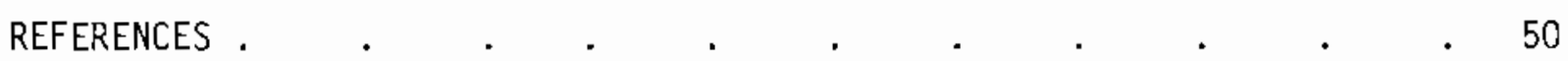

APPENDIX A - LISTING OF CODE SOURCE DECK . . . . . . A-1

APPENDIX B - DICTIONARY OF VARIABLES IN COMMON $. . \quad . \quad . \quad$. B-1

APPENDIX C - LISTING OF DATA LIBRARIES . . . . . . . . . C-

APPENDIX D - WRAITH EXECUTION . . . . . . . . . . D- . . . .

APPENDIX E - SAMPLE PROBLEMS . . . . . . . . . . . E-T

MICROFICHE (Attached to inside back cover) 


\section{FIGURES}

1 Determination of $M$, a Correction to Pasquill $\sigma_{y}$ Values . $\quad 6$

2 Models for Radionuclide Movement in the Human Body . . . 19

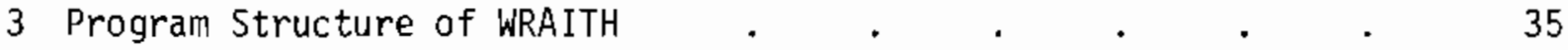

\section{TABLES}

1 Pasquill Standara Deviations for Horizontal Plume Spread . $\quad$. 4

2 Pasquill Standard Deviations for Vertical Plume Spread . . . 4

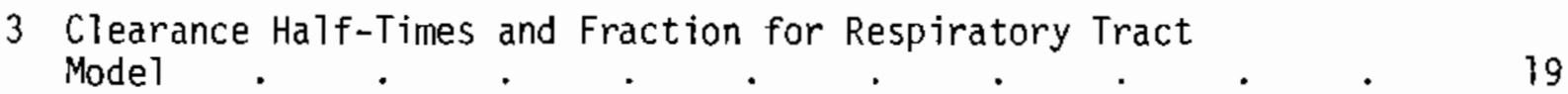

4 G. I. Tract Clearance Rates $\quad . \quad$. $\quad . \quad$. $\quad$. 25

5 Status of WRAITH Data Libraries . $\quad . \quad$. $\quad . \quad$. $\quad . \quad 44$ 



\section{WRAITH - A COMPUTER CODE FOR CALCULATING INTERNAL}

AND EXTERNAL DOSES RESULTING FROM AN

ATMOSPHERIC RELEASE OF RADIOACTIVE MATERIAL (a)

R. I. Scherpelz, F, J. Borst, ${ }^{(b)}$ and G. R. Hoenes

\section{INTRODUCTION}

The computer code WRAITH (Which Results Accompany Isotopic Iransport to Humans) was developed at the Pacific Northwest Laboratory for the U.S. Nuclear Regulatory Cornmission's study of Early Effects of Inhaled Radionuclides. WRAITH is specifically intended to determine doses for use as input to a dose response model. This model would predict mortality and morbidity in a population exposed to a cloud of radionuclides released during an accident at a nuclear facility. The release is assumed to occur during a short time interval, so that any exposure to the cloud will result in an acute dose. The source term (the quantities, in curies, of all radionuclides in the release) and meteorological conditions at the time of the release are assumed to be known. WRAITH then calculates doses which would be received by a reference man at each of a number of points directly downwind from the release.

WRAITH calculates the atmospheric movement of the released cloud using a bivariate straight-line Gaussian distribution model. The standard deviations are taken from Pasquill curves. Corrections may be applied for plume meander or building wake effects, for plume rise or for plume depletion by dry deposition.

Doses are calculated to three target organs: total body, red bone marrow, and the lungs. All important sources of radiation, both external and internal, are considered in evaluating the dose to each organ. The external dose contribution may be calculated either by assuming submersion in a plume of infinite dimensions or by a finite-plume calculation. Contributions from radiation emitted by nuclides in ten different source organs are considered

(a) Work on this project was performed for the U.S. Nuclear Regulatory Commission, Division of Safeguards, Fuel Cycle and Environmental Research, under DOE Contract DE-AC06-76RLO 1830.

(b) Present address: Ft. St. Vrain, Public Service Company of Colorado, Plattevilie, CO 80651. 
as irradiating the target organ. Movement of the material through the body is calculated using the Task Group Lung Model for the respiratory system and a four-segmented gastrointestinal tract model. Retention of radionuciides in other source organs is described by multiple exponential functions.

Dose commitments are calculated in units of rads, with separate values determined for high-LET and for low-LET radiation. The dose response model is not valid for high-LET radiation other than alphas. Therefore, WRAITH's high-LET dose calculation ignores the contributions of neutrons, spontaneous fission fragments and alpha recoil nuclei. If the user supplies a quality factor for alpha radiation, the summed dose commitments will be expressed in rems and in rads. Since the code was developed specifically for use with the dose response model, doses to only three organs are considered and acute inhalation is the only pathway for material to enter the body. 


\section{DESCRIPTION OF MATHEMATICAL MODELS}

\section{ATMOSPHERIC DISPERSION}

The atmospheric dispersion in WRAITH is calculated using a bivariate straight-line Gaussian distribution model, with standard deviations for lateral and vertical plume spread taken from Pasquill curves. Elevated and ground-level releases are handled differently: ground-level releases consider building wake effects and the effects of plume meander, while elevated releases may inciude plume rise correction factors. In a 11 cases, plume depletion by dry deposition may be calculated.

\section{Pasquill Standard Deviations for Plume Spread}

Material released from the accident site is assumed to travel at the average wind speed in a straight line from the release site to the receptor site.

The receptor site is assumed to be at ground level, on the plume centerline for ground-level releases, or directly below the plume centerline for elevated releases. Plume spread in the $x$-direction (parallel to the direction of the wind) is assumed to be negligible; thus, plume spread occurs only in the y direction (horizontaliy cross-wind) and z-direction (vertical). The plume spread is assumed to result in Gaussian distributions of material concentrations about the centerline in both the $y$ - and z-directions. The concentration distributions are described by the standard deviations, $\sigma_{y}$ and $\sigma_{z}$.

Vajues for $\sigma_{y}$ and $\sigma_{z}$ were obtained from the Pasquill curves. (1) These curves were plotted for each of six atmospheric stability classes, called A through $F$, where classes $A, B$ and $C$ are considered unstable, $D$ neutral, and $E$ and $F$ stable. The $\sigma$ values depend only on stability class and distance of plume trave1. Data from the curves were tabulated, and the data from the tables are stored in WRAITH. The code interpolates these table values to determine the $a$ values for each case. The a values in WRAITH are listed in Tables 1 and 2. 
TABLE 1. Pasquitl Standard Deviations for Horizontal Plume Spread

\begin{tabular}{|c|c|c|c|c|c|c|}
\hline \multirow{2}{*}{$\begin{array}{l}\text { Distance } \\
\text { (m) }\end{array}$} & \multicolumn{6}{|c|}{ Values of $\sigma y(m)$ for Pasquill Type } \\
\hline & $\bar{A}$ & $B$ & $\bar{C}$ & $D$ & $\mathrm{E}$ & $\bar{F}$ \\
\hline $\begin{array}{l}100 \\
150 \\
250 \\
350 \\
500 \\
700\end{array}$ & $\begin{array}{r}21 \\
32 \\
54 \\
75 \\
105 \\
142\end{array}$ & $\begin{array}{r}16 \\
24 \\
40 \\
55 \\
76 \\
106\end{array}$ & $\begin{array}{l}12 \\
17.5 \\
28.5 \\
40 \\
55 \\
76\end{array}$ & $\begin{array}{l}8 \\
12 \\
19.5 \\
26.5 \\
37 \\
51\end{array}$ & $\begin{array}{l}6 \\
9 \\
14.5 \\
20 \\
28 \\
37\end{array}$ & $\begin{array}{r}3.9 \\
6 \\
9.8 \\
13.5 \\
18.5 \\
25.5\end{array}$ \\
\hline $\begin{array}{l}1,000 \\
1,500 \\
2,500 \\
3,500 \\
5,000 \\
7,000\end{array}$ & $\begin{array}{r}200 \\
290 \\
450 \\
610 \\
830 \\
1,120\end{array}$ & $\begin{array}{l}148 \\
215 \\
340 \\
460 \\
630 \\
840\end{array}$ & $\begin{array}{l}106 \\
155 \\
240 \\
330 \\
450 \\
610\end{array}$ & $\begin{array}{r}72 \\
104 \\
160 \\
225 \\
310 \\
420\end{array}$ & $\begin{array}{r}52 \\
75 \\
120 \\
165 \\
220 \\
300\end{array}$ & $\begin{array}{r}36 \\
52 \\
81 \\
110 \\
153 \\
210\end{array}$ \\
\hline $\begin{array}{l}10,000 \\
15,000 \\
25,000 \\
35,000 \\
50,000 \\
70,000\end{array}$ & $\begin{array}{l}1,550 \\
2,200 \\
3,400 \\
4,500 \\
6,200 \\
8,200\end{array}$ & $\begin{array}{l}1,200 \\
1,680 \\
2,600 \\
3,500 \\
4,700 \\
6,400\end{array}$ & $\begin{array}{r}850 \\
1,200 \\
1,850 \\
2,500 \\
3,400 \\
4,700\end{array}$ & $\begin{array}{r}570 \\
710 \\
1,250 \\
1,700 \\
2,300 \\
3,000\end{array}$ & $\begin{array}{r}410 \\
570 \\
880 \\
1,180 \\
1,600 \\
2,100\end{array}$ & $\begin{array}{r}280 \\
400 \\
610 \\
820 \\
1,120 \\
1,480\end{array}$ \\
\hline 110,000 & 12,000 & 9,200 & 6,800 & 4,500 & 3,000 & 2,200 \\
\hline
\end{tabular}

TABLE 2. Pasquill Standard Deviations for Vertica] Plume Spread

\begin{tabular}{|c|c|c|c|c|c|c|}
\hline \multirow{2}{*}{$\begin{array}{l}\text { Distance } \\
(\mathrm{m})\end{array}$} & \multirow{2}{*}{\multicolumn{6}{|c|}{$\frac{\text { Values of } \sigma_{z}(\mathrm{~m}) \text { for Pasqu }}{\mathrm{C}}$}} \\
\hline & & & & & & \\
\hline $\begin{array}{l}100 \\
150 \\
250 \\
350 \\
500 \\
700\end{array}$ & $\begin{array}{l}15 \\
22.5 \\
43 \\
70 \\
135 \\
270\end{array}$ & $\begin{array}{l}10 \\
15 \\
25.5 \\
37 \\
57 \\
86\end{array}$ & $\begin{array}{l}7.8 \\
11 \\
17.5 \\
24 \\
34 \\
46\end{array}$ & $\begin{array}{l}4.7 \\
6.8 \\
10.5 \\
14 \\
19 \\
25\end{array}$ & $\begin{array}{l}3 \\
4.3 \\
7.1 \\
9.4 \\
13 \\
17\end{array}$ & $\begin{array}{l}1.4 \\
2.2 \\
4 \\
5.3 \\
7.6 \\
10\end{array}$ \\
\hline $\begin{array}{l}1,000 \\
1,500 \\
2,500 \\
3,500 \\
5,000 \\
7,000\end{array}$ & $\begin{array}{r}670 \\
2,000 \\
2,000 \\
2,000 \\
2,000 \\
2,000\end{array}$ & $\begin{array}{r}135 \\
240 \\
580 \\
1,200 \\
2,000 \\
2,000\end{array}$ & $\begin{array}{r}64 \\
90 \\
140 \\
190 \\
260 \\
340\end{array}$ & $\begin{array}{r}33 \\
43 \\
62 \\
76 \\
95 \\
115\end{array}$ & $\begin{array}{l}22 \\
29 \\
41 \\
50 \\
61 \\
72\end{array}$ & $\begin{array}{l}13.5 \\
17.7 \\
25 \\
30 \\
35 \\
41\end{array}$ \\
\hline $\begin{array}{l}10,000 \\
15,000 \\
25,000 \\
35,000 \\
50,000 \\
70,000\end{array}$ & $\begin{array}{l}2,000 \\
2,000 \\
2,000 \\
2,000 \\
2,000 \\
2,000\end{array}$ & $\begin{array}{l}2,000 \\
2,000 \\
2,000 \\
2,000 \\
2,000 \\
2,000\end{array}$ & $\begin{array}{r}440 \\
600 \\
880 \\
1,120 \\
1,440 \\
1,780\end{array}$ & $\begin{array}{l}140 \\
170 \\
220 \\
265 \\
320 \\
370\end{array}$ & $\begin{array}{r}84 \\
99 \\
117 \\
130 \\
140 \\
155\end{array}$ & $\begin{array}{l}47 \\
55 \\
64 \\
72 \\
79 \\
86\end{array}$ \\
\hline 110,000 & 2,000 & 2,000 & 2,000 & 480 & 175 & 97 \\
\hline
\end{tabular}




\section{Ground Level or Vent Releases}

When material is released at ground level or from building vents, the atmospheric dispersion calculation may include dilution due to wake effects from nearby buildings. Under stable atmospheric conditions with low windspeeds, the calculation may aiso include effects due to the plume meandering about the centeriine. When averaged over the time of the release, the plume is still described by a Gaussian distribution along the $y$ and $z$ axes, but meander will contribute to increased plume spread. Nuclear Regulatory Commission Regulatory Guide $1.145^{(2)}$ lists three equations which should be selectively used for calculating relative air concentrations:

$$
\begin{aligned}
& E / Q=\frac{1}{\bar{u}\left(\pi \sigma_{y} \sigma_{z}+A / 2\right)} \\
& E / Q=\frac{1}{\bar{u}\left(3 \pi \sigma_{y} \sigma_{z}\right)} \\
& E / Q=\frac{1}{\bar{u} \pi \Sigma_{y} \sigma_{z}}
\end{aligned}
$$

where: $E / Q=$ time-integrated relative air concentration $\left(\mathrm{sec} / \mathrm{m}^{3}\right)$,

$\bar{u} \quad=$ average windspeed at an evelation 10 meters above ground level $(\mathrm{m} / \mathrm{s})$,

$\sigma_{y} \quad=$ lateral (horizontal crosswind) plume $\operatorname{spread}(\mathrm{m})$,

$\sigma_{Z} \quad=$ vertical plume spread $(m)$,

A = smallest vertical plane cross-sectional area of the building near the release point $\left(\mathrm{m}^{2}\right)$,

$z_{y}=\left\{\begin{array}{l}M \sigma_{y} \text { for distances of } 800 \text { meters or less }(m) \\ (M-1) \text { oy } 800+\sigma_{y} \text { for distances greater than } 800 \text { meters }(m)\end{array}\right\}$,

oy800 $=$ oy at 800 meters, and

$\mathrm{M} \quad=$ determined from Figure 1 .

The notation for the relative air concentration is $E / Q$ rather than the more common $x / Q$ to identify it as a time-integrated quantity, integrated over the duration of the release. The total amount of material discharged in the release is multiplied by $E / Q$ to yield the time-integrated air concentration 
at the receptor point. This value is used to determine the total dose, rather than a dose rate.

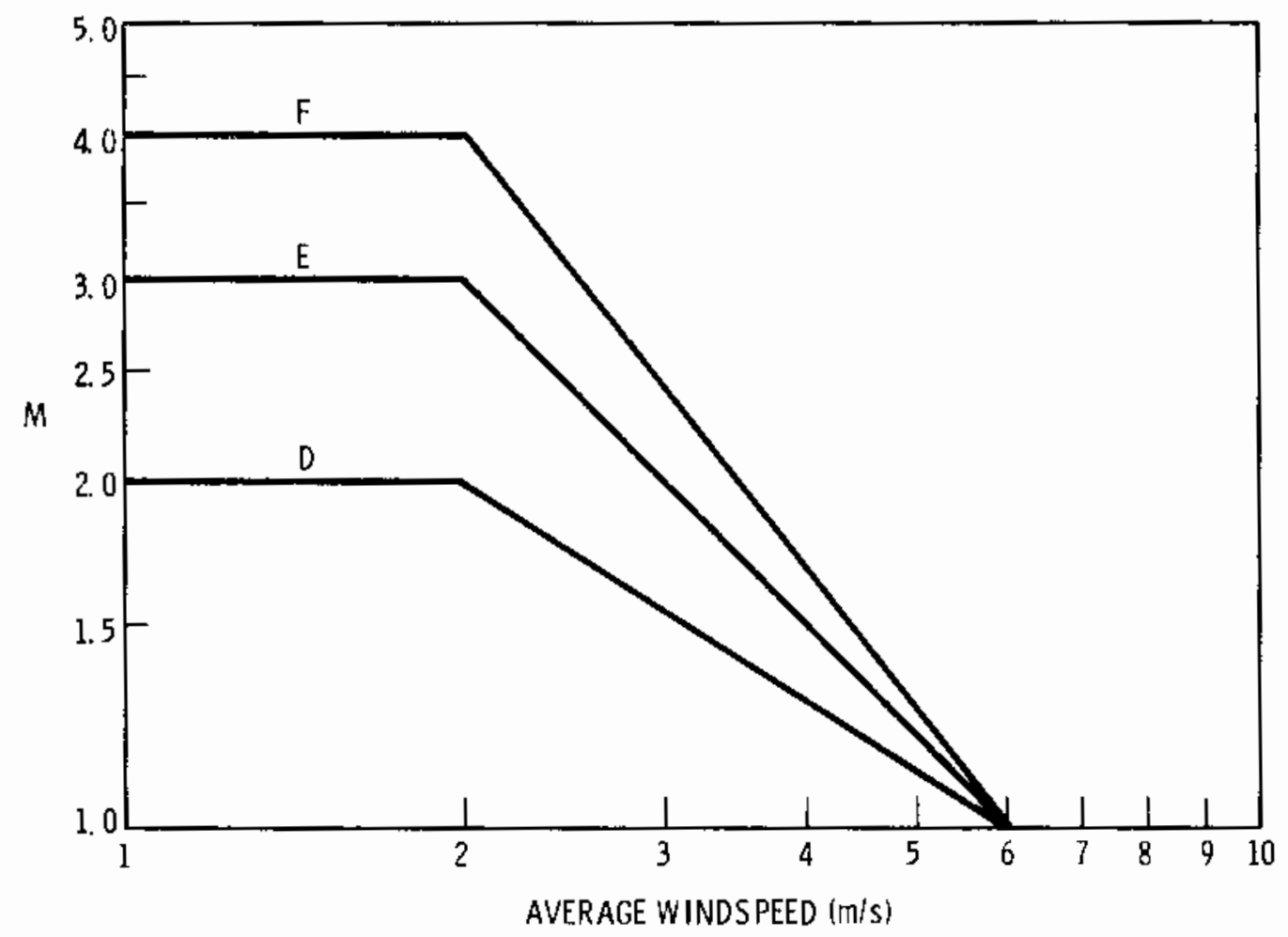

FIGURE 1. Determination of M, A Correction to Pasquill oy Vaiues

Values for $E / Q$ are calculated using Equations (1) and (2) for unstable stability classes or high windspeeds, or using Equations (1), (2) and (3) for stable classes with low windspeeds. The appropriate $E / Q$ value is then chosen using the following selection rules:

- For Pasquill classes A, B or C - or for $\mathbb{X}>6$ : The maximum of the two values determined by Equations (1) and (2) is the appropriate value of $E / Q$.

- For Pasquill classes $D, E$ or $F-$ and $\bar{u} \leq 6$ : The value of Equation (3) is compared to the maximum of Equations (1) and (2). The minimum of these two values is the appropriate $\mathrm{E} / \mathrm{Q}$ value. 


\section{Elevated Releases}

Atmospheric dispersion calculations due to releases from a stack elevated well above adjacent buildings use the following equation: ${ }^{(1)}$.

$$
E / Q=\frac{1}{\pi \bar{u} \sigma_{y} \sigma_{z}} \exp \left(\frac{-h_{e}{ }^{2}}{2 \sigma_{z}{ }^{2}}\right)
$$

where: $\bar{u}_{h}=$ average windspeed at release height $(\mathrm{m} / \mathrm{s})$,

$\begin{aligned} h_{e}= & \text { effective stack height }\langle m\rangle, \\ & h_{e}=h_{s}+\Delta h\end{aligned}$

$h_{S}=$ elevation of top of stack above ground level $(\mathrm{m})$,

$\Delta h=$ stack height correction due to piume rise $(m)$.

Two types of plume rise correction factors are commonly employed:

momentum-dominated plume rise and buoyancy-dominated plume rise. (3) The velocity of the effluent as it leaves the stack is responsible for the momentumdominated correction, while the heat content of the effluent determines the buoyancy-dominated correction. Either factor could act independently or in conjunction with the other.

Momentum-dominated plume rise is independent of atmospheric stability class and distance from the stack. It is calculated by: ${ }^{(4)}$

$$
\Delta h=1.5 \frac{v_{g} d}{\bar{u}_{h}}
$$

where: $V_{g}=$ velocity of effluent leaving the stack $(\mathrm{m} / \mathrm{s})$, and

$$
d=\text { inside diameter of top of the stack }(m) \text {. }
$$

Buoyancy-dominated plume rise depends on atmospheric conditions and distance from the stack, in addition to properties of the effluent. ${ }^{(5)}$ For Pasquill classes $A, B, C$ and $D$ :

$$
\Delta h=\frac{1.6 \mathrm{~F}^{1 / 3} \mathrm{X}^{2 / 3}}{\bar{u}_{\mathrm{h}}}
$$


where: $x=$ distance from the stack, or $10 \mathrm{~h}_{\mathrm{s}}$, whichever is larger $(\mathrm{m})$, $F \because\left\{\begin{array}{c}3.7 \times 10^{-5} Q_{h} \\ \text { or } \\ \frac{g V_{f}}{H}\left(1-\frac{T_{a}}{T_{s}}\right),\end{array}\right.$

$u_{h}=$ heat emission rate from the stack (cal/sec),

$g=9.8 \mathrm{~m} / \mathrm{s}^{2}$,

$V_{f}=$ effluent volume flow rate $\left(\mathrm{m}^{3} / \mathrm{s}\right)$,

$\mathrm{T}_{\mathrm{a}}=$ ambient air temperature at top of stack $\left({ }^{\circ} \mathrm{K}\right)$, and

$\mathrm{T}_{\mathrm{S}}=$ temperature of effluent as it leaves the stack $\left({ }^{\circ} \mathrm{K}\right)$.

Either expression may be used for $F$, depending on the available data. For Pasquili classes $E$ and $F$ :

$$
\begin{aligned}
\Delta h= & \frac{1.6 \mathrm{Fl}^{1 / 3} \mathrm{r}^{2 / 3}}{\bar{u}_{\mathrm{h}}}, \\
& \text { if } r \leq 2.4 \mathrm{u}_{\mathrm{h}} \mathrm{S}^{-1 / 2}
\end{aligned}
$$

where: $r=$ range (stack-to-receptor distance) $(m)$,

$$
S=\frac{g}{T_{a}}\left(\frac{\partial T_{a}}{\partial \underline{z}}+\Gamma\right)
$$

$\frac{\partial T_{a}}{\partial z}=$ vertical air temperature gradient $\left({ }^{\circ} \mathrm{K} / \mathrm{m}\right)$

$\Gamma=$ adiabatic lapse rate of the atmosphere

$$
=0.0098^{\circ} \mathrm{K} / \mathrm{m} \text {, and }
$$

$$
\begin{aligned}
\Delta h= & 2.9 \frac{F^{l / 3}}{\vec{u}_{h}} \\
& \text { if } r>2.4 \bar{u}_{h} S^{-1 / 2}
\end{aligned}
$$




\section{Plume Depletion by Dry Deposition}

Radioactive material may be lost from the plume when the plume touches vegetation or other surfaces. These processes may be included in the plume dispersion calculation by means of a correction factor for dry deposition. Nuclear Regulatory Commission Regulatory Guide $1 . \mathrm{m}^{(6)}$ recommends a model for plume depletion by dry deposition which depends on Pasquill stability class, elevation of release, and downwind distance of plume travel. The correction factors are expressed as the fraction of material released which remains in the plume. When the appropriate correction factor is multiplied by the material's concentration in air assuming no dry deposition, the effective plume concentration is obtained. Mathematical expressions fitting the curves in Regulatory Guide $1.111^{(6)}$ have been included in a subroutine in WRAITH. (7) The correction factor for each range, $D_{d}(r)$, can then be multiplied by $E / Q$ to calculate the corrected time-integrated relative air concentration:

$$
\frac{E(r)}{Q}=D_{d}(r) \frac{E^{\prime}(r)}{Q}
$$

$$
\text { where: } \begin{aligned}
\frac{E(r)}{Q}= & \text { time-integrated relative air concentration at range } r, \\
& \text { including appropriate correction factors }(\mathrm{sec} / \mathrm{m} 3), \\
& =1 \text { if no plume depletion is calculated } \\
& \text { or fraction of material remaining in plume at range } r \text { after } \\
& \text { plume depletion by dry deposition. }
\end{aligned}
$$

RADIOACTIVE DECAY AND PRODUCTION DURING TRANSIT

The concentrations of radioactive material in the plume can change due to radioactive decay while the plume is traveling from the release site to the receptor site. The quantity of a radionuclide present in the original release must be modified to account for radioactive decay and the production of daughter radionuclides during transit from the release point to each receptor point. This apparent quantity released can be multiplied by $E / Q$ to give the nuclide's air concentration at each receptor point. Thus,

$$
E_{j}(r)=Q_{j}{ }^{\prime}(r) \frac{E(r)}{Q}
$$


where: $E_{j}(r)=$ concentration of nuclide $i$ at range $r$ (curies-sec $/ \mathrm{m}^{3}$ ),

$$
\begin{aligned}
Q_{i}{ }^{\prime}(r)= & \text { activity of nuclide } i \text { in release, corrected for } \\
& \text { radioactive decay and production during transit } \\
& \text { to range } r \text { (curies). }
\end{aligned}
$$

For radionuclides present in the original release, $Q_{j}{ }^{\prime}(r)$ is found by:

$$
Q_{j}^{\prime}(r)=Q_{0 i} e^{-\lambda_{j}} t_{r}(r)
$$

where: $Q_{0 i}=$ quantity of nuclide $i$ in release $(C i)$,

$\lambda_{i}^{r} \quad=$ radioactive decay constant for nuc $] i d e ~ i\left(d^{-1}\right)$

$=\ln 2 / T_{i}^{r}$

$T_{j}^{r}=$ radioactive half-life of nuclide $i$ (d)

$t_{r}(r)=$ transit time for plume travel from release site to range $r(d)$

$$
=\frac{r}{86400 \bar{u}}
$$

If a radionuclide is a decay product of one or more radionuclides in the release, then its concentration must be adjusted for production from each parent nuclide in the release. For each parent $i$, production of each daughter, $j$, can be found by: ${ }^{(8)}$

$$
Q_{j}{ }^{\prime}(r)=Q_{0 i} \prod_{k=2}^{n}\left(\lambda_{k}^{r} f_{k}^{r}\right) \sum_{\substack { \ell=1 \\
\begin{subarray}{c}{p=1 \\
p \neq l{ \ell = 1 \\
\begin{subarray} { c } { p = 1 \\
p \neq l } }\end{subarray}}^{n} \frac{e^{-\lambda_{\ell}^{r}} t_{r}(r)}{n}
$$

where: $f_{k}^{r}=$ the fraction of nuclide $(k-1)$ decays which produce nuclide $k$, and subscripts obey the following rules:

Subscripts $k, l$ and $p$ refer to the nuclide which is the $k^{t h}$, $e^{\text {th }}$ or $p^{\text {th }}$ member of the chain path which leads from parent $i$ to daughter $j$. Daughter $j$ is the $n^{\text {th }}$ member of the chain path.

A radionuclide chain handled by WRAITH may have as many as eight members, and each daughter may have as many as two parents in the chain. Thus several paths may lead through the chain from a parent to a daughter, and Equation (12) must be performed for each chain path, sumning all the results 
to get the apparent release rate. If a nuclide is present in the release, then the results of Equation (11) and all necessary applications of Equation (12) must be sunmed to give $Q_{i}{ }^{\prime}$.

\section{EXTERNAL DOSE CALCULATION}

The component of the dose to a person at the receptor site which is due to radiation emitted by radionuclides outside the body is called the external dose. The external doses calculated by WRAITH are all $5 \mathrm{~cm}$ depth doses (doses to tissue by radiation attenuated by $5 \mathrm{~cm}$ of tissue). Since alpha and beta radiation do not significantly penetrate $5 \mathrm{~cm}$ of tissue, all the external dose calculations only consider gamma radiation. Two different methods of calculating external doses are available in WRAITH:

- submersion in a semi-infinite cloud, and

- numerical integration of doses over the finite plume volume.

Submersion in a Semi-Infinite Cloud

In a uniform infinite cloud of photon emitters, a small volume of air absorbs energy at the same rate as the rate of energy emission by that volume. Thus,

$$
\begin{aligned}
& \dot{D}_{\infty}=\frac{\left(1.6 \times 10^{-6}\right)\left(3.7 \times 10^{10}\right)}{(1220)(100)} x_{i} \sum_{g=1}^{n_{\gamma}} f_{\gamma g} E_{\gamma g} \\
& \dot{D}_{\infty}=0.485 x_{i} \sum_{g=1}^{n_{\gamma}} f_{\gamma g} E_{\gamma g}
\end{aligned}
$$

\footnotetext{
where: $\dot{D}_{\infty} \quad=$ dose rate to air at the center of a cloud containing nuclide $i(\mathrm{rad} / \mathrm{s})$,$$
x_{i}=\text { concentration of nuclide } i \text { in the cloud }\left(\mathrm{Ci} / \mathrm{m}^{3}\right) \text {, }
$$$$
n_{\gamma}=\text { number of photons emitted by nuclide } i \text {, }
$$$$
f_{\gamma g}=\text { abundance of the } g^{\text {th }} \text { photon, }
$$$$
E_{\gamma g}=\text { energy of the } g^{\text {th }} \text { photon }(\mathrm{MeV})
$$$$
1.6 \times 10^{-6}=\text { number of ergs per MeV }
$$ 
$3.7 \times 10^{10}=$ number of disintegrations $/ \mathrm{sec} / \mathrm{Ci}$,

$1220=$ density of dry air at $760 \mathrm{torr}, 290^{\circ} \mathrm{K}\left(\mathrm{g} / \mathrm{m}^{3}\right)$, and

$100=$ energy absorbed per gram of air/rad (erg/g-rad).

If the small volume absorbing energy is at ground level, it is exposed to only half of the plume (a semi-infinite plume). Equation (13) can therefore be used to find the dose rate to tissue at ground level by dividing by two and multiplying by the ratio of electron density in tissue to that in air:

$$
\begin{aligned}
& \dot{\mathrm{D}}_{\mathrm{ti}}=\frac{3}{i} \times 1.11 \times \dot{\mathrm{L}}_{\mathrm{sos}} \\
& \dot{\mathrm{D}}_{\mathrm{ti}}=0.269 x_{i} \sum_{\mathrm{g}=1}^{\mathrm{n}_{\gamma}} f_{\gamma g} \mathrm{E}_{\gamma \mathrm{g}}
\end{aligned}
$$

where: $\dot{\mathrm{b}}_{\mathrm{ti}}=$ dose rate to tissue at ground level ( $\left.\mathrm{rad} / \mathrm{s}\right)$, and

- 1.11 = ratio of electron density in tissue to that in air.

Integrating the dose rate over the total time of exposure to the cloud gives the total dose:

$$
\begin{aligned}
& D_{t i}(r)=\int_{0}^{t_{r}} D_{t i} d t=0.269 \sum_{g=1}^{n_{\gamma}} f_{\gamma g} E_{\gamma g} \int_{0}^{t_{r}} x_{i} d t \\
& D_{t i}(r)=0.269 E_{i}(r) \sum_{g=1}^{n_{Y}} f_{\gamma g} E_{\gamma g}
\end{aligned}
$$

where: $D_{t i}=$ the dose to tissue from gammas emitted by nuclide $i$ at range $r$ (rads), and

$t_{r}=$ total time of exposure to the cloud (sec).

To convert Equation (15) for use in a depth dose calculation, attenuation of the gammas by $5 \mathrm{~cm}$ of tissue must be included. Thus, Equation (15) is multiplied by an exponential attenuation factor and a buildup factor. WRAITH uses this equation in a slightly different form, calculating the product of a constant, the nuclide concentration, and its external dose factor: 


$$
D_{x i}(r)=\frac{1}{3.6 \times 10^{-6}} E_{i}(r) D_{f i}
$$

where: $D_{x j}(r)=$ external dose to tissue from gammas emitted by nuclide $i$ in a semi-infinite cloud, after attenuation by $5 \mathrm{~cm}$ of tissue (rad),

$D_{f i}=$ external dose factor for nuclide $i\left(\frac{m r a d \cdot m^{3}}{p C i \cdot h r}\right)$

$$
D_{f i}=9.695 \times 10^{-5} \sum_{g=1}^{n_{\gamma}} f_{\gamma g} E_{\gamma g}\left(1+\mu_{g} \Delta x\right) e^{-\mu_{g} \Delta x}
$$

where: $\mu_{g}=$ linear attenuation coefficient for gammas of energy $E_{\gamma g}$ in tissue $\left(\mathrm{cm}^{-1}\right)$, and

$$
\Delta x=5 \mathrm{~cm}
$$

The total external dose due to a semi-infinite plume containing a number of gamma-emitting nuclides is found by evaluating Equation (16) for each nuclide and summing al? the contributions.

\section{Exposure to a Plume of Finite Dimensions}

WRAITH finds the external dose resulting from exposure to a cloud of finite dimensions by performing a three-dimensional point kernel numerical integration. The dose rate due to a monoenergetic photon emitter in an incremental volume of air is:

$$
\dot{d}_{\gamma}=k_{k} \frac{E_{i} B_{a k}\left(r_{d}\right) E_{\gamma} \exp \left(-\mu_{a k} r_{d}\right)}{4 \pi r_{d}^{2}} d x d y d z
$$

\footnotetext{
where: $\dot{d}_{\gamma} \quad=$ incremental dose rate to tissue due to photonemitters in differential cloud volume, $\mathrm{dx} d y \mathrm{dz}$ ( $\mathrm{rad} / \mathrm{sec})$,

$k_{k}=$ dose conversion factor for energy groups $k$ $\left(\frac{\mathrm{rad} \cdot \mathrm{m}^{2}}{\mathrm{Ci}-\mathrm{sec}}\right.$ per MeV/dis),
} 


$$
\begin{aligned}
& k_{k}=\frac{\left(3.70 \times 10^{10}\right)\left(1.60 \times 10^{-6}\right)\left(10^{-4}\right)}{100}\left(\frac{\mu_{a}}{\rho}\right)_{k}, \\
& 3.70 \times 10^{10}=\text { number of } \mathrm{dis} / \mathrm{sec} / \mathrm{Ci} \\
& 1.60 \times 10^{-6}=\text { nunber of ergs } / \mathrm{MeV} \\
& 10^{4} \quad=\text { number of } \mathrm{m}^{2} / \mathrm{cm}^{2} \\
& 100=\text { number of ergs } / \mathrm{g} \cdot \mathrm{rad} \\
& B_{a k}\left(r_{d}\right)=\text { dose buildup factor in air for photons in energy } \\
& \text { group } k \text {, } \\
& B_{a k}\left(r_{d}\right)=1+A_{k} \mu_{a k} r_{d}+\alpha_{k}\left(\mu_{a k} r_{d}\right)^{2} \text {, } \\
& A_{k}, \alpha_{k}=\text { empirically-determined coefficients to fit buildup } \\
& \text { data from Berger (9), } \\
& E_{\gamma} \quad=\text { energy of photons (MeV/dis), } \\
& \mu_{a k}=\text { total linear attenuation coefficient in air } \\
& \text { for photons in energy group } k\left(\mathrm{~m}^{-1}\right) \text {, } \\
& r_{d} \quad=\text { distance from cloud volume to dose point }(m) \text {, and }
\end{aligned}
$$

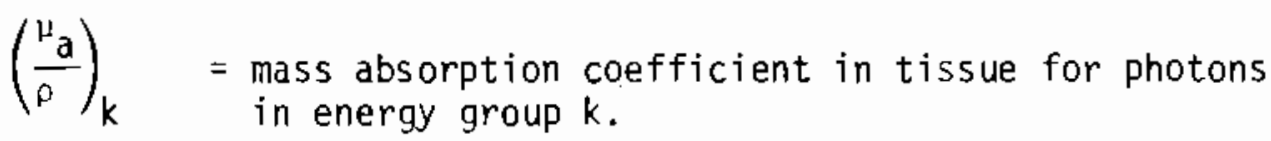

Since a number of variables in Equation (13) are energy dependent, WRAITH performs this external dose calculation using energy groups. The photon energy spectrum is divided into twelve energy groups, and a calculation is performed for each one individually.

The radionuclide concentrations in the differential cloud volumes are found using the following equation:

$$
E / Q=\frac{1}{2 \bar{u}_{h} \sigma_{y} \sigma_{z}} \exp \left(\frac{-(z-h e)^{2}}{2 \sigma_{z}^{2}}-\frac{y^{2}}{2 \sigma_{y}^{2}}\right)
$$

where: $z=$ height of the volume above plant grade $(\mathrm{m})$, and

$$
\begin{aligned}
y= & \text { horizontal distance of the volume from the plume } \\
& \text { center line }(\mathrm{m}) .
\end{aligned}
$$


The denominator of Equation (20) has a factor of two which does not appear in Equation (4). Equation (4) must include ground reflection, while a volume of air above the ground does not, resulting in a factor of two difference. In the event of ground level releases, the values of $\sigma_{y}$ and $\sigma_{z}$ are modified to reflect the effects of plume meander and building wake effects described by Equations (1), (2) and (3).

WRAITH uses Equations (18) and (20) to calculate an energy dose factor for each photon energy group. For each nuclide, the energy dose factors are combined with the energies of all photons, and the photon attenuation in $5 \mathrm{~cm}$ of tissue, to calculate the external $5-\mathrm{cm}$ dpeth dose for each nuclide.

$$
\begin{aligned}
D_{x i}(r)= & Q_{j}{ }^{\prime}(r) \sum_{k=1}^{12} D_{\gamma k}(r)\left(1+\mu_{k} \Delta x\right) e^{-\mu_{k} \Delta x} . \\
& \sum_{g=1}^{n_{\gamma k}} f_{k g} E_{\gamma k g}
\end{aligned}
$$

where: $\mu_{k}=$ linear attenuation coefficient for tissue, for gammas in the $k^{\text {th }}$ energy group $\left(\mathrm{cm}^{-1}\right)$,

$n_{\gamma k}=$ number of gammas emitted by nuclide $i$ in the $k^{\text {th }}$ energy group,

$f_{k g}=$ fraction of nuclide $i$ decays which produce the $g^{\text {th }}$ garma in the $k^{\text {th }}$ energy group,

$E_{\gamma k g}=$ energy of the $g^{\text {th }}$ gamma in the $k^{\text {th }}$ energy group (MeV), $D_{\gamma k}(r)=$ energy dose factor for gammas in the $k^{\text {th }}$ energy group at range $r(\mathrm{rad} / \mathrm{C} i-\mathrm{MeV})$.

$$
\begin{aligned}
D_{\gamma k}(r)= & \frac{1}{2 \pi \bar{u}_{h}} \int_{x_{1}}^{x_{2}} \int_{z_{1}}^{z_{2}} \frac{1}{\sigma_{z}} \exp \left(\frac{-(z-h e)^{2}}{2 \sigma_{z}{ }^{2}}\right) . \\
& \int_{y_{1}}^{y_{2}} \frac{B_{a k}\left(r_{d}\right)}{4 \pi r_{d}{ }^{2} \sigma_{y}} \exp \left(\frac{-y^{2}}{2 \sigma_{y}{ }^{2}}\right) \exp \left(-\mu_{a k} r_{d}\right) k_{k} d x d y d z
\end{aligned}
$$


The integrations in Equation (22) are performed numerically, using repeated applications of an eight-point polynomial integration formula (Bode's rule). The limits of integration are usually selected as three standard deviations from the dose point. (10)

\section{INTERNAL DOSE CALCULATIONS}

WRAITH calculates doses to three "target organs" .

- tota? body,

- red bone marrow, and

- pulmonary region of the iungs.

All doses are calculated in rads, with separate determinations of doses for low-LET radiation (photons and electrons) and high-LET radiation (alphas).

\section{Cross-Organ Doses}

For the internal dose calculation, each target organ is considered to be irradiated by radiation enitted by radionuclides in nine "source organs":

- red bone marrow

- pulmonary region of the lungs

- liver

- stomach

- small intestine
- upper large intestine

- lower large intestine

- respiratory lymphatic system

- other

The source organ called "other" is included to account for radionuclides in the body which are not present in any of the other source organs. The quantity of any radionuclide not included in the other eight source organs is assumed to be evenly distributed through the entire body.

The basic equation used to evaluate the dose commitment due to radionuclide $n$ in source organ $X$ irradiating target organ $Y$ is: $(11,12)$

$$
D_{n}(Y+X)=S_{n}(Y+X) \int_{0}^{t c} A_{X n}(t) d t
$$


where: $D_{n}(Y \in X)=$ dose commitment over time period tc to target organ $Y$ from radionuclide $n$ in source organ $X$ (rads),

$$
\begin{aligned}
S_{n}(Y \leftarrow X)= & \text { S-factor for radionuclide } n \text { in source organ } X \\
& \text { irradiating target organ } Y(\text { rad } / \mu C i \text {-days }), \text { and }
\end{aligned}
$$

$$
\int_{0}^{t c} A_{x_{n}}(t) d t=\begin{aligned}
& \text { activity-residence time of nuclide } n \text { in } \\
& \text { organ } x \text { over time period tc ( } \mu C i \text {-days). }
\end{aligned}
$$

The dose calculated in Equation (23) is due to nuclide $n$ alone, and assumes no contribution from any daughters of nuclide $n$. Thus, the activityresidence time for each of $n$ 's daughters must also be calculated and multiplied by the appropriate $S$-factor to obtain the total dose to an organ resulting from the introduction of $n$ into the organ.

The general formulation for calculating an S-factor for radiation type $p$ is:

$$
S_{p}(Y+X)=51.15 \sum_{m=1}^{n_{p}} f_{p m} E_{p m} \phi p r i \quad(Y<X)
$$

where:

$$
\begin{aligned}
& 51.15=\left(\frac{g \cdot r a d}{M e V}\right) \times\left(\frac{\text { disintegrations }}{\mu C i-\text { day }}\right) \text {, } \\
& n_{p} \quad=\text { number of different particles of type } p \text { emitted, } \\
& f_{p m} \quad=\text { intensity of the } m^{\text {th }} \text { particle of type } p \text { (number) } \\
& \text { disintegration), } \\
& \mathrm{E}_{\mathrm{pm}} \quad=\text { energy of the } m^{\text {th }} \text { particle of type } \mathrm{p} \text { (MeV), and } \\
& \phi_{\mathrm{pm}}(Y+X)=\text { specific absorbed fraction: fraction of energy } \\
& \text { emitted from source organ } X \text { absorbed in target } \\
& \text { organ } Y \text {, per gram of } Y\left(g^{-1}\right) \text {. }
\end{aligned}
$$

The low-LET S-factor for a nuclide is found by summing the S-factors for photons, betas and other electrons emitted by that nuclide. The high-LET S-factors include contributions on ly from alphas.

Respiratory Tract Model

Since the internal dosimetry calculation in WRAITH deals with particles which are introduced to the body by acute inhalation, the model for the respiratory tract is of prime importance. The model used in WRAITH is 
adapted from the report of the ICRP-II Task Group on Lung Dynamics. (13) This model was developed for radionuclides which are attached to particles, and other radionuclides, such as noble gases, are treated differently.

The respiratory tract in the Task Group Lung Model is divided into three regions: the nasopharyngeal region $(N-P)$, tracheobronchial region $(T-B)$, and the pulmonary region $(P)$. The radionuclides introduced into the respiratory system are assumed to be attached to particles whose sizes are log-norma $11 y$ distributed about an activity median aerodynamic diameter (AMAD). The AMAD of a group of inhaled particles determines the fraction of the group which is deposited in each of the three regions. These deposition fractions are identified in the calculations as:

$D_{3}=$ the fraction of inhaled particles deposited in the $N-P$ region,

$D_{4}=$ the fraction of inhaled particles deposited in the $T-B$ region, and

$D_{5}=$ the fraction of inhaled particles deposited in the $P$ region.

Accepted values of $D_{3}, D_{4}$, and $D_{5}$ for $A M A D$ values ranging from 0.1 to 20 microns are presented in Figure VI-8.6 of the USNRC's Reactor Safety Study. WRAITH evaluates the fractions using equations which fit these curves from a subroutine of the code INREM-II. (15)

Material deposited in the three respiratory compartments is assumed to leave the compartments via specific pathways. One pathway from each compartment leads directly to the bloodstream. Either one or two pathways from each respiratory compartment lead to the stomach, which is the first segment of the four-segmented gastro-intestinal tract model. One pathway from the pulmonary region leads to the iymphatic system. Additional pathways lead from the G.I. tract and from the iymphatic system to the blood. Figure 2 illustrates the compartments and pathways of the biological model used in WRAITH.

The chemical form of the inhaled radionuclides and the physical form of the particles they are attached to determine the clearance of the radionuclides from the respiratory compartments. WRAITH allows any mixture of 
TABLE 3. Clearance Half-Times and Fractions for

\begin{tabular}{|c|c|c|c|c|c|c|c|}
\hline \multirow{3}{*}{ COMPARTMENT } & \multirow[b]{3}{*}{$\begin{array}{l}\text { Path- } \\
\text { way } j\end{array}$} & \multicolumn{6}{|c|}{ CLEARANCE CLASS } \\
\hline & & & & $\bar{W}$ & & $Y$ & \\
\hline & & $T_{j}^{b}$ & $f_{j}^{b}$ & $r_{j}^{b}$ & $f_{j}^{b}$ & $T_{j}^{b}$ & $F^{b}$ \\
\hline NP & $\begin{array}{l}a \\
b\end{array}$ & $\begin{array}{l}0.01 \\
0.01\end{array}$ & $\begin{array}{l}0.5 \\
0.5\end{array}$ & $\begin{array}{l}0.01 \\
0.40\end{array}$ & $\begin{array}{l}0.1 \\
0.9\end{array}$ & $\begin{array}{l}0.01 \\
0.4\end{array}$ & $\begin{array}{l}0.01 \\
0.99\end{array}$ \\
\hline$T B$ & $\begin{array}{l}c \\
d\end{array}$ & $\begin{array}{l}0.01 \\
0.2\end{array}$ & $\begin{array}{l}0.95 \\
0.05\end{array}$ & $\begin{array}{l}0.01 \\
0.2\end{array}$ & $\begin{array}{l}0.5 \\
0.5\end{array}$ & $\begin{array}{l}0.01 \\
0.2\end{array}$ & $\begin{array}{l}0.01 \\
0.99\end{array}$ \\
\hline$P$ & $\begin{array}{l}e \\
f \\
g \\
h\end{array}$ & $\begin{array}{c}0.5 \\
-- \\
-- \\
0.5\end{array}$ & $\begin{array}{l}0.8 \\
0.0 \\
0.0 \\
0.2\end{array}$ & $\begin{array}{c}50 \\
1 \\
50 \\
50\end{array}$ & $\begin{array}{l}0.15 \\
0.4 \\
0.4 \\
0.05\end{array}$ & $\begin{array}{r}500 \\
1 \\
500 \\
500\end{array}$ & $\begin{array}{l}0.05 \\
0.4 \\
0.4 \\
0.15\end{array}$ \\
\hline Lymph & $i$ & 0.5 & 1 & 50 & 1 & 1000 & 0.9 \\
\hline
\end{tabular}

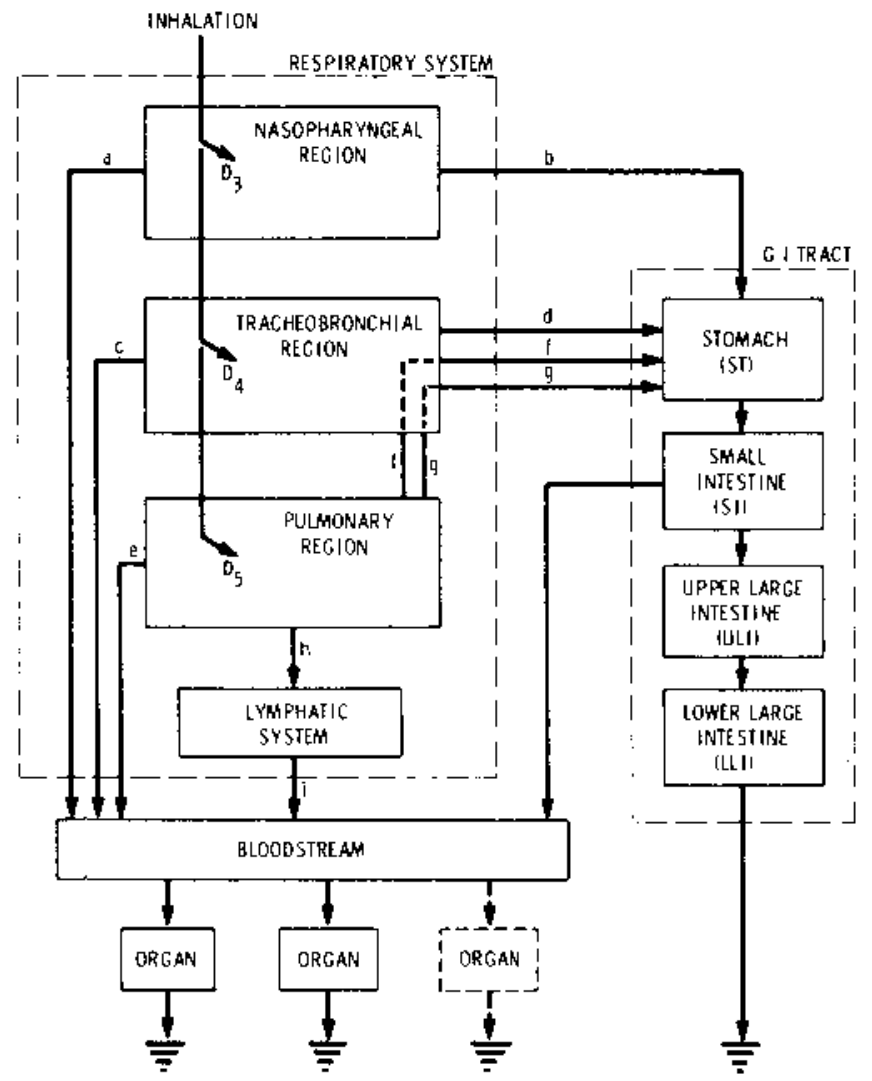

FIGURE 2. Models for Radionuclide Movement in the Human Body 
three clearance classes for each radionuclide: D class, li class or $Y$ class. The class of a radionuclide determines the allocation of the radionuclides deposited in any respiratory compartment among the various pathways leading from each compartment. The clearance class (sometimes called "solubility class") also determines the rate at which a radionuclide clears the compartment. The clearance rate is described by a biological half time. Clearance rates and allocation fractions for all pathways are compiled in Table 3 . It is assumed that any daughters of an inhaled nuclide share their parents'. clearance class for the respiratory tract calculation.

The material leaving a respiratory compartment by a given pathway is assumed to clear exponentialiy, with the pathway's biological half time determining the exponential decay. This biological exponential clearance is coupled with the nuclide's radioactive exponential decay. The governing differential equation for this process is:

$$
\frac{d N_{i j}(t)}{d t}=-\lambda_{i}^{r} N_{i j}(t)-\lambda_{j}^{b} N_{i j}(t)
$$

where: $N_{i j}(t)=$ the number of atoms of radionuclide $i$ present in a respiratory compartment at time $t$ which will clear the compartment by pathway $j$,

$\lambda_{i}^{r} \quad=$ radioactive decay rate constant for nuclide $i$ $\left(\right.$ day $\left.^{-1}\right)$,

$\lambda_{j}^{b}=\underset{(\text { biological decay rate constant for pathway } j}{ } j$

$\lambda_{j}^{b} \quad=\frac{\ln 2}{T_{j}^{b}}$, and

$\mathrm{T}_{\mathrm{j}}^{\mathrm{b}} \quad=$ clearance half time for pathway $\mathrm{j}$ (days).

To calculate the activity of an inhaled nuclide in a respiratory compartment, $c$, at some time $t$ days after inhalation, Equation (25) is solved, and summed over all pathways leading from compartment $c$ :

$$
a_{1 c}(t)=Q_{n I} D_{c} \sum_{j=1}^{j_{c}} f_{j} e^{-\lambda_{n j} t}
$$



where: $\begin{aligned} Q_{1 c}(t)= & \text { activity of nuclide } n \text { in compartment } c \text { at } \\ & \text { time } t(\mu C i),\end{aligned}$

$$
\begin{aligned}
& \left.Q_{n I}=\text { quantity of nuclide } n \text { inhaled ( } \mu_{C} \mathrm{C}\right) \text {, } \\
& Q_{n}=E_{n} \times \dot{B} \text {, } \\
& \dot{\mathrm{B}}=\text { ventilation rate }\left(\mathrm{cm}^{3} / \mathrm{sec}\right) \text {, } \\
& D_{C}=\text { fraction of inhaled material depesited in } \\
& j_{c}=\text { number of pathways leading from compartment } \mathrm{c} \text {, } \\
& f_{j}=\text { fraction of material in compartment } c \text { clearing } \\
& \text { via pathway } j \text {, } \\
& \lambda_{n j}=\text { effective decay constant for nuclide } n \text { in } \\
& \text { compartment } j[\text { sum of radicinete and bio- } \\
& \text { logical decay constants](day-i), and } \\
& \lambda_{n j}=\lambda_{n}^{r}+\lambda_{j}^{b} \text {. }
\end{aligned}
$$

The subscript " 1 " is redundant in Equation (26) stane it refers to the first nuclide in nuclide $n$ 's decay chain, which is nuclide $n$ itself. Subsequent equations will drop the " $n$ " subscrist on $Q_{I}$, assuming that $Q_{I}$ always refers to the quantity of a specific nuc? ide inhaled. Members of this nuc1 ide's decay chain will then be referenced by an integer subscript.

An important step in evaluating internal doses is determining the activity-residence time in each source organ. When a nuclide is inhaled, the activity-residence time for the nuclide and each of its progeny nuclides is evaluated in al1 source organs. These calculations use equations with complex exponential expressions similar to the Bateman equation [Equation (12)] but with many more exponentials. The equations used in WRAITH for internal dosimetry use a shorthand for these exponential expressions: (17)

$$
E_{i}=\exp \left(-\lambda_{j} t\right)
$$

The subscript on the $E$ corresponds to the subscript on the $\lambda$. The $E$ notation omits the $t$ in the expression, and it also omits any superscript which may be on the $\lambda$. The time value and any appropriate $\lambda$ subscript should be obvious in each equation. 
For a more complex exponential expression with two or more exponential terms, the E notation uses one subscript (or one set of subscripts) for each $\lambda$, with the subscripts separated by commas. When more than one subscript is used on the $E$, it indicates a combination of two $E$ 's of the next lower level of complexity:

$$
E_{i, j}=\frac{E_{i}-E_{j}}{\lambda_{j}-\lambda_{i}}=\frac{e^{-\lambda_{j} t}-e^{-\lambda_{j} t}}{\lambda_{j}-\lambda_{i}}
$$

and

$$
E_{i, j, k, \ell}=\frac{E_{i, j, k}-E_{j, k, \ell}}{\lambda_{\ell}-\lambda_{i}}
$$

In internal dosimetry equations, one subscript is often insufficient for completely specifying one decay constant. Therefore, the equations which follow usually use one or two subscripts and a superscript:

$$
\lambda_{n c}=\lambda_{n}^{r}+\lambda_{c}^{b}
$$

where: $r$ : indicates a radioactive decay constant for nuclide $n$

$b$ : indicates a biological clearance constant in body compartment $c$

: no superscript indicates an effective decay constant (sum of biological and radioactive).

When a large number of subscripts would make the $E$ notation cumbersome, or when the number of subscripts may be variable, a shorthand for the subscript list uses the symbol $\Pi$.

$$
E_{i=1} i c=E_{1 c}, 2 c, 3 c, \ldots n c
$$

The $\lambda^{\prime}$ 's used in this expression could be $\lambda_{1 c}, \lambda_{2 c}, \lambda_{3 c}, \ldots \lambda_{n c}$, for the effective decay constants of the $i$ th nuclide in compartment $c$. Thus, using the notation of Equation (27), we could rewrite Equation (12) as:

$$
Q_{j}^{\prime}(r)=Q_{0 j} \prod_{k=2}^{n}\left(\lambda_{k}^{r} f_{k}^{r}\right) E \prod_{\substack{n \ell \\ \ell=1}}^{n}
$$


If the exponential expression is integrated over a time period, $t$, the notation is:

$$
\int_{E_{a, b, c}}=\int_{0}^{t} E_{a, b, c} d t
$$

The activity-residence time in respiratory compartment $c$ for the $n^{\text {th }}$ daughter of an inhaled nuclide is:

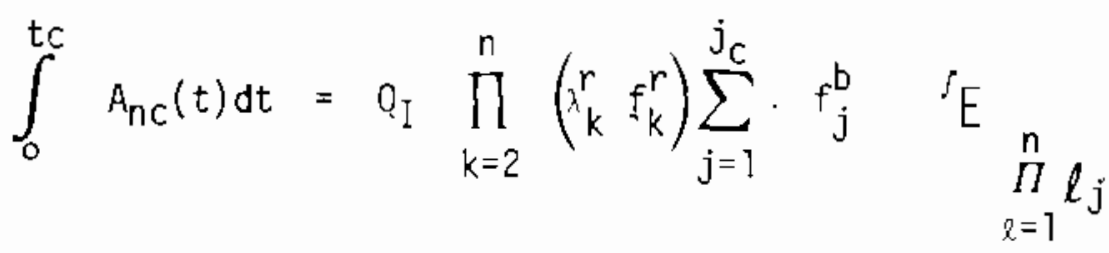

Use of the E notation simplifies the solution of the differential equations for radionuclide movement in the body and provides a simple and efficient method of programming the equations. Using the exact solutions to the differential equations eliminates the need for numerical integration techniques which can be time consuming and approximate.

\section{Respiratory Lymphatic System}

Material which clears the puimonary region through the respiratory lymphatic system is held in the lymph nodes for a period of time and, therefore, the lymphatic system is used as a source organ. For material in clearance classes $D$ and $W, f_{j}=1$, so that all material entering the lymph system eventualiy passes to the bloodstream. For $Y$ class material, only $90 \%$ of the material in the lymph nodes clears to the bloodstream. The other $10 \%$ remains in the $1 y$ mph nodes indefinitely, subject only to radioactive decay. The equation for the activity-residence time of the $n^{\text {th }}$ daughter of an inhaled nuclide in the respiratory iymphatic system is: 


$$
\int_{0}^{t c} A_{n L}(t) d t=Q_{I} D_{5} \prod_{k=2}^{n}\left(\lambda_{k}^{r} f_{k}^{r}\right) f_{h} \lambda b_{h} .
$$

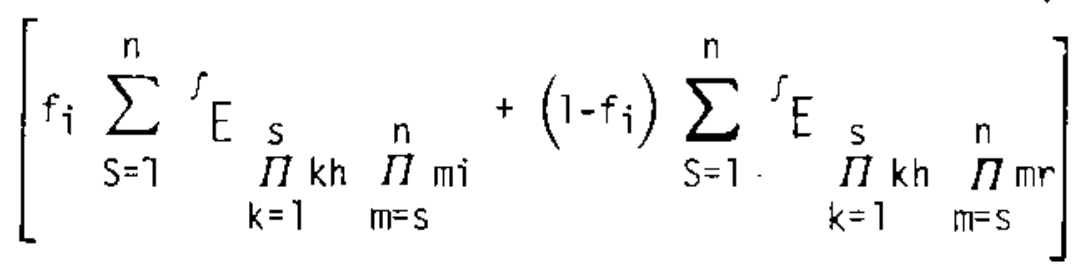

\section{where: $\int_{0}^{t c} A_{n L}(t) d t=\begin{aligned} & \text { activity-residence time of the } n^{\text {th }} \text { in the Tymphter } \\ & (\mu C i-\text { days }) .\end{aligned}$}

In the E notation, subscripts $h$ and $i$ refer to pathways $h$ and $i$ while subscript $r$ refers to radioactive decay:

$$
\begin{aligned}
& \lambda_{\mathrm{kh}}=\lambda_{h}^{b}+\lambda_{k}^{r} \\
& \lambda_{m i}=\lambda_{i}^{b}+\lambda_{m}^{r} \\
& \lambda_{m r}=\lambda_{m}^{r}
\end{aligned}
$$

A complication arises for $D$ and $W$ class material since $h_{h}^{b}=\underbrace{b}_{i}$. Thus, evaluating the E terms in Equation (30) using the method of Equation (27) would result in an undefined result due to a zero in the denominator. This problem can be solved by looking at the definition given for $E_{12}$ in reference 17 and working out the special case where $\lambda_{1}=\lambda_{2} \cdot(18)$ The result is:

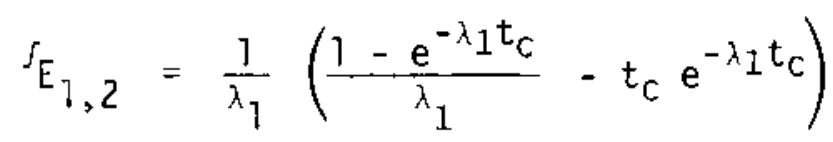

This value can be used in obtaining any higher order $E$ terms using the form of Equation (27).

\section{Gastrointestinal Tract Model}

The model used by WRAITH for the G.I. tract is a four-compartment mode?. (19) The four compartments and their relationship to the respiratory tract are illustrated in Figure 2. All material is assumed to enter the 
G.I. tract via pathways $b, d, f$ and $g, a 11$ leading to the stomach. The clearance rates for material passing from one G.I. compartment to the next are assumed to be independent of the material's isotopic content and solubility class. All material in the stomach is assumed to either pass into the small intestine or experience radioactive decay in the stomach. The small intestine is the only segment contributing material to the bloodstream and $f_{1 n}$, the fraction of nuclide $n$ in the small intestine which is absorbed into the bloodstream, is a property of the nuclide. The rest of the material in the sma 11 intestine either passes to the upper large intestine or decays in the small intestine. The only biological clearance path from the upper large intestine leads to the lower large intestine, and material leaving the lower large intestine is assumed to leave the body. The decay rates for movement between G.I. segments are listed in Table 4.

TABLE 4. G.I. Tract Clearance Rates

\begin{tabular}{ccc}
$\begin{array}{c}\text { Compartment Material } \\
\text { Exits }\end{array}$ & $\begin{array}{c}\text { Compartment Material } \\
\text { Enters }\end{array}$ & $\begin{array}{c}\text { Biological Clearance } \\
\text { Rate (d }\end{array}$ - $)$ \\
\cline { 1 - 1 } ST & SI & 24 \\
SI & ULI & 6 \\
ULI & LLI & 1.85 \\
LLI & --- & 1.0
\end{tabular}

The biological clearance rate for material absorbed from the sma 11 intestine into the bloodstream is determined by the fraction of material which moves by that path:

$$
\lambda_{(S I-a b) n}^{b}=\stackrel{b}{S I}_{S I} \frac{f_{1 n}}{\left(1-f_{1 n}\right)}
$$

where: $\quad \stackrel{b}{\lambda}(\mathrm{SI}-\mathrm{ab}) \mathrm{n}=$ biological clearance rate for nuclide $n$ absorbed from the small intestine into the bloodstream $\left(\mathrm{d}^{-1}\right)$

${ }^{b}{ }_{S I} \quad=$ biological clearance rate for material passing from the small intestine to the upper large intestine $\left(\mathrm{d}^{-1}\right)$

$f_{1 n}=$ fraction of nuclide $n$ absorbed from the small intestine into the bloodstream. 
The activity residence times in the four G.I. compartments for the $n^{\text {th }}$ daughter of an inhaled nuclide follow:

STOMACH:

$$
\begin{aligned}
& \int_{0}^{t c} A_{n S T}(t) d t=Q_{I} \prod_{k=2}^{n}\left(\lambda_{k}^{r} f_{k}^{r}\right) \sum_{j} D_{C j} f_{j} \lambda_{j}^{b} \cdot
\end{aligned}
$$

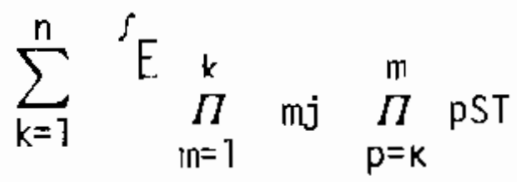

SMALL INTESTINE:

$$
\begin{aligned}
& \text { tc } \\
& \int_{0}^{\mathrm{tc}} A_{n S I}(t) d t=Q_{I} \lambda_{S I}^{\mathrm{b}} \stackrel{\prod_{k=2}^{n}}{n}\left(\lambda_{k}^{r} f_{k}^{r}\right) \sum_{j} D_{c j} f_{j} \lambda_{j}^{b} \cdot
\end{aligned}
$$

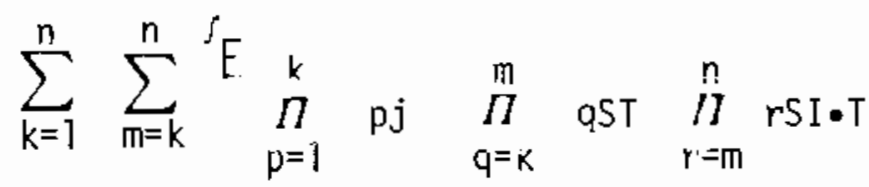

UPPER LARGE INTESTINE:

$$
\begin{aligned}
& \int_{0}^{\mathrm{tc}} A_{n U L I}(t) d t=Q_{I} \lambda_{S I}^{\mathrm{b}} \lambda_{S T}^{\mathrm{b}} \underset{\mathrm{k}=2}{n}\left(\lambda_{k}^{r} f_{k}^{r}\right) \sum_{j} D_{c j} f_{j} \lambda_{j}^{b} \cdot
\end{aligned}
$$

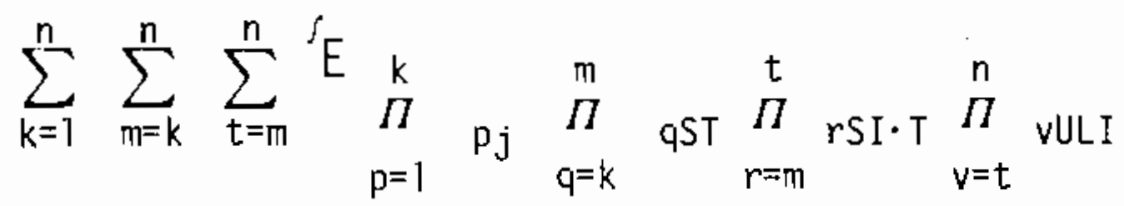




\section{LOWER LARGE INTESTINE:}

$$
\begin{aligned}
& \int_{0}^{t c} A_{n L L I}(t) d t=Q_{I} \lambda_{U L I}^{b} \lambda_{S I}^{b} \lambda_{S T}^{b} \underset{k=2}{\stackrel{n}{n}}\left(\lambda_{k}^{r} f_{k}^{r}\right) . \\
& \sum_{j} D_{C j} f_{j} \lambda_{j}^{b} \sum_{k=1}^{n} \sum_{m=k}^{n} \sum_{t=m}^{n} \sum_{y=t}^{n}
\end{aligned}
$$

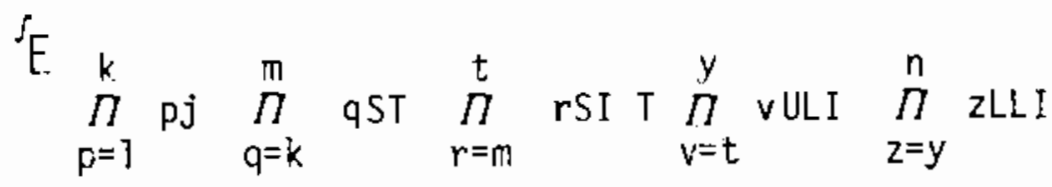

where: $\quad \int_{0}^{t c} A_{n S T}(t) d t=\begin{aligned} & \text { activity-residence time of the } n \\ & \text { daughter in the stomach over dose } \\ & \text { commitment time period } t_{C}(\mu C i-\text { days) }\end{aligned}$

$$
\int_{0}^{t c} A_{n S I}(t) d t=\begin{aligned}
& \text { activity-residence time of the } n^{\text {th }} \\
& \text { daughter in the small intestine over } \\
& t_{c}(\mu C i-\text { days })
\end{aligned}
$$$$
\int_{0}^{t c} A_{n U L I}(t) d t=\begin{aligned}
& \text { activity-residence } t \text { ime of the } n \\
& \text { daughter in the upper large intestine } \\
& \text { over } t_{c}(\mu C i \text {-days })
\end{aligned}
$$$$
\begin{aligned}
\int_{0}^{t c} A_{n L L I}(t) d t= & \begin{array}{l}
\text { activity-residence time of the } n \text {th } \\
\text { daughter in the lower large intestine } \\
\text { over } t_{C}(\mathrm{C} i \text {-days })
\end{array} \\
= & \text { the } j \text { th pathway from the respiratory } \\
& \text { tract, including pathways } b, d \text {, } f \text { and } g \\
= & \text { the lung deposition fraction in the } \\
D_{C j} & \text { compartment which includes pathway } j \\
\lambda_{j} & \text { the biological decay constant for pathway } j
\end{aligned}
$$ 


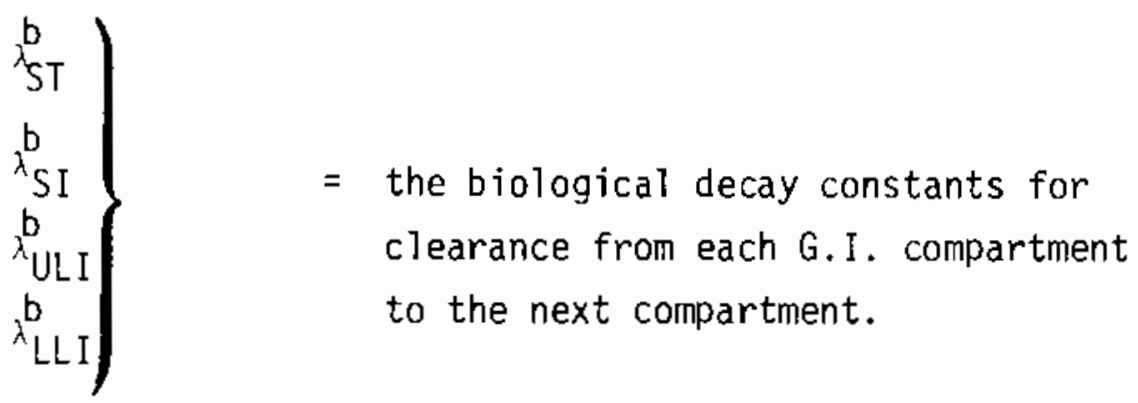

Each $E$ term is integrated over time period $t_{C}$. The $E$ terms use the following decay constants:

$$
\begin{aligned}
& \lambda_{m j}=\lambda_{j}^{b}+\lambda_{m}^{r} \\
& \lambda_{\text {pST }}=\lambda_{S T}^{b}+\lambda_{p}^{r} \\
& \lambda_{r S I T}=\lambda_{S I}^{b}+\lambda_{S I}^{b}\left(\frac{f_{1 r}}{1-f_{I r}}\right)+\lambda_{r}^{r} \\
& \lambda_{\text {VULI }}=\lambda_{U L I}^{b}+\lambda_{V}^{r} \\
& \lambda_{\text {ZLLI }}=\lambda_{\text {LLI }}^{b}+\lambda_{z}^{r}
\end{aligned}
$$

\section{Other Source Organs}

Three body compartments outside the respiratory system, G.I. tract and respiratory lymphatic system are treated as source organs: red bone marrow, liver, and "other". All material reaching each of these organs is assumed to come from the bloodstream. Three types of pathways lead from the respiratory system to the bloodstream: direct pathways (a, c,e); pathways through the G.I. tract (b, $d, f, g)$; and a pathway through the lymphatic system ( $h$ ). Material is assumed to move through the bloodstream instantaneously, but several different biological half times can be used to describe the clearance of a nuclide from an organ. Thus, a nuclide's activity in an organ can be described by a multiple exponential retention fraction:

$$
A_{\text {no }}(t)=A_{\text {no }}(0) \sum_{W=1}^{W_{\text {no }}} c_{\text {now }} \exp \left(-\lambda_{\text {now }} t\right)
$$


where: $A_{n o}(t)=$ activity of nuclide in organ 0 at time $t,(\mu C i)$

$A_{n o}(0)=$ activity of nuclide $n$ ir organ 0 at time $0,(\mu \mathrm{Ci})$

$w_{\text {no }}=$ number of terms of nuclide $n$ 's retention function for organ 0

$C_{\text {now }}=w^{\text {th }}$ coefficient of the retention function for nuclide $n$ in organ o

$\lambda_{\text {now }}=w^{\text {th }}$ decay constant for nuclide $n$ in organ 0 , $\left(d^{-1}\right)$

$\lambda_{\text {now }}=\lambda_{\text {ow }}^{\mathrm{b}}+\lambda_{\mathrm{n}}^{r}$

In many cases, the coefficients for a retention function are a1l positive and sum to one. In these cases, the coefficients can be viewed as allocating fractions, determining the fractional quantity of a nuclide clearing the organ by the coefficient's associated decay constant. In other cases, however, some coefficients are negative and the sum may be different than one. For all organs, material leaving the organ is assumed to simultaneously leave the body. Any daughters of ar. inhaled nuclide are considered to be independent of their parent after entering the bloodstream. Thus, a daughter's own retention function and other metabolic parameters are used for each of the organs.

In calculating the movement of material passing through the G.I. tract to other organs, the material is assumed to experience no delay in the G.I. tract. Since clearance half-times are one hour for the stomach and about four hours for the small intestine, this delay is negligible with respect to a 50-year dose commitment time period. With this assumption, the equations for the activity-residence times of material in other organs all follow the same format for pathways (a) through $(g)$ : 


$$
\begin{aligned}
& \int_{0}^{t c} A_{n o}(t) d t=Q_{I} \prod_{k=2}^{n}\left(\lambda_{k}^{r} f_{k}^{r}\right) \sum_{j=a}^{g} D_{c j} f_{j} \lambda_{j}^{b} \\
& \sum_{Z_{n=1}}^{Z_{n o}} c_{n o z_{n}}\{F_{n}^{b} f_{E} \underbrace{n}_{t=1} t j, n_{n} \\
& +\sum_{Z(n-1)=1}^{Z} c(n-1) o z(n-1) \triangleleft F_{(n-1)}^{b} \int_{t=1}^{f_{E-1}^{n}} t j,(n-1) o z_{n} \\
& +. .+\sum_{z_{s=1}}^{Z_{s o}} \operatorname{csoz}_{s}\left[F_{s}^{b} \int_{E} \underset{t=1}{s} t j \prod_{u=s}^{n} u_{0} z_{u}\right. \\
& +\ldots+\sum_{Z_{2=1}}^{Z_{20}} c_{2 o z_{2}}\left(F_{2}^{b} E_{1 j, 2 j}, \prod_{u=2}^{n} \mathrm{Uoz}_{u}\right.
\end{aligned}
$$

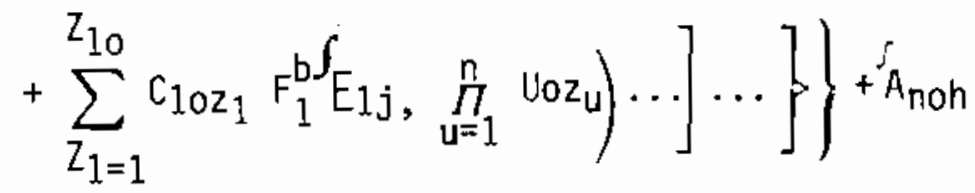

where:

$$
\begin{aligned}
& \int_{0}^{t c} A_{n o}(t) d t=\begin{array}{l}
\text { activity-residence time of the nth daughter in organ } 0 \\
\text { over time period } t_{C} .
\end{array} \\
& I_{A_{\text {noh }}}=\begin{array}{l}
\text { contribution to the activity-residence time of the } n t h \\
\text { daughter in organ o by the material passing through the } \\
\text { lymph system. }
\end{array}
\end{aligned}
$$




$$
\begin{aligned}
& F_{i}^{b}=\left\{\begin{array}{l}
f_{20 i} \text { for pathways } a, c \text {, and } e . \\
f_{20 i} \cdot f_{1 i} \text { for pathways } b, d, f, \text { and } g .
\end{array}\right. \\
& f_{20 i}=\text { fraction of the ith nuclide transferred from the bloodstream } \\
& \text { to organ } 0 .
\end{aligned}
$$

Material moving via pathway $h$ to an organ is held up in one more compartment than material moving via the other seven pathways. Thus the equation for this pathway is somewhat more complex than equation (38):

$$
\begin{aligned}
& s_{A_{n o h}}=Q_{I} \prod_{k=2}^{n} f_{k}^{r} \lambda_{k}^{r} \quad D_{5} f_{h} \lambda_{h}^{b} f_{i} \lambda_{i}^{b} \sum_{z_{n}=1}^{z_{n o}} c_{n o z} \quad\left\{f_{20} \sum_{q=1}^{n}\right.
\end{aligned}
$$

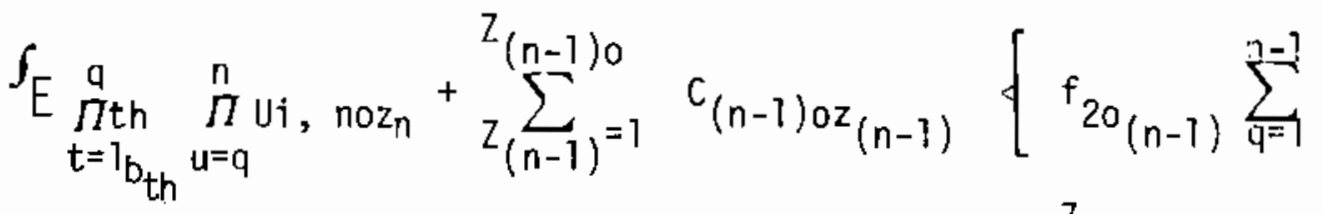

$$
\begin{aligned}
& \int_{E} \underset{t=1}{q} \underset{u=q}{n-1} \prod_{u i},(n-1) o z_{(n-1)}, \operatorname{noz}_{n}+\ldots \sum_{Z_{s=1}}^{Z_{s o}}{ }^{c}{ }_{s o z}
\end{aligned}
$$

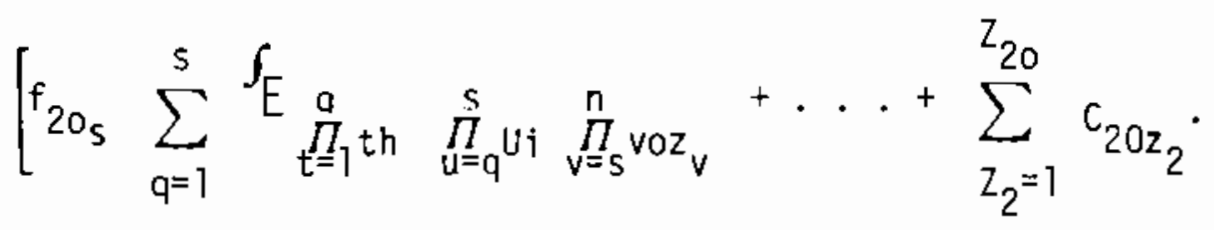

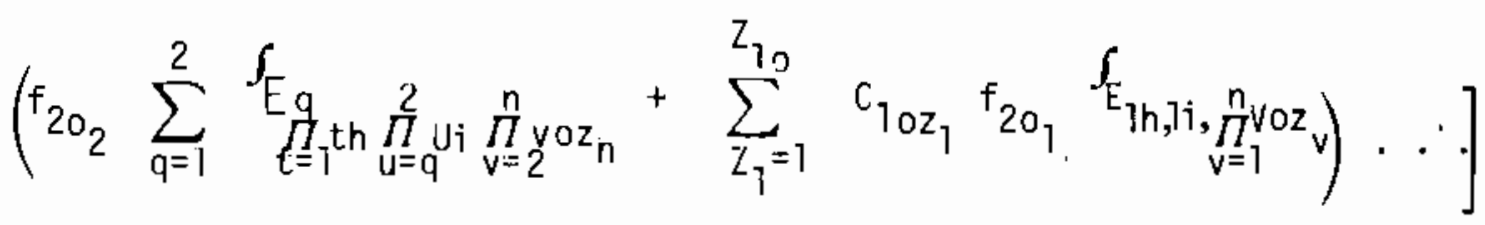

$$
\begin{aligned}
& \cdots\}
\end{aligned}
$$




\section{THYROID:}

For certain nuclides, the thryoid is treated as a tenth source organ. Equations (38) and (39) are used to calculate the activity-residence times of the nuclides in the thyroid. The thyroid calculations are performed only for the radioisotopes of iodine and the jodine daughters. Thus the thyroid is not generally considered as a source organ.

In situations where a radionuclide's daughter is an isotope of a noble gas, the noble gas nuclides produced in an organ by radioactive decay are assumed to clear that organ with a two-hour half life. None of the noble gas radionuclides are considered to be transferred to an organ without such decay, however. Thus $f_{20 i}=0$ for all organs 0 when $i$ is an isotope of a noble gas.

\section{Internal Doses Calculated Using Dose Factors}

For a number of nuclides, the Task Group Lung Model is a poor model for describing the movement of inhaled radionuclides. Since isotopes of noble gases enter the lungs as a gas, they are not attached to individual particles. Thus the mode] for the respiratory system cannot be used to determine deposition fractions for the three compartments or allocation fractions for the eight clearance pathways. WRAITH calculates internal doses due to inhaled noble gases by assuming that the lungs are filled with the noble gas at the same concentration as it occurs in the air outside the body. The noble gas experiences no movement from the lungs to any other part of the body.

$$
\dot{D}_{\ell n}(t)=\left(3.7 \times 10^{10}\right)\left(1.60 \times 10^{-8}\right) x_{n}(t) \frac{V_{C}}{m_{l}} \epsilon
$$

where:

$$
\begin{array}{ll}
\dot{D}_{\ell n}(t) & =\text { dose rate to the lung from nuclide } n(\mathrm{rad} / \mathrm{s}) \\
V_{c} & =\text { vital capacity of the lung }\left(\mathrm{m}^{3}\right) \\
m_{\ell} & =\text { mass of the lungs }(g) \\
\epsilon & =\text { energy/disintegration deposited in the lungs (MeV/dis) }
\end{array}
$$


Integrating the dose rate over the time of the release gives the total dose to the lungs:

$$
\begin{aligned}
& D_{2 n}=2.371 \times 10^{-3} \epsilon E_{n}(r) \\
& D_{\ell n}=D_{f \ell n} E_{n}(r)
\end{aligned}
$$

where:

$$
\begin{aligned}
E_{n}(r)= & \text { time-integrated air concentration of nuclide } n \text { in the air } \\
& \text { at the dose point }\left(\mathrm{Ci} \cdot \mathrm{s} / \mathrm{m}^{3}\right) \\
D_{\mathrm{f} \ell \mathrm{n}}= & \text { inhalation dose factor for nuclide } \mathrm{n}, \text { to the lung } \\
& \left(\mathrm{rad} \cdot \mathrm{m}^{3} / \mathrm{Ci} \cdot \mathrm{s}\right)
\end{aligned}
$$

Since contaminated air in the lungs would act as a source organ irradiating other target organs, doses to the other target organs can be calculated by using appropriate dose factors. The dose factor for dose to another organ can be found by adjusting the lung dose factor by the ratio of the appropriate S-factors. 
WRAITH is a computer program written in ASCII FORTRAN for the UNIVAC $1100 / 44$. The code is designed to be run interactively from a demand terminal, with a detailed output routed to a high-speed printer. Running the program requires about $72 \mathrm{~K}$ words of core on the UNIVAC. A simple WRAITH case wi1T require less than 10 seconds of execution time on the UNIVAC, but the more time-consuming options could require execution times of 30 or 40 seconds per range.

PROGRAM STRUCTURE

WRAITH contains a main program, 16 subroutines and five functions. Most of the calculations are performed in the subroutines. The main program controls the program execution, calling the subroutines in the appropriate order. There is only one common block, so that data is transferred between subroutines, program main, and functions through the common block, through function or subroutine arguments, or using both means. Figure 3 is an illustration of the subroutines and functions in WRAITH, and it shows the relationships between the units. A vertical line connecting program units indicates that the lower unit is called by the upper unit. A listing of the computer code is oresented in Appendix $A$. Appendix $B$ is a dictionary of the variables in the common block.

\section{DESCRIPTION OF SUBROUTINES}

MAIN reads data from the interactive terminal, calls subroutines and prints much of the output. MAIN performs some of the calculations, but most calculations are performed in other subroutines. MAIN prints out the Q.A. page, nuclide decay chain data, lung deposition fractions, external dose table, activity-residence time tables, cross-organ dose tables and summed dose tables.

SECOND is a system-supplied subroutine to display the run's execution time.

DATE is a system-supplied subroutine to display the date of the run.

TIME is a system-supplied subroutine to display the time of day of the run. 
FIGURE 3. Program Structure of WRAITH

$\stackrel{\omega}{w}$

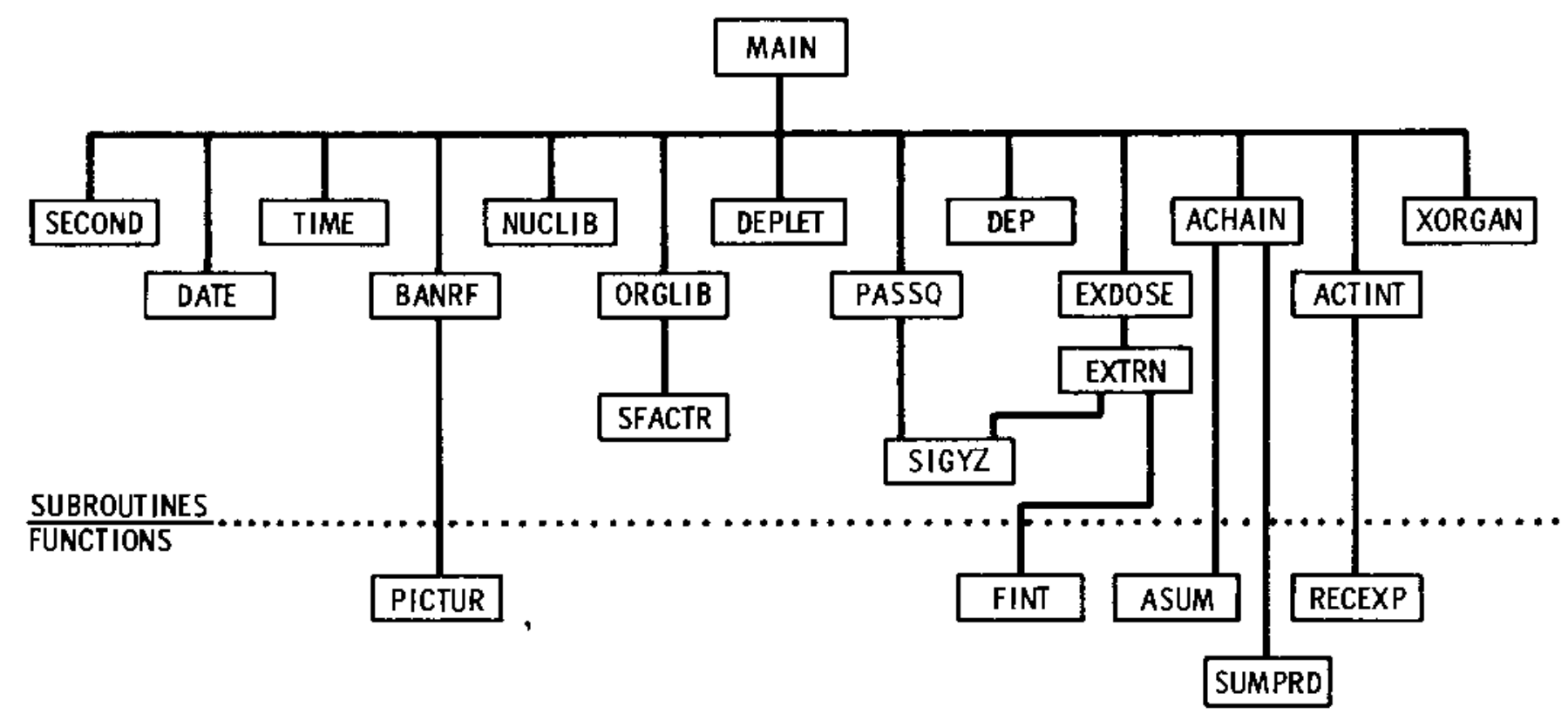


BANRF is a system-supplied subroutine to print the banner on the title page. Function PICTUR is called by BANRF.

NUCLIB reads data from the radionuclide data library on logical unit 10. It identifies radionuclides requested by the run, and selects all daughters of the requested nuclides, and stores all necessary half lives.

ORGLIB reads organ data from logical unit 12 for a 11 requested nuclides and their daughters. It also reads submersion dose factors, S-factors, and inhalation dose factors from logical unit 14. ORGLIB prints out tables of organ data, S-factors and inhalation dose factors.

SFACTR is called by ORGLIB to calculate some of the low-LET S-factors.

DEPLET calculates plume depletion by dry deposition. It calculates the fraction of material remaining in the plume at each distance (not considering the effect of radioactive decay).

PASSQ controls the atmospheric dispersion calculation. It calculates $E / Q$ for each distance, and prints the atmospheric calculation summary table.

SIGYZ is called by PASSQ. It interpolates stored data to calculate $\sigma_{y}$ and $\sigma_{z}$. It also calculates plume rise correction factors.

DEP calculates the lung deposition fractions $\mathrm{D}_{3}, \mathrm{D}_{4}$, and $\mathrm{D}_{5}$.

EXCOSE controls the external dose calculation. It selects the appropriate type of external dose factor for each range, then prints the table of external dose factors.

EXTRN is called by EXDOSE. EXTRN calculates external dose factors for overhead plumes and plumes of finite dimensions. It calls SIGYZ to get the necessary values of $\sigma_{y}$ and $\sigma_{z}$. It also uses function FINT.

ACHAIN calculates the radioactive decay of the nuclides in the release during the time of transit from the release point to the dose point. It calls functions ASUM and SUMPRD.

ACTINT calculates activity-residence times. It finds these values for the lungs; respiratory lymph; the organs "other," red marrow, and liver; and the four G.I. compartments. There are separate activity-residence time 
calculations for requested nuclides and for daughters of requested nuclides. The activity-residence times in the thyroid are also calculated for iodine nuclides and daughters. ACTINT calls function RECEXP to evaluate the "E" terms which occur in equations (28) through (39).

XORGAN multiples activity-residence times by $\$$-factors to get cross-organ dose conmitments. It also multiplies inhalation dose factors by nuclide concentrations in the air to get inhalation doses for noble gases. All contributions to the dose for each organ are summed up to give the summed doses to each organ.

\section{DATA LIBRARIES}

Three libraries contain data used by WRAITH: NUCDAT, the nuclide data 1ibrary; ORGDAT, the organ data 1ibrary; and SFACTR, the library of S-factors and inhalation and external dose factors.

Nuclide Data Library

NUCDAT contains radioactive half lives and decay chain data for a 11 nuclides. It contains two sections, one for a 11 nuclides, and one for nuclides used in the thyroid calculation. In the first section, there is one line of data for each nuclide, containing the following:

Columns Format Variable

$\begin{array}{lll}1-2 & \text { A2 } & \text { Element abbreviation } \\ 3-8 & \text { A6 } & \text { Atomic mass number, and "M" if isomeric state } \\ 9-18 & \text { E10.4 } & \text { Radioactive half life (days) } \\ 19-20 & \text { I2 } & \text { Chain member identification number } \\ 21-22 & \text { I2 } & \text { Identification number of first parent } \\ 23-29 & \text { F7.4 } & \text { Fraction of first parent decays which produce this nuclide } \\ 30-31 & \text { I2 } & \text { Identification number of second parent } \\ 32-38 & \text { F7.4 } & \text { Fraction of second parent decays which produce this nuclide }\end{array}$

Following the last nuclide's entry is a line with a zero in column 20.

The second section of the nuclide data library contains information on the iodine isotopes and their daughters, used in the thyroid calculation. The format of each line is identical to the nuclide entries in the previous section, except for the chain member identification. The ID numbers in the thyroid section run from 1 to 13 and are not reset to $I$ at the beginining of each decay chain. 
The final line of the nuclide data file has a number less than zero in columns $9-18$.

Organ Data Library

ORGDAT contains data describing the movement of radionuclides in the body. This library also contains two sections, one for all nuclides and the other for onty iodine and iodine daughters in the thyroid.

The first line of the organ data library contains the title (Format A128). For each nuclide there are at least seven lines of data:

Line 1:

\begin{tabular}{|c|c|c|}
\hline 1umn & Format & Variabie \\
\hline $1-2$ & & \multirow{9}{*}{ 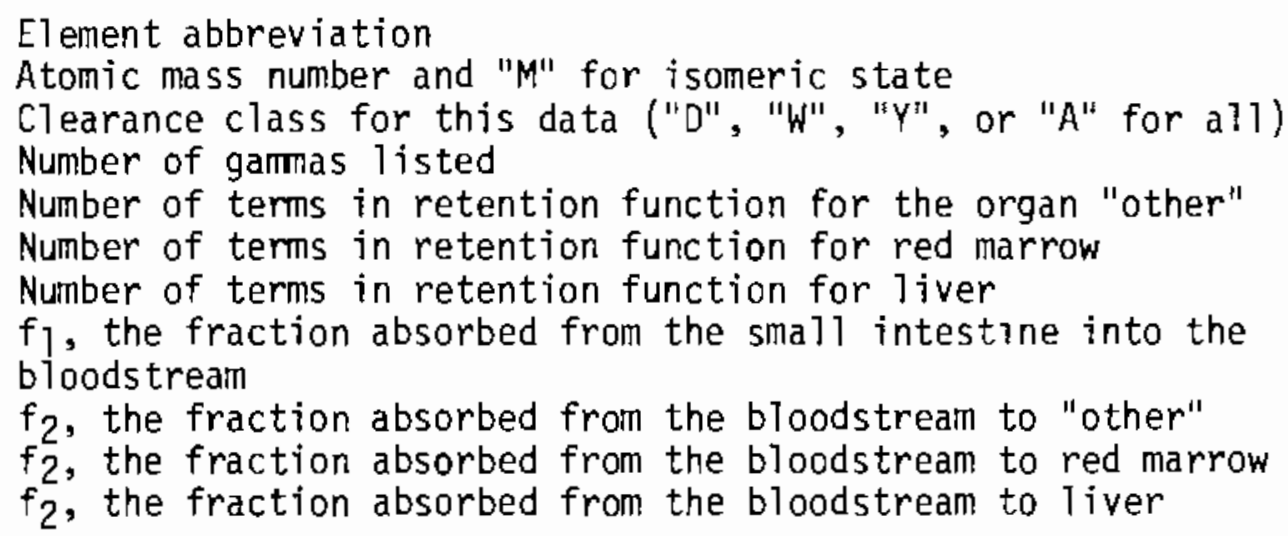 } \\
\hline $3-8$ & & \\
\hline & & \\
\hline $10-14$ & & \\
\hline & & \\
\hline & & \\
\hline & & \\
\hline & $\mathrm{E} 1$ & \\
\hline & & \\
\hline \multicolumn{3}{|l|}{ Line 2: } \\
\hline olumn & Forma & Variable \\
\hline $1-10$ & El & \multirow{6}{*}{$\begin{array}{l}\text { Biological half life for first term of retention function for } \\
\text { "other" (days) } \\
\text { Biological half life for second term of retention function } \\
\text { for "other" (days) } \\
\text { Biological half life for third term of retention function } \\
\text { for "other" (days) } \\
\text { Biological half life for fourth term of retention function } \\
\text { for "other" (days) } \\
\text { Biological half life for fifth term of retention function } \\
\text { for "other" (days) } \\
\text { Biological half life for sixth term of retention function } \\
\text { for "other" (days) }\end{array}$} \\
\hline $11-20$ & E10.4 & \\
\hline $21-30$ & El0. 4 & \\
\hline $31-40$ & ET0.4 & \\
\hline $41-50$ & E10.4 & \\
\hline $51-60$ & E10.4 & \\
\hline
\end{tabular}


Line 3:

\begin{tabular}{rrl} 
Column & Format & \multicolumn{1}{c}{ Variable } \\
$1-10$ & E10.4 & $\begin{array}{l}\text { Fractional coefficient for first term of retention function } \\
\text { for "other" }\end{array}$ \\
$11-20$ & E10.4 & $\begin{array}{l}\text { Fractional coefficient for second term of retention function } \\
\text { for "other" }\end{array}$ \\
$31-30$ & E10.4 & $\begin{array}{l}\text { Fractional coefficient for third term of retention function } \\
\text { for "other" }\end{array}$ \\
$41-40$ & E10.4 & $\begin{array}{l}\text { Fractional coefficient for fourth term of retention function } \\
\text { for "other" }\end{array}$ \\
$51-60$ & E10.4 & $\begin{array}{l}\text { Fractional coefficient for fifth term of retention function } \\
\text { for "other" } \\
\text { Fractional coefficient for sixth term of retention function } \\
\text { for "other" }\end{array}$
\end{tabular}

Line 4:

Biological half lives for retention function for red marrow (format identical to line 2).

Line 5:

Fractional coefficients for retention functions for red marrow (format identical to line 3 ).

Line 6:

Biological half lives for retention function for liver (format identical to line 2).

Line 7:

Fractional coefficients for retention function for liver (format identical to line 3).

Line 8: (if necessary)

$\begin{array}{rrll}\text { Column } & \text { Format } & \text { Variable } \\ 17-10 & \text { E10.4 } & \text { Energy of first gamma (MeV) } \\ 11-20 & \text { E10.4 } & \text { Fractional yield of first gamma } \\ 21-30 & \text { E10.4 } & \text { Energy of second gamma (MeV) } \\ 31-40 & \text { E10.4 } & \text { Fractional yield of second gamma } \\ 41-50 & \text { E10.4 } & \text { Energy of third gamma (MeV) } \\ 51-60 & \text { E10.4 } & \text { Fractional yield of third gamma } \\ 61-70 & \text { E10.4 } & \text { Energy of fourth gamma (MeV) } \\ 71-80 & \text { E10.4 } & \text { Fractional yield of fourth gammla } \\ 81-90 & \text { E10.4 } & \text { Energy of fifth gamma (MeV) } \\ 91-100 & \text { E10.4 } & \text { Fractional yield of fifth gamma }\end{array}$




\section{Lines 9-27: (if necessary)}

Energies and fractional yields for a 11 remaining gammas are entered here, in formats identical to 1 ine 8 . The total number of gammas entered is indicated in the first line of the nuclide's organ data entry. This number may be as high as 200 .

Following organ data for the last nuclide, there is a negative integer in columns i0-14.

The second section contains biological data for the thyroid. The first line of this section is a title.

Line 2:

\begin{tabular}{|c|c|c|}
\hline Column & Format & Variable \\
\hline $1-5$ & I5 & Number of terms in retention function for $I$ in \\
\hline $6 \sim 18$ & & Number of terms in retention function for $x_{e}$ in thyroid \\
\hline $11-75$ & & Number of terms in retention function for $x_{e}$ in thyroid \\
\hline $76-20$ & & Number of terms in retention function for $\mathrm{Cs}$ in thyroid \\
\hline & ElC & $\begin{array}{l}\text { Fraction of iodine absorbed from the bloodstream to the } \\
\text { thyroid }\end{array}$ \\
\hline
\end{tabular}

Line 3:

\begin{tabular}{rrl} 
Column & Format & \multicolumn{1}{c}{ Variable } \\
$11-70$ & E10.4 & $\begin{array}{l}\text { Biological ha1f life for first term of retention function } \\
\text { for I in thyroid (days) }\end{array}$ \\
21-60 & E10.4 & $\begin{array}{l}\text { Biological half 1ife for second term of retention function } \\
\text { for I in thyroid (days) } \\
\text { Could be used for successive terms if the retention function } \\
\text { were modified }\end{array}$
\end{tabular}

Line 4:

\begin{tabular}{|c|c|c|}
\hline olumn & Format & Variable \\
\hline $1-10$ & El0.4 & nt for firs \\
\hline $11-20$ & E]0.4 & $\begin{array}{l}\text { Fractional coefficient for } \\
\text { for I in thyroid }\end{array}$ \\
\hline $1-t$ & 10 & $\begin{array}{l}\text { Could be used for successive terms if the retention function } \\
\text { were modified }\end{array}$ \\
\hline
\end{tabular}

Line 5:

Biological half Tives for the retention function for $x e$ in the thyroid (format identical to line 3 ). 
Line 6:

Fractional coefficients for the retention function for $\mathrm{Xe}$ in the thyroid (format identical to line 4).

Line 7 and 8 are identical to 1 ines 5 and 6 , since some jodine isotopes have two xenon daughters.

Line 9:

Biological half lives for the retention function for $C s$ in the thyroid (format identical to line 3 ).

Line 10:

Fractional coefficients for the retention function for CS in the thyroid (fomat identical to line 4 ).

The final line of the organ data library has a negative integer in columns $9-15$.

S-Factor Data Library

SFACTR contains S-factors, external dose factors, and inhalation dose factors for noble gases. There are three sections to S-factor: one for all nuclides, one for S-factors with thyroid as the source organ, and one for noble gas inhalation dose factors.

The first line is the 1ibrary title, format AT28.

For each nuclide, Section 1 contains three 1 ines:

Line 1:

Column Format Variable

1-2 A2 Element abbreviation

3-8 A6 Atomic mass number and " $M$ " for isomeric state

9-18 El0.4 External dose factor for five-centimeter depth dose (mrad.m $\mathrm{m}^{3} / \mathrm{pC} \mathrm{i}-\mathrm{hr}$ )

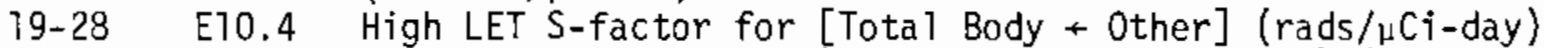

29-38 E10.4 High-LET S-factor for [Red Marrow \& Red Marrow] (rads/uCi-day)

39-48 ET0.4 High-LET S-factor for [Lung $\&$ Lung] (rads/uCi-day)

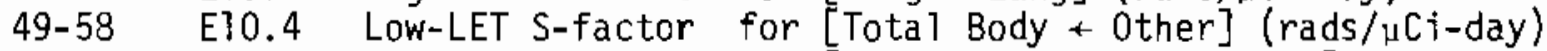

59-68 E10.4 Low-LET S-factor for [Red Marrow 4 Red Marrow] (rads/uCi-day)

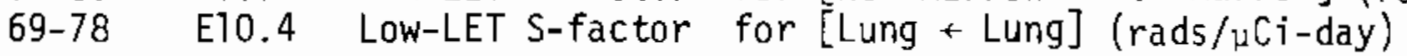


Line 2:

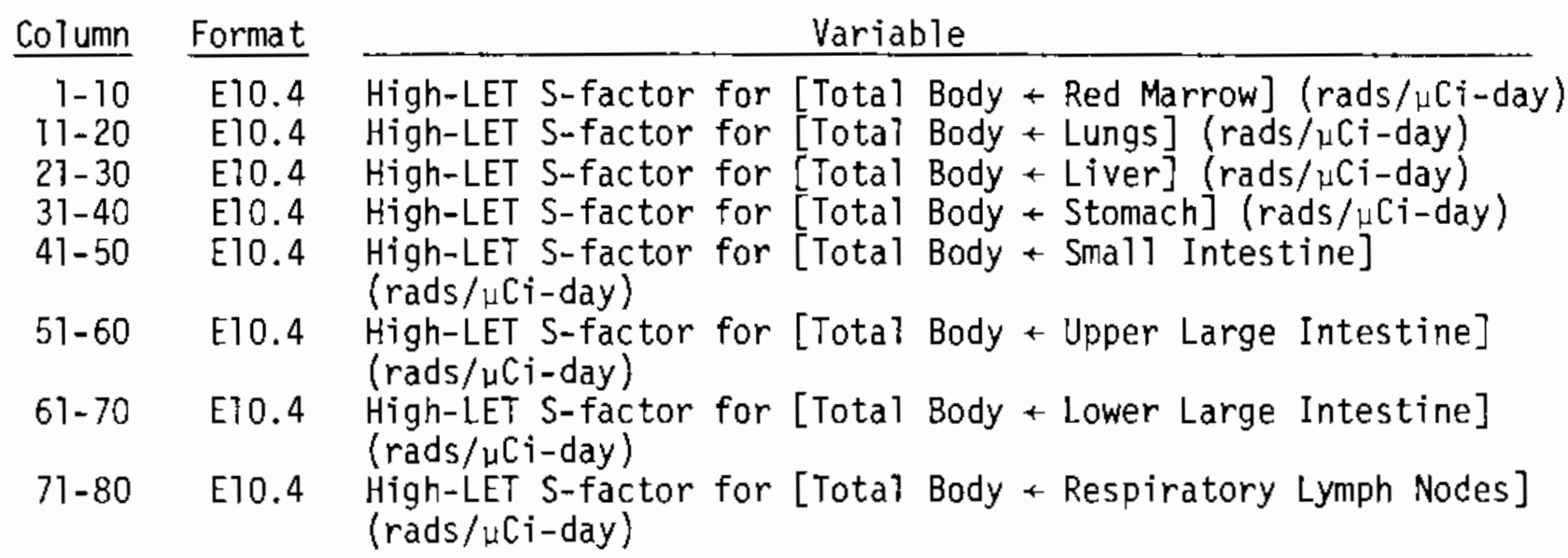

Line 3:

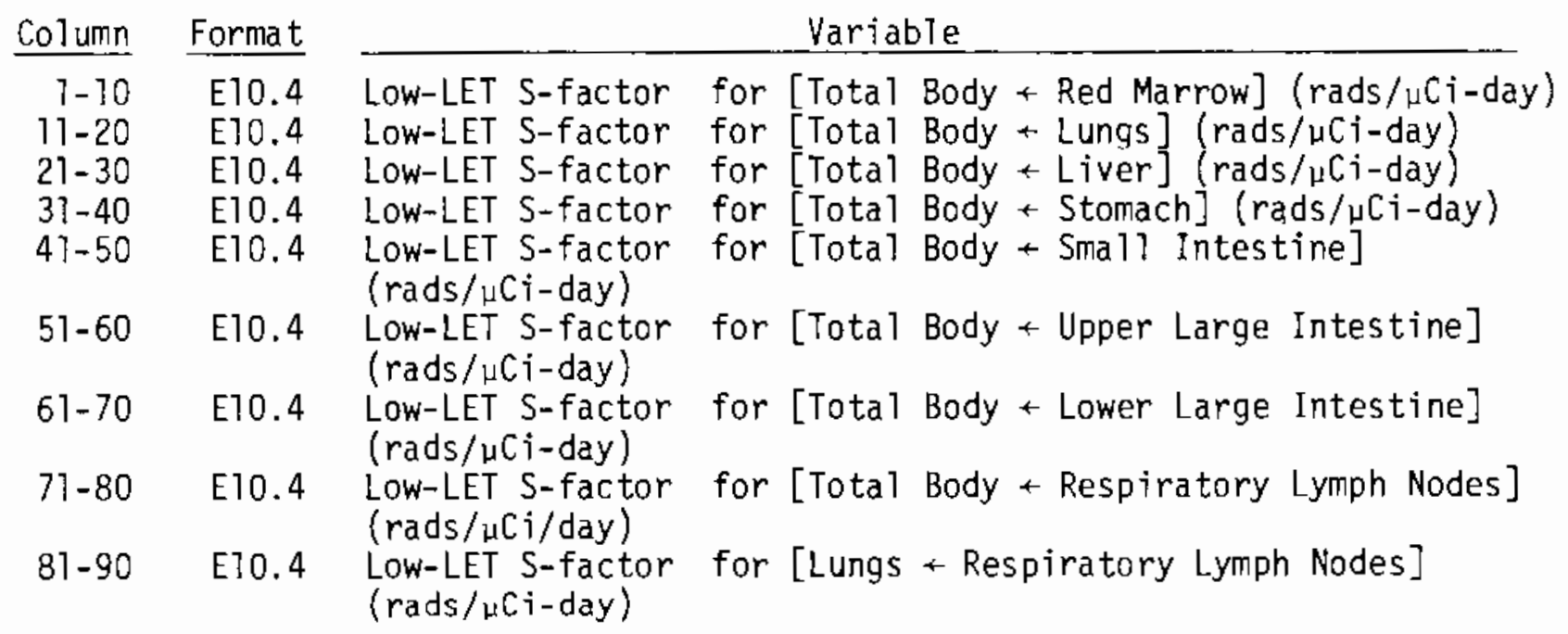

Following the last nuciide's data is a line containing a negative number in columns 9-18.

The second section contains a title in the first line. Following the title there is one line for each iodine isotope and iodine daughter:

\begin{tabular}{|c|c|c|}
\hline Column & Format & Variable \\
\hline $\begin{array}{l}1-2 \\
3-8 \\
9-18 \\
19-28 \\
29-38\end{array}$ & $\begin{array}{l}\text { A2 } \\
\text { A6 } \\
\text { E10.4 } \\
\text { E10.4 } \\
\text { E10.4 }\end{array}$ & $\begin{array}{l}\text { Element abbreviation } \\
\text { Atomic mass number and "M" for isomeric state } \\
\text { LOw-LET S-factor for [Total Body \& Thyroid] (rads } / \mu C i-d a y) \text { ) } \\
\text { Low-LET S-factor for [Red Marrow \& Thyroid] (rads } / \mu C i-d a y) \\
\text { Low-LET S-factor for [Lungs + Thyroid] (rads } / \mu C i-d a y)\end{array}$ \\
\hline
\end{tabular}


The last line in the second section contains a negative number in columns 9-18.

The third section contains a title in the first line. Following the title there is one line for each noble gas nuclide:

Column Format Variable

\begin{tabular}{|c|c|c|}
\hline $\begin{array}{l}1-2 \\
3-8\end{array}$ & $\begin{array}{l}\text { A2 } \\
\text { A6 } \\
\text { E10.4 }\end{array}$ & $\begin{array}{l}\text { Element abbreviation } \\
\text { Atomic mass number and " } M \text { " for isomeric state } \\
\text { High-LET inhalation dose factor for total body } \\
\text { (rad } m^{3} / \mathrm{Cj} \text { sec) }\end{array}$ \\
\hline & E10.4 & $\begin{array}{l}\text { High-LET inhalation dose factor for red marrow } \\
\left.\text { (rad } \mathrm{m}^{3} / \mathrm{Ci} \mathrm{sec}\right)\end{array}$ \\
\hline 7 & $\begin{array}{l}\text { E10.4 } \\
\text { E10.4 } \\
\text { E10.4 } \\
\text { E10.4 }\end{array}$ & $\begin{array}{l}\text { High-LET inhalation dose factor for lungs (rad) } \\
\text { Low-LET inhalation dose factor for total body (rad) } \\
\text { Low-LET inhalation dose factor for red marrow (rad) } \\
\text { Low-LET inhalation dose factor for lungs (rad) }\end{array}$ \\
\hline
\end{tabular}

Following the third section is a line containing a negative number in columns 9-18.

Status of Nuclides in Data Libraries

Table 5 lists the current status of the data libraries used in WRAITH. For each nuclide, the table lists the reference source for the data in each library. The nuclides are identified by the notation which appears in the data libraries, and this notation should be used in WRAITH runs. The entry " $N$ " under organ data source indicates that the nuclide is a noble gas, with two-hour clearance half lives used for any organ in which it is proauced by a parent. Nuclides are grouped by decay chains. Generally, calculations can give complete results only when all data is available for the nuclide and a11 its daughters (daughters are those nuclides listed below the parent in a group). "N/A" indicates that the necessary data is not listed in any of the references used in this table.

A complete listing of the three data libaries used by WRAITH is in Appendix $C$. 
TABLE 5. Status of WRAITH Data Libraries

Reference for Nuclide and Reference for Reference for Ganma Data

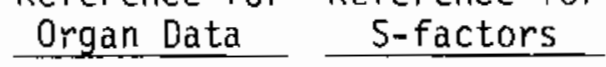

21
21
21
21
21
22
22
22
21

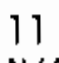

N/A

BET10 20

C $14 \quad 20$

N $13 \quad 20$

F $18 \quad 20$

NA22 20

NA24 20

P $32 \quad 20$

P $33 \quad 23$

AR39 23

AR4 $1 \quad 20$

CA4 120

SC46 20

$p$

CR51 20

MN54 20

MN56 20

FE55 20

FE59 20

C057 20

C058 20

C060 20

NI59 20

NI63 20

NI65 20

CU64 20

ZN65 20

AS76 23

SE79 20

BR82 20

BR84 20

KR90 20

KR9T 23

RB86 20

$N / A$

$N / A$

11
Reference for

Nuclide and Reference for Reference for

Gamma Data

Organ Data $\quad$ S-factors

M093 20

TCI01 20

P0107 20

AG111 20

CDII3M 20

SN177M 23

SN119M 23

SNT27M 23

SN123 23

SBI24 20

TE123M 23

I $130 \quad 20$

CS136 20

PM149 20

SM153 20

EU152 20

EU154 20

EU155 20

EU156 20

GD153 23

TB 160

H0166M

W 181

W 185

U 234

U 236

PU236

PU237

CM246

CM248

CF252

$\begin{array}{ll}22 & \text { N/A } \\ 22 & \text { N/A } \\ 21 & \text { N/A } \\ 21 & 11 \\ 21 & \text { N/A } \\ 21 & \text { N/A } \\ 21 & \text { N/A } \\ 21 & \text { N/A } \\ 21 & \text { N/A } \\ 22 & 11 \\ 22 & \text { N/A } \\ 22 & 11 \\ 22 & 11 \\ 22 & 11 \\ 22 & 11 \\ 21 & \text { N/A } \\ 21 & 11 \\ 21 & 11 \\ 21 & \text { N/A } \\ 21 & 11 \\ 21 & 11 \\ 21 & \text { N/A } \\ 21 & \text { N/A } \\ 21 & \text { N/A } \\ 21 & 12 \\ 21 & 12 \\ 21 & \text { N/A } \\ 21 & \text { N/A } \\ 21 & \text { N/A } \\ 21 & 12 \\ 21 & 12\end{array}$


TABLE 5. (Contd.)

\begin{tabular}{|c|c|c|c|c|c|c|c|}
\hline & $\begin{array}{l}\text { Reference for } \\
\text { Nuclide and } \\
\text { Gamma Data }\end{array}$ & $\begin{array}{l}\text { Reference for } \\
\text { Organ Data }\end{array}$ & $\begin{array}{l}\text { Reference for } \\
\text { S-factors }\end{array}$ & & $\begin{array}{l}\text { Reference for } \\
\text { Nuclide and } \\
\text { Gamma Data }\end{array}$ & $\begin{array}{l}\text { Reference for } \\
\text { Organ Data }\end{array}$ & $\begin{array}{c}\text { Reference for } \\
\text { S-factors }\end{array}$ \\
\hline $\begin{array}{l}\text { ZN69M } \\
\text { ZN69 }\end{array}$ & $\begin{array}{l}20 \\
20\end{array}$ & $\begin{array}{l}22 \\
22\end{array}$ & $\begin{array}{l}11 \\
71\end{array}$ & $\begin{array}{l}\text { Y } 93 \\
\text { ZR93 } \\
\text { NB93M }\end{array}$ & $\begin{array}{l}20 \\
20 \\
20\end{array}$ & $\begin{array}{l}22 \\
22 \\
22\end{array}$ & $\begin{array}{l}11 \\
11 \\
11\end{array}$ \\
\hline BR83 & 20 & 21 & $N / A$ & & & & \\
\hline KR83M & 20 & $N$ & $N / A$ & $\begin{array}{l}\text { ZR95 } \\
\text { NB95M }\end{array}$ & $\begin{array}{l}20 \\
20\end{array}$ & $\begin{array}{l}22 \\
22\end{array}$ & $\begin{array}{l}11 \\
11\end{array}$ \\
\hline $\begin{array}{l}\text { BR85 } \\
\text { KR85M }\end{array}$ & $\begin{array}{l}20 \\
20\end{array}$ & $\begin{array}{l}21 \\
N\end{array}$ & $\begin{array}{l}N / A \\
N / A\end{array}$ & NB95 & 20 & 22 & 11 \\
\hline KR85 & 20 & $\mathrm{~N}$ & $\mathrm{~N} / \mathrm{A}$ & $\begin{array}{l}\text { ZR97 } \\
\text { NB97M }\end{array}$ & $\begin{array}{l}20 \\
20\end{array}$ & $\begin{array}{l}22 \\
22\end{array}$ & $\begin{array}{l}11 \\
11\end{array}$ \\
\hline $\begin{array}{l}\text { KR87 } \\
\text { RB87 }\end{array}$ & $\begin{array}{l}20 \\
20\end{array}$ & $\begin{array}{l}N \\
22\end{array}$ & $\begin{array}{l}N / A \\
11\end{array}$ & NB97 & 20 & 22 & 11 \\
\hline $\begin{array}{l}\text { KR88 } \\
\text { RB88 }\end{array}$ & $\begin{array}{l}20 \\
20\end{array}$ & $\begin{array}{l}N \\
22\end{array}$ & $\begin{array}{l}N / A \\
N / A\end{array}$ & $\begin{array}{l}\text { M099 } \\
\text { TC99M } \\
\text { TC99 }\end{array}$ & $\begin{array}{l}20 \\
20 \\
20\end{array}$ & $\begin{array}{l}22 \\
22 \\
22\end{array}$ & $\begin{array}{l}22 \\
11 \\
11\end{array}$ \\
\hline $\begin{array}{l}\text { KR89 } \\
\text { RB89 } \\
\text { SR89 }\end{array}$ & $\begin{array}{l}20 \\
20 \\
20\end{array}$ & $\begin{array}{l}N \\
22 \\
22\end{array}$ & $\begin{array}{l}N / A \\
N / A \\
11\end{array}$ & $\begin{array}{l}\text { RU103 } \\
\text { RH103M }\end{array}$ & $\begin{array}{l}20 \\
20\end{array}$ & $\begin{array}{l}22 \\
22\end{array}$ & $\begin{array}{l}11 \\
11\end{array}$ \\
\hline Y 89M & 23 & 22 & $N / A$ & $\begin{array}{l}\text { RU105 } \\
\text { RU105M }\end{array}$ & $\begin{array}{l}20 \\
20\end{array}$ & $\begin{array}{l}22 \\
22\end{array}$ & $\begin{array}{l}11 \\
11\end{array}$ \\
\hline $\begin{array}{l}\text { SR90 } \\
\text { Y } 90\end{array}$ & $\begin{array}{l}20 \\
20\end{array}$ & $\begin{array}{l}22 \\
22\end{array}$ & $\begin{array}{l}12 \\
12\end{array}$ & $\mathrm{RH} 105$ & 20 & 22 & 11 \\
\hline Y $90 \mathrm{M}$ & 20 & 22 & 11 & $\begin{array}{l}\text { RUT06 } \\
\text { RHT06 }\end{array}$ & $\begin{array}{l}20 \\
20\end{array}$ & $\begin{array}{l}22 \\
22\end{array}$ & $\begin{array}{l}11 \\
11\end{array}$ \\
\hline $\begin{array}{l}\text { SR91 } \\
\text { Y } 91 M \\
\text { Y } 91\end{array}$ & $\begin{array}{l}20 \\
20 \\
20\end{array}$ & $\begin{array}{l}22 \\
22 \\
22\end{array}$ & $\begin{array}{l}11 \\
11 \\
11\end{array}$ & $\begin{array}{l}\text { PD109M } \\
\text { PD109 } \\
\text { AG109M }\end{array}$ & $\begin{array}{l}23 \\
20 \\
20\end{array}$ & $\begin{array}{l}21 \\
21 \\
21\end{array}$ & $\begin{array}{l}N / A \\
11 \\
11\end{array}$ \\
\hline $\begin{array}{l}\text { SR92 } \\
\text { Y } 92\end{array}$ & $\begin{array}{l}20 \\
20\end{array}$ & $\begin{array}{l}22 \\
22\end{array}$ & $\begin{array}{l}11 \\
11\end{array}$ & $\begin{array}{l}A G 110 M \\
A G 110\end{array}$ & $\begin{array}{l}20 \\
20\end{array}$ & $\begin{array}{l}21 \\
21\end{array}$ & $\begin{array}{l}N / A \\
N / A\end{array}$ \\
\hline
\end{tabular}


TABLE 5. (Contd.)

\begin{tabular}{|c|c|c|c|c|c|c|c|}
\hline & $\begin{array}{l}\text { Reference for } \\
\text { NucTide and } \\
\text { Gamma_Data }\end{array}$ & $\begin{array}{l}\text { Reference for } \\
\text { Organ Data }\end{array}$ & $\begin{array}{l}\text { Reference for } \\
\text { S-factors }\end{array}$ & & $\begin{array}{l}\text { Reference for } \\
\text { Nuclide and } \\
\text { Gamma Data }\end{array}$ & $\begin{array}{l}\text { Reference for } \\
\text { Organ Date }\end{array}$ & $\begin{array}{l}\text { Reference for } \\
\text { S-factors }\end{array}$ \\
\hline $\begin{array}{l}\text { IN174M } \\
\text { IN1 } 14\end{array}$ & $\begin{array}{l}23 \\
23\end{array}$ & $\begin{array}{l}21 \\
21\end{array}$ & $\begin{array}{l}11 \\
17\end{array}$ & $\begin{array}{l}\text { TE133M } \\
\text { TE133 } \\
\text { I } 133\end{array}$ & $\begin{array}{l}20 \\
20 \\
20\end{array}$ & $\begin{array}{l}22 \\
22 \\
22\end{array}$ & $\begin{array}{l}\text { N/A } \\
\text { N/A } \\
11 \& 22\end{array}$ \\
\hline $\begin{array}{l}\text { CDI 15M } \\
\text { CD115 } \\
\text { IN115M }\end{array}$ & $\begin{array}{l}20 \\
20 \\
20\end{array}$ & $\begin{array}{l}21 \\
21 \\
21\end{array}$ & $\begin{array}{l}11 \\
11 \\
11\end{array}$ & $\begin{array}{l}\text { XEI33M } \\
\text { XET } 33\end{array}$ & $\begin{array}{l}20 \\
20\end{array}$ & $\begin{array}{l}\mathrm{N} \\
\mathrm{N}\end{array}$ & $\begin{array}{l}22 \\
22\end{array}$ \\
\hline $\begin{array}{l}\text { IN1 } 15 \\
\text { lat }\end{array}$ & 20 & 21 & 11 & $\begin{array}{l}\text { TE1 } 34 \\
\text { I } 134\end{array}$ & $\begin{array}{l}20 \\
20\end{array}$ & $\begin{array}{l}22 \\
22\end{array}$ & $\begin{array}{l}\text { N/A } \\
11 \& 22\end{array}$ \\
\hline $\begin{array}{l}\text { SN125 } \\
\text { SB125 } \\
\text { TE125M }\end{array}$ & $\begin{array}{l}20 \\
20 \\
20\end{array}$ & $\begin{array}{l}21 \\
22 \\
22\end{array}$ & $\begin{array}{l}N / A \\
N / A \\
11\end{array}$ & $\begin{array}{l}\text { CS134M } \\
\text { CS134 }\end{array}$ & $\begin{array}{l}20 \\
20\end{array}$ & $\begin{array}{l}22 \\
22\end{array}$ & $\begin{array}{l}\text { N/A } \\
11 \& 22\end{array}$ \\
\hline $\begin{array}{l}\text { SN126 } \\
\text { SB126M } \\
\text { SB126 }\end{array}$ & $\begin{array}{l}20 \\
20 \\
20\end{array}$ & $\begin{array}{l}21 \\
22 \\
22\end{array}$ & $\begin{array}{l}N / A \\
N / A \\
N / A\end{array}$ & $\begin{array}{l}\text { I } 135 \\
\text { XE135M } \\
\text { XEI35 } \\
\text { CST } 35\end{array}$ & $\begin{array}{l}20 \\
20 \\
20 \\
20\end{array}$ & $\begin{array}{l}22 \\
N \\
N \\
22\end{array}$ & $\begin{array}{l}11 \& 22 \\
22 \\
22 \\
11 \& 22\end{array}$ \\
\hline $\begin{array}{l}\text { SB127 } \\
\text { TE127M } \\
\text { TE127 }\end{array}$ & $\begin{array}{l}20 \\
20 \\
20\end{array}$ & $\begin{array}{l}22 \\
22 \\
22\end{array}$ & $\begin{array}{l}22 \\
17 \\
11\end{array}$ & $\begin{array}{l}\text { XEI } 37 \\
\text { CSI37 } \\
\text { BA137M }\end{array}$ & $\begin{array}{l}20 \\
20 \\
20\end{array}$ & $\begin{array}{l}\mathrm{N} \\
22 \\
22\end{array}$ & $\begin{array}{l}\text { N/A } \\
11 \\
11\end{array}$ \\
\hline $\begin{array}{l}\text { TEI29M } \\
\text { TEI29 } \\
\text { I } 129\end{array}$ & $\begin{array}{l}20 \\
20 \\
20\end{array}$ & $\begin{array}{l}22 \\
22 \\
22\end{array}$ & $\begin{array}{l}11 \\
11 \\
11 \& 22\end{array}$ & $\begin{array}{l}\text { XEI } 38 \\
\text { CSI38 }\end{array}$ & $\begin{array}{l}20 \\
20\end{array}$ & $\begin{array}{l}\mathrm{N} \\
22\end{array}$ & $\begin{array}{l}N / A \\
N / A\end{array}$ \\
\hline $\begin{array}{l}\text { TEI37M } \\
\text { TEI31 } \\
\text { I } 131 \\
\text { XEI3TM }\end{array}$ & $\begin{array}{l}20 \\
20 \\
20 \\
20\end{array}$ & $\begin{array}{l}22 \\
22 \\
22 \\
N\end{array}$ & $\begin{array}{l}11 \\
11 \\
11822 \\
\text { N/A }\end{array}$ & $\begin{array}{l}\text { XE139 } \\
\text { CSI39 } \\
\text { BAI39 }\end{array}$ & $\begin{array}{l}23 \\
20 \\
20\end{array}$ & $\begin{array}{l}N \\
22 \\
22\end{array}$ & $\begin{array}{l}N / A \\
N / A \\
N / A\end{array}$ \\
\hline $\begin{array}{l}\text { TEI } 32 \\
\text { I } 132\end{array}$ & $\begin{array}{l}20 \\
20\end{array}$ & $\begin{array}{l}22 \\
22\end{array}$ & $\begin{array}{l}11 \\
11822\end{array}$ & $\begin{array}{l}\text { XE140 } \\
\text { CS140 } \\
\text { BA140 } \\
\text { LA140 }\end{array}$ & $\begin{array}{l}23 \\
23 \\
20 \\
20\end{array}$ & $\begin{array}{l}\mathrm{N} \\
22 \\
22 \\
22\end{array}$ & $\begin{array}{l}\text { N/A } \\
\text { N/A } \\
17 \\
11\end{array}$ \\
\hline
\end{tabular}


IABLE 5. (Contd.)

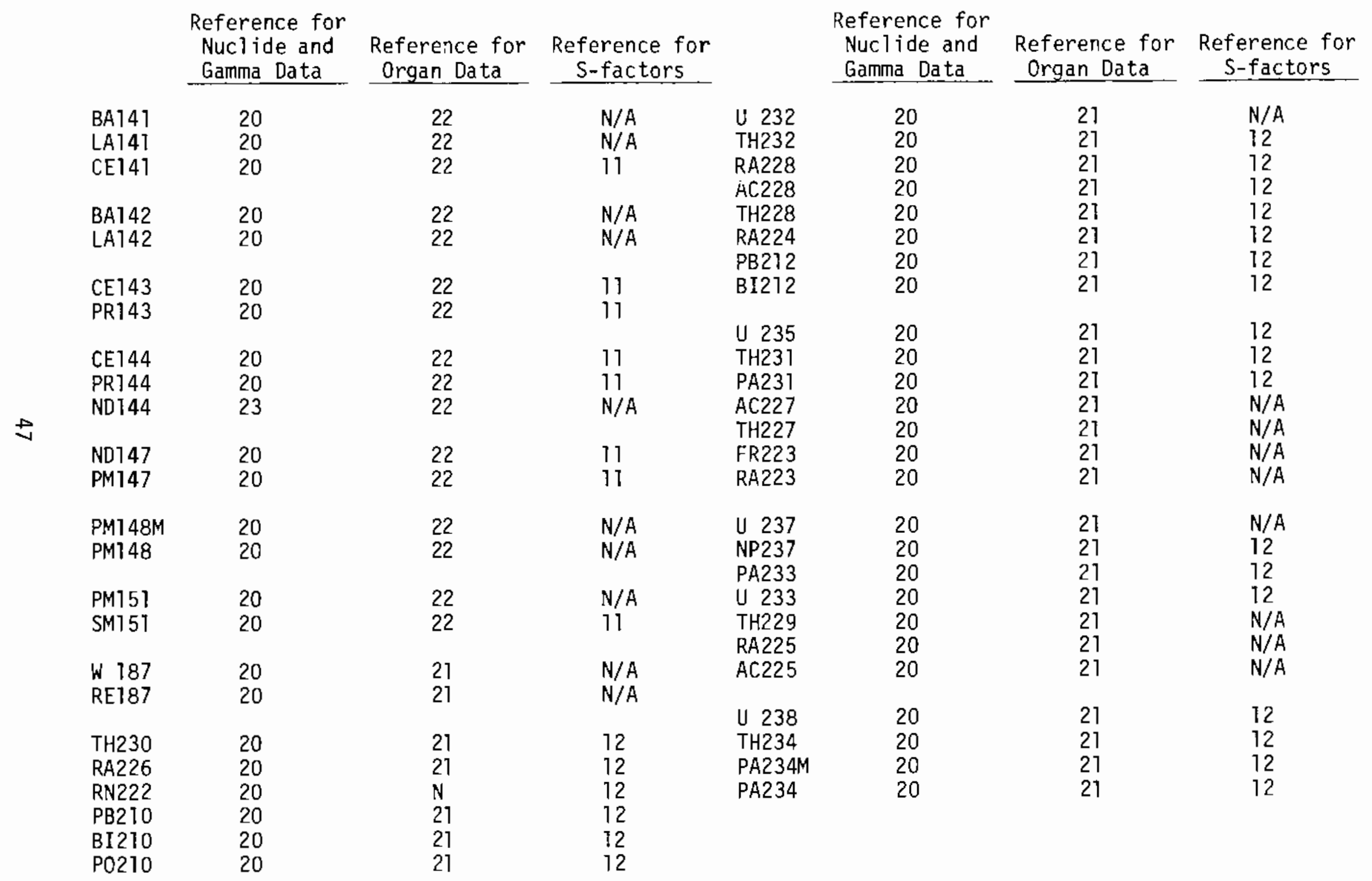


TABLE 5. (Contd.)

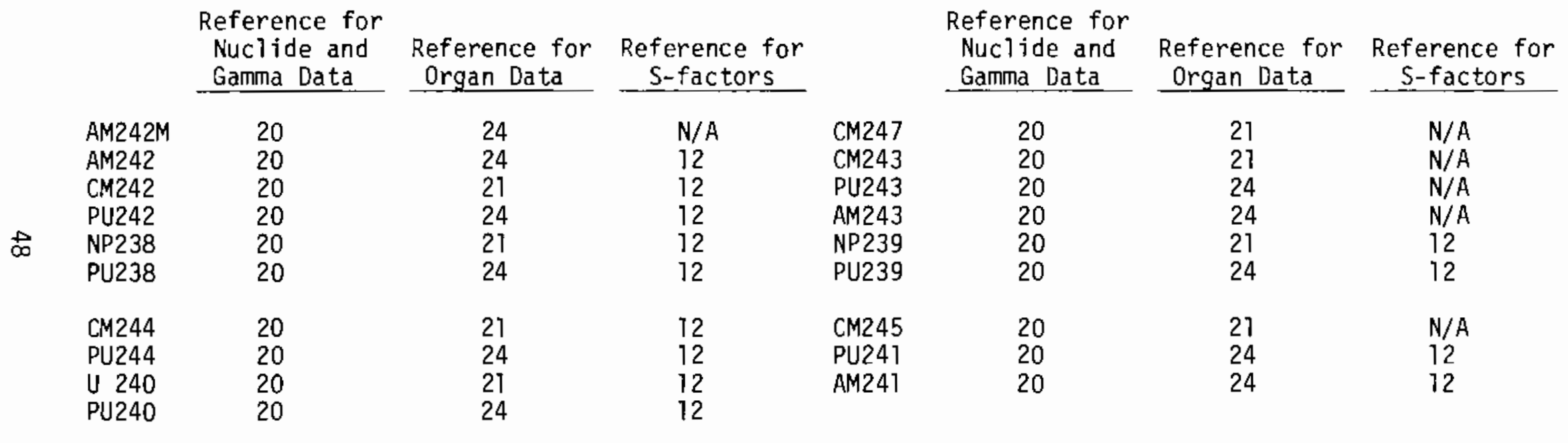




\section{PROGRAM EXECUTION}

WRAITH was written to be run from an interactive terminal on the UNIVAC $1100 / 44$. The user assigns data and program files and begins execution from a remote terminal. After program execution is initiated, the user types in responses to prompting messages printed by the program. This input from the terminal directs the program to choose the appropriate options, and it provides the job-specific data needed in the calculations. At the end of program execution, a summary of the calculated doses is printed at the teminal, and the detailed output can be routed to a high-speed line printer.

Appendix 0 contains a detailed description of the user input. This appendix is intended to be sufficiently detailed to be a self-contained unit. Appendix 0 also contains a description of the required control cards and a description of the output. 


\section{REFERENCES}

T. Gifford, Jr., F. A. 1968. "An Outline of Theories of Diffusion in the Lower Layers of the Atmosphere." In Meteorology and Atomic Energy, ed. D. H. Slade, TID-24190, National Technical Information Service, Springfield, VA 2216T.

2. U.S. Nuclear Regulatory Commission. 1979. Atmospheric Dispersion Models for Potential Accident Consequence Assessments at Nuclear Power PTants. Regulatory Guide 1.745, U.S. NucTear Regulatory Commission, Washington, DC 20555.

3. Briggs, G. A., I. VanderHoven, R. J. Engleman, and J. Halitsky. 1968. "Processes 0ther than Natural Turbulence Affecting Effluent Concentrations." In Meteorology and Atomic Energy. ed. D. H. Slade, TID-24190, National Technical Information Service, Springfield, VA $2216 \mathrm{~T}$.

4. Rupp, A. F., S. E. Bea11, L. P. Bornwasser, and D. H. Johnson. 1948. Dilution of Stack Gases in Cross Winds. U.S.A.E.C. Report AECD-1811.

5. Briggs, G. A. 1969. Plume Rise. TID-25075, National Technical Information Service, Springfield, VA 22161.

6. U.S. Nuclear Regulatory Commissira. 1977. Methods for Estimating Transport and Dispersion of Gaseous Effluents in Routine Releases from LightWater-Cooled Reactors. Regulatory Guide 1.171, U.S. Nuclear Regulatory Commission, Washington, DC 2.555.

7. Sagendorf, J. F. and J. T. Go11. 1977. X0QD0Q-Program for the Meteorological Evaluation of Routine Effluent Releases at Nuclear Power Plants. NUREG-0324, U.S. NucTear Regulatory Commission, Washington, DC 20555.

8. Bateman, H. 1910. "The Solution of a System of Differentiat Equations 0ccurring in the Theory of Radioactive Transformations." Proc. Cambridge Phi1. Soc. 15:423.

9. Berger, M. J. 1968. Engineering Compendium on Radiation Shielding. Vol. I. Springer-Verlag, New York, New York.

10. Strenge, D. L., E. C. Watson, and J. R. Houston. 1975. SUBDOSA A Computer Program for Calculating External Doses from Accidenta? Atmospheric Releases of Radionuclides. BNWL-B-351/UC-11, Pacific Northwest Laboratory, Richland, WA 99352.

11. Snyder, W. S., M. R. Ford, G. G. Warner, and S. B. Watson. 1974 and 1975. A Tabulation of Dose Equivalent per Microcurie-Day for Source and Target Organs of an Adult for Various Radionuclides. ORNL-5000, Parts 1 and 2 . National Technical Information Serivce, Springfield, VA 22161. 
12. Dunning, Jr., D. E., J. C. Pleasant, and G. G. Killough. 1977. SFACTR: A Computer Code for Calculating Dose Equivalent to a Target Organ per Microcurie-Day Residence of a Radionucl ide in a Source Organ. ORNL/ NUREG/TM-85, National Technical Information Service, Springfield, VA $2216 \mathrm{~T}$.

13. Morrow, P. E., D. V. Bates, B. R. Fish, T. F. Hatch, and T. T. Mercer. 1966. "Deposition and Retention Models for Internal Dosimetry of the Human Respiratory Tract." Health Phys. 12:173-207.

14. U.S. Nuclear Regulatory Commission. 1975. Reactor Safety Study: An Assessment of Accident Risks in U.S. Commercial Nuclear Power Plants, Appendix VI, Calculation of Reactor Accident Consequences. WASH-1400 (NUREG-75/104), U.S. Nuclear Regulatory Commission, Washington, DC $2 D 555$.

15. Killough, G. G., D. E. Dunning, Jr., and J. C. Pleasant. 1978. INREM-II: A Computer Implementation of Recent Models for Estimating the Dose Equivalent to Organs of Man from an Inhaled or Ingested Radionuclide. ORNL/NUREG/TM-84, National Technical Information Service, Springfield, VA 22161.

16. International Commission on Radiological Protection (ICRP). 1972. The Metabol ism of Compounds of Plutonium and Other Actinides. ICRP Publication 19, Pergammon Press, New York, New York.

17. Hamawi, J. N. 1971. "A Useful Recurrence Formula for the Equations of Radioactive Decay." Nuclear Technology 11:84-88.

18. Scherpe1z, R. I. and A. E. Desrosiers. 3981. "A Modification to a Recurrence Formula for Linear First Order Equations," Submitted to Health Physics. Intended date of publication January 1981.

19. Eve, I. S. 1966. "A Review of the Physiology of the Gastrointestina1 Tract in Relation to Radiation Doses from Radioactive Materials." Hea 1 th Phys. 12:131-161.

20. Kocher, D. C. 1977. Nuclear Decay Data for Radionuclides Occurring in Routine Releases from Nuclear Fuel Cycle Facilities. ORNL/NUREG/TM-102, National Technical Infonmation Service, Springfield, VA 22161.

21. International Commission on Radiological Protection (ICRP). 1959. Report on Committee II of Permissible Dose for Internal Radiation. ICRP Pub7ication 2, Pergamon Press, Mew York.

22. Killough, G. G., D. E. Dunning, Jr., S. R. Bernard, and J. C. Pleasant. 1978. Estimates of Internal Dose Equivalent to 22 Target Organs for Radionuclides Occurring in Routine Releases from Nuclear Fuel-Cycle Facilities, Vol. I. NUREG/CR-0150, ORNL/NUREG/TM-190, National Technical Information Service, Springfield, VA 22161. 
23. Lederer, C. M. and V. S. Shirley, eds. 1978. Table of Isotopes. 7 th Ed. John Wiley and Sons, New York, New York.

24. International Commission on Radiological Protection (ICRP). 1979. Limits for Intakes of Radionuclides by Workers. ICRP Publication 30, Pergamon Press, New York. 
APPENOIX A

LISTING OF COOE SOIJRCE OECK 


\section{APPENDIX A \\ LISTING OF CODE SDURCE DECK}

NOTE: Text appears in microfiche form at end of report. 



\section{APPENDIX B}

\section{DICTIONARY OF VARIABLES IN COMMON}


APPENDIX B

\section{DICTIONARY OF VARIABLES IN COMMON}

\begin{tabular}{|c|c|c|}
\hline $\begin{array}{r}\operatorname{ALAMB}(200,3,6) \\
(N U C, I 0, I C)\end{array}$ & $=$ & $\begin{array}{l}\text { Biological decay constant for nuclide NUC for the } \\
\text { ICth term of the retention function of organ } 10\end{array}$ \\
\hline $\begin{array}{r}\operatorname{ALAMDA}(200) \\
(\text { NUC })\end{array}$ & $=$ & Radiological decay constant for nuclide NUC \\
\hline $\begin{array}{r}\operatorname{ALBTHY}(4,6) \\
(I E, I C)\end{array}$ & $=$ & $\begin{array}{l}\text { Biological decay constant for the ICth term of the } \\
\text { retention function in the thyroid for element IE }\end{array}$ \\
\hline $\begin{array}{r}\text { ALRTHY }(13) \\
(\text { LTHY) }\end{array}$ & $=$ & $\begin{array}{l}\text { Radiological decay constant for the LTHYth nuclide } \\
\text { used in the thyroid calculations }\end{array}$ \\
\hline $\begin{array}{l}\text { AW }(200) \\
\text { (NUC) }\end{array}$ & $=$ & $\begin{array}{l}\text { Atomic mass number ( } p \text { lus isomeric state, if any) of } \\
\text { nuclide NUC }\end{array}$ \\
\hline BDAREA & $=$ & $\begin{array}{l}\text { Cross-sectional area of building for a ground-level } \\
\text { release }\end{array}$ \\
\hline BRATE & $=$ & Ventilation rate \\
\hline $\begin{array}{r}\operatorname{BURDN}(9,200) \\
(10, N U C)\end{array}$ & $=$ & Activity-residence time of nuctide NUC in organ I0 \\
\hline $\begin{array}{r}\operatorname{COELM}(200,3,6) \\
(N U C, I 0, I C)\end{array}$ & $=$ & $\begin{array}{l}\text { Coefficient for term IC of the retention function } \\
\text { of nuclide NUC in organ IO }\end{array}$ \\
\hline $\operatorname{COETHY}(4,6)$ & $=$ & $\begin{array}{l}\text { Coefficient for term IC of the retention function } \\
\text { of element IE in the thyroid }\end{array}$ \\
\hline 03 & $=$ & $\begin{array}{l}\text { Fraction of particles deposited in } \mathrm{N}-\mathrm{P} \text { region of } \\
\text { respiratory tract }\end{array}$ \\
\hline D4 & $=$ & $\begin{array}{l}\text { Fraction of particles deposited in } T-B \text { region of } \\
\text { respiratory tract }\end{array}$ \\
\hline D5 & $=$ & $\begin{array}{l}\text { Fraction of particles deposited in } \mathrm{p} \text { region of } \\
\text { respiratory tract }\end{array}$ \\
\hline DAT & $=$ & Date of WRAITH run \\
\hline $\begin{array}{c}D C(3) \\
\text { (I0) }\end{array}$ & $=$ & Summed low-LET dose commitment to organ 10 \\
\hline
\end{tabular}




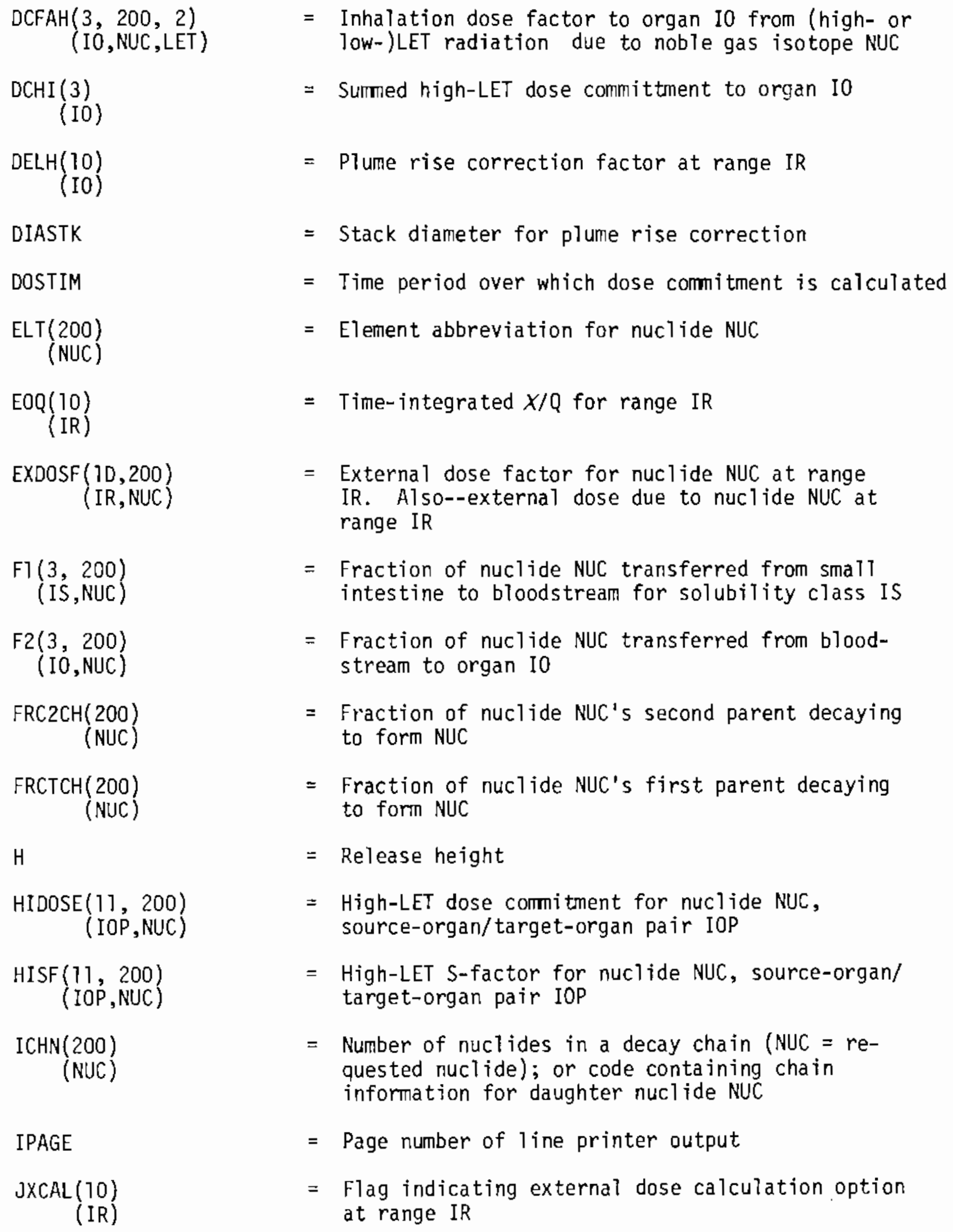




\begin{tabular}{|c|c|c|}
\hline $\begin{array}{r}\mathrm{LB}(200,3) \\
\quad(\mathrm{NUC}, \mathrm{I0})\end{array}$ & $=$ & $\begin{array}{l}\text { Number of terms in retention function for nuclide } \\
\text { NUC in organ } 10\end{array}$ \\
\hline $\begin{array}{l}\operatorname{LBTHY}(4) \\
(\mathrm{IE})\end{array}$ & $=$ & $\begin{array}{l}\text { Number of terms in retention function for element } \\
\text { IE in thyroid }\end{array}$ \\
\hline $\begin{aligned} \operatorname{LTHY}(200) \\
(\mathrm{NUC})\end{aligned}$ & $=$ & $\begin{array}{l}\text { Code to identify nuclide NUC as an iodine isotope } \\
\text { or daughter }\end{array}$ \\
\hline $\begin{array}{l}\text { LTP1(13) } \\
\quad(\text { LTHY) }\end{array}$ & $=$ & $\begin{array}{l}\text { Code to identify first parent of iodine isotope or } \\
\text { daughter LTHY }\end{array}$ \\
\hline $\operatorname{LTP2}(13)$ & $=$ & $\begin{array}{l}\text { Code to identify second parent of iodine isotope } \\
\text { or daughter LTHY }\end{array}$ \\
\hline $\begin{array}{r}\text { NUCOUP }(200) \\
(\text { NUC })\end{array}$ & $=$ & $\begin{array}{l}\text { Code to identify any nuclide, NUC, which is both } \\
\text { a requested nuclide and the daughter of another } \\
\text { requested nuclide }\end{array}$ \\
\hline $\begin{array}{r}Q(200) \\
(N \cup C)\end{array}$ & $=$ & Quantity of nuclide, NUC, in the air at any range \\
\hline QHSTK & $=$ & Heat rate of gases leaving the stack \\
\hline $\mathrm{R}(10)$ & $=$ & $\begin{array}{l}\text { Range IR (or the release point to dose point } \\
\text { distance) }\end{array}$ \\
\hline $\begin{array}{r}\operatorname{SFACT}(9,3,200) \\
(I S, I T, N U C)\end{array}$ & $=$ & $\begin{array}{l}\text { Low-LET S-factor for nuclide NUC residing in source } \\
\text { organ IS, irradiating target organ IT }\end{array}$ \\
\hline $\begin{array}{l}\operatorname{SFTHY}(3,13) \\
\quad(I T, L T H Y)\end{array}$ & $=$ & $\begin{array}{l}\text { Low-LET S-factor for nuclide LTHY residing in the } \\
\text { thyroid, irradiating target organ IT }\end{array}$ \\
\hline $\operatorname{SOLCLS}(200)$ & $=$ & $\begin{array}{l}\text { Code to identify the percentage of nuclide NUC in } \\
\text { each solubility class }\end{array}$ \\
\hline TAIR & $=$ & Air temperature for plume rise correction \\
\hline $\begin{aligned} \text { THFRT }(13) \\
(\text { LTHY })\end{aligned}$ & $=$ & $\begin{array}{l}\text { Fraction of first parent of iodine daughter LTHY } \\
\text { which decays into LTHY }\end{array}$ \\
\hline $\begin{array}{l}\text { THFR2 (13) } \\
(\text { LTHY) }\end{array}$ & $=$ & $\begin{array}{l}\text { Fraction of second parent of iodine daughter LTHY } \\
\text { which decays into LTHY }\end{array}$ \\
\hline $\begin{array}{l}\text { THYBUR(13) } \\
(\text { LTHY })\end{array}$ & $=$ & $\begin{array}{l}\text { Activity-residence time of nuclide LTHY in the } \\
\text { thyroid }\end{array}$ \\
\hline $\begin{aligned} \operatorname{THYDOS}(3,13) \\
(\mathrm{IT}, \mathrm{LTHY})\end{aligned}$ & $=$ & $\begin{array}{l}\text { Dose from nuclide LTHY residing in the thyroid to } \\
\text { target organ IT }\end{array}$ \\
\hline
\end{tabular}




\begin{tabular}{|c|c|c|}
\hline THYF2 & $=$ & $\begin{array}{l}\text { Fraction of iodine transferred from bloodstream to } \\
\text { thyroid }\end{array}$ \\
\hline TIM & $=$ & Time of day job is run \\
\hline TITLJ & $=$ & Titie of job \\
\hline TMPGRD & $=$ & $\begin{array}{l}\text { Temperature gradient in air for plume rise } \\
\text { correction }\end{array}$ \\
\hline $\operatorname{TOTDOS}\left(\begin{array}{l}10,3,2) \\
(\mathrm{IS}, \mathrm{IT}, \mathrm{LET})\end{array}\right.$ & $=$ & $\begin{array}{l}\text { Summed cross-organ dose for high- or low-LET } \\
\text { radiation from material residing in source organ } \\
\text { IS irradiating target organ IT }\end{array}$ \\
\hline TSTACK & $=$ & Temperature of effluent coming out of the stack \\
\hline UBAR & $=$ & $\begin{array}{l}\text { Average wind speed at height of stack for elevated } \\
\text { release, or at } 10 \text { meter elevation for ground-level } \\
\text { release }\end{array}$ \\
\hline VELSTK & $=$ & Velocity of effiuent coming out of the stack \\
\hline VOLSTK & $=$ & $\begin{array}{l}\text { Volume flow rate of effluent coming out of the } \\
\text { stack }\end{array}$ \\
\hline $\begin{array}{r}\text { XDFLIB }(200) \\
(N U C)\end{array}$ & $=$ & $\begin{array}{l}\text { External dose factor for nuclide NUC from data } \\
\text { library }\end{array}$ \\
\hline $\begin{array}{r}\text { XDOSE }(9,3,200) \\
(I S, I T, N U C)\end{array}$ & $=$ & $\begin{array}{l}\text { Low-LET cross-organ doses for nuclide NUC residing } \\
\text { in source organ IS irradiating target organ IT }\end{array}$ \\
\hline
\end{tabular}


APPENDIX C

LISTING OF DATA LIBRARIES 
APPENDIX C

\section{LISTING OF DATA LIBRARIES}

Line Printer Output for Sample Run 2

NOTE: Text appears in microfiche form at end of report. 

APPENDIX D

WRAITH EXECUTION 
APPENDIX D

\section{WRAITH EXECUTION}

WRAITH is designed to be run on the UNIVAC 1100/44, from an interactive terminal. Input data files are assigned at the terminal, data defining the specific case are entered by the user at the terminal, and a brief summary of the calculated results are printed at the terminal. A detailed output is produced in a file which may be printed automatically at the main line printer, or routed to any other printer.

This appendix is partiy intended for the user who is unfamiliar with WRAITH, and has not carefully read the sections of this document describing the mathematical models and the computer program. Thus it includes many explanations which duplicate discussions in those sections. The user who is more familiar with WRAITH will find Tables 0.1, 0.2, and 0.3, and the section on Instructions for Running WRAITH, most important.

\section{DATA LIBRARIES}

Three libraries contain data needed by WRAITH:

- RSS*NUCDAT (logical unit \#10): This is the Radionuclide Master Data Library, containing the half life and radionuclide chain decay scheme for each nuclide. It also contains similar data for nuciides used in the thyroid calculations.

- RSS*ORGDAT (logical unit 12 ): This is the organ data library. It contains biological data for each nuclide, such as blood-to-organ transfer fractions, and organ retention function coefficients. It also contains the gamma energies and abundances for calculating S-factors and external dose factors.

- RSS*SFACTR (logical unit 14 ): A number of S-factors are stored in SFACTR. Generaliy these include the S-factors which cannot be calculated using gamma energies alone. Thus all high-LET S-factors, 
and those where a given organ is both source and target, are included in the data library. External dose factors (5-cm depth doses) for submersion in an infinite cloud are also stored here, as are inhalation dose factors for noble gases.

\section{INPUT FROM TERMINAL}

Four types of statements are entered by the user from the remote terminal at the start of each run to specifically define the case:

I. A job title to be listed on each page of the output.

II. A namelist, called "\$INPUT", which specifies the optional calculations to be performed, and gives many of the input values.

III. Data specifying the quantity and clearance class of each nuclide in the release.

IV. External dose factors for each nuclide at each range (user-input dose factors are requested only when that option is specified).

After execution of WRAITH is initiated, the code will type out a brief message asking for the appropriate input. The message is followed by a carriage return, and the computer will print a prompting "greater-than" sign $(>)$, indicating that it is ready for a line of input. The user should type the appropriate information directly after the prompt. A detailed description of the user input follows.

I. JOB TITLE

Prompt message: ENTER JOB TITLE (MAX. 80 CHARACTERS)

Format: $A 80$

Since the format is $A 80$, whatever is entered in the first 80 spaces after the computer's prompt sign will be read by WRAITH as the job title. It will be printed on the title page of the line printer output and reproduced at the top of each succeeding page of output. Thus it is an easy way for the user to identify runs. 


\section{NAMELIST}

\section{Prompt message: ENTER NAMELIST}

Variables entered: Table D.1 lists the variables in the Namelist, the type of variable (integer, real, or alphameric), the units, and a brief description of each.

TABLE D.]. Variables in Namelist

\begin{tabular}{|c|c|c|c|}
\hline Variable & Type & Units & Description \\
\hline NR & integer & --- & Number of ranges \\
\hline$R(10)$ & real & meters & Ranges \\
\hline PASCLS & alpha (A1) & ---- & Pasquill stability class \\
\hline UBAR & real & $\pi / \sec$ & Average wind specd \\
\hline$H$ & real & $\pi$ & Stack height \\
\hline $\operatorname{EOQ}(10)$ & real & $s / m^{3}$ & $E / Q$ at each range \\
\hline AMAO & real & microns & $\begin{array}{l}\text { Average median aerodynamic diameter of } \\
\text { particies }\end{array}$ \\
\hline 03 & reat & ---- & $\begin{array}{l}\text { Fraction of inhaled particles deposited in } \\
\mathrm{N}-\mathrm{P} \text { region }\end{array}$ \\
\hline 04 & real & --- & $\begin{array}{l}\text { Fraction of inhaled particles deposited in } \\
\text { T-B region }\end{array}$ \\
\hline 05 & real & --- & $\begin{array}{l}\text { Fraction of inhaled particles deposited in } \\
\text { p region }\end{array}$ \\
\hline YNUCED & integer &.-- & Number of nuclides \\
\hline DOSTIM & real & days & Time period for dose commitant calculation \\
\hline ERATE & reat & $\mathrm{cm}^{3} / \mathrm{sec}$ & Ventilation rate \\
\hline QFALPH & raal & --- & Quality factor for alpha \\
\hline$J X C A L(10)$ & integer & --- & $\begin{array}{l}\text { Flags to indicate type of external dose } \\
\text { calculations }\end{array}$ \\
\hline ILPLET & integer & --- & $\begin{array}{l}\text { Flag to indicate use of plume depletion } \\
\text { factors }\end{array}$ \\
\hline BDAREA & rea? & $\pi^{2}$ & $\begin{array}{l}\text { Bullding area for ground-level or vent } \\
\text { releases }\end{array}$ \\
\hline CE! $H(10)$ & real & $\pi$ & Plime rise correction sactors \\
\hline WELSTK & real & $\mathrm{m} / \mathrm{sec}$ & Helocity of gas leaving stack \\
\hline DIASTK & real 1 & $\pi$ & Diameter of stack \\
\hline QHSTK & real & $\mathrm{cal} / \mathrm{s}$ & Heat enission rate of stack \\
\hline TAIR & real & ${ }^{2} \mathrm{~K}$ & Ambient air temperature at top of stack \\
\hline TSTACK & rea $]$ & ${ }^{\circ} \mathrm{K}$ & Temperature of effluent leaving stack \\
\hline TMPGRD & real & ${ }^{\circ} \mathrm{K} / \pi$ & Temperature gradient of air at too of stack \\
\hline VOLSTK & rea 1 & $\mathrm{~m}^{3} / 5$ & Volume flow rate of effluent leaving stack \\
\hline
\end{tabular}


Format: Free format, with certain important restrictions:

a) The first 8 characters following the prompt must be $\not b$ \$INPUT $\not b$, where " $b$ " indicates a blank space.

b) Variables are given values by assignment statements, such as "UBAR=2.5"; assignment statements must be separated by cormas. Variables may be assigned in any order, and unnecessary variables may be omitted. To terminate the assignment statement, enter \$END (or just \$) after the last assignment statement.

c) Assignment statements should use the correct type of constants: integers should not have decimal points; real numbers should have decimal points, and scientific notation can be used by putting an $E$ before the exponent $\left(1.5 \times 10^{3}: 1.5 \mathrm{E}+3\right)$. PASCLS is a one-character alphameric symbol, which must be in quotes (PASCLS=' $C^{\prime}$ ).

d) Arrays: Each of the four arrays have one element for each range. Values can be assigned by having the array name on the left side of the assignment statement, and values separated by commas on the right $(R=100,200$., 300.). A specific array element can be specified $[R(3)=300$.$] , and an asterisk can be used to assign the$ same value to several elements of an array (DELH=3.3, $4.7,8^{\star} 4.9$ ). Note that unneeded array elements can be omitted.

Sample Name1 ist Entries:

ENTER NAMELIST

$>\$$ \$INPUT \& $N R=2, R=100 ., 1000 ., P A S C L S=B^{\prime}, U B A R=4 ., H=10 ., A M A D=1.0$, NNUCLD $=3$, BRATE $=300 .$, DOSTIM $=300 .$, JXCAL $=1, D E L H=2 \star 2.1, \$ E N D$

or

ENTER NAMELIST

$>\$$ \$INPUT \& BRATE=1., D3 =.310, D4=8. E-2, D5=0.259, DOSTIM=1825D., NNUCLD $=1, \$$ 
A discussion of the Namelist variables must necessarily include a discussion of the optional modes for running WRAITH, and some of the idiosyncracies of the code itself.

For al1 Cases

NNUCLD: The number of nuclides released must be specified (see the discussion of limits to NNUCLD in the nuclide data entry description).

DOSTIM: The number of days in the dose commitment time period must be specified.

D3, D4, and D5: The fractions of inhaled particles deposited in the three regions of the respiratory tract (D3: nasopharyngea? region, D4: tracheobronchial region, D5: pulmonary region) may be input directly. If not, directly input, they must be calculated by inputting:

AMAD: The average median aerodynamic diameter of the particles, used to calculate D3, D4, and D5. The model is only valid for AMAD values between 0.1 and 20 microns.

QFALPH: The quality factor for alphas, may be input or omitted. If omitted, doses will be calculated in rads, with no dose equivalents. If QFALPH is input, its value will be used to calculate dose equivalents (in rems) from the doses (in rads).

Bypass Atmospheric Dispersion Calculation

If the user knows the quantity of radioactive material inhaied, there is no need to perform the atmospheric dispersion calculation, and it can be omitted. The flag for bypassing the atmospheric dispersion calculation is setting the Namelist variable "BRATE" equal to one.

The only other variables entered in Namelist for this mode of calculation are those listed above: NNUCLD; DOSTIM; QFALPH (optiona1); and D3, D4, D5, or AMAD.

When the atmospheric dispersion calculation is bypassed, the externat dose calculation is also omitted. The quantity of material (entered in the nuclide data input) for each nuclide is in units of $\mu \mathrm{Ci}$ inhaled--for all other cases the units are $\mathrm{Ci}$ released. 
Atmospheric Dispersion Calculation

The values for $E / Q\left({ }^{X} / Q\right.$ integrated over time) may be either input directly by the user, or calculated by WRAITH. For both options, the following variables must be included in the Namelist:

NR: The number of ranges for performing dose calculations. $N R \leq 10$.

R: The ranges (distances from release site to receptor sites), in meters. There must be NR values of $R$ input.

UBAR: The average windspeed, in $\mathrm{m} / \mathrm{sec}$. For ground level and vent releases UBAR should be the windspeed 10 meters above the ground. For elevated releases, the windspeed should be that measured at the height of the top of the stack. Although UBAR is primarily used in the calculation of EOQ, it is also used in calculating radioactive decay between the source and receptor sites, and therefore it must have a value even when EOQ values are input by the user.

BRATE: The ventilation rate, in $\mathrm{cm}^{3} / \mathrm{sec}$. BRATE must be greater than $I$ to perform atmospheric dispersion calculations.

JXCAL: is an array of integers to indicate the type of external dose calculation to be performed at each range. Thus, JXCAL (1) determines the external dose calculation technique used at the first range, JXCAL(2) at the second, etc.

JXCAL=1: WRAITH Calculates the external dose factor at the specified range. (Remember: this option cannot be used for user-input E/Q).

JXCAL=0: Dose factors for submersion in a semi-infinite cloud are taken from a library.

JXCAL $=-1$ : The user inputs dose factors calculated in a previous WRAITH run.

Defauit values for JXCAL are all zero. If JXCAL is not specified in the Namelist input, submersion dose factors will be used for all ranges. Likewise, if JXCAL values are specified for only several ranges, the other JXCAL values will all be zero. A discussion of the external dose calculation options is included at the end of the input instructions.

Enter $E / Q$ Values

If the user knows the values for $E / Q$ much of the atmospheric dispersion calculation can be avoided by entering these values in the array EOQ in the 
Namelist. One EOQ value for each range must be entered, with units of $\mathrm{sec} / \mathrm{m}^{3}$. (Sample input: $E O Q=7.30 \mathrm{E}-5,1.97 \mathrm{E}-5,6.28 \mathrm{E}-6$ ).

Beside EOQ values, the user must input the other Namelist variables common to a 11 cases: NNUCLD; DDSTIM; QFALPH (optiona1), and either AMAD or D3, D4 and D5, and the user must enter values for NR, R, UBAR, BRATE, and values for JXCAL are optiona1. For the user-input E/Q option, the only allowed values for JXCAL are D and -1 .

E/Q Values Calculated by WRAITH

The user indicates that WRAITH should calculate E/Q values by simply not including EDQ in the Namelist input. BRATE must be greater than 1 to avoid bypassing the atmospheric dispersion calculation. The variables common to al1 cases must be included in Namelist input: NNUCLD; DOSTIM; QFALPH (optional); and either AMAD, or D3, D4, and D5. Namelist input should also include those variables needed in all atmospheric dispersion calculations: NR, R, UBAR, BRATE, and JXCAL (optional). Also, the following variables are needed for $E / Q$ calculations:

PASCLS: The Pasquill Stability class: A, B, C, D, E, and F. Since PASCLS is a 1-character alphameric variable, the letter must be enclosed in quotes (Sample: PASCLS=' D').

IDPLET: An integer which determines whether or not to calculate plume depletion by dry deposition.

IDPLET $=1$ : calculate plume depletion

IDPLET=0: do not calculate plume depletion.

Default value=0, so omitting IDPLET also turns off the plume depletion calculation.

H: The height of the release in meters. If it is a ground level or vent release, a value for BDAREA should be included. For stack releases, various plume rise models may be calculated. Discussions of both cases follow.

Ground level or vent releases. WRAITH uses the methods of USNRC Regulatory Guide 1.145, which includes plume meander, to calculate plume dispersion from a ground level or vent release. This must include a value for: 
BDAREA: The smallest vertical-plane cross sectional area of the reactor building, in $\mathrm{m}^{2}$. A value of zero for BDAREA will work in the claculation, but this value must be input. If the Namelist input sets $H=D$, but omjts BDAREA, the defautt value for BDAREA is -1 , which turns off the plume meander, and calculates atmospheric dispersion as an elevated release from a height of zero. The results obtained by the two different methods may differ.

Elevated releases. Omitting BDAREA in the Namelist input turns on the elevated release calculation. $H$ is the height of the stack from which the effluent is emitted. If no plume rise correction factor is used, $H$ should be the effective stack hejght, and DELH and the other variables for calculating plume rise should be omitted from the Namelist. Otherwise, the effective stack height is found by adding the plume rise correction factor to $H$. The plume rise correction factors can be either input or calculated.

To input plume rise correction factors, include in the Namelist input:

DELH: The plume rise correction factors, in meters. The DELH array must include a value for each range, but identical values can be input easily by using the $1 * 1$ notation (DELH=10*2.7, or DELH=1.8, 2.3, 2.7, 4*2.9).

For caiculatirị tire gi!me rise correction factor, several options exist:

- Momentum-dominated plume rise:

The user must input values for two Namelist variables:

VELSTK: The velocity of the effluent leaving the stack $(\mathrm{m} / \mathrm{s})$

DIASTK: The diameter of the stack (m)

- Buoyancy-dominated plume rise:

For Pasquill stability casses A, B, C, or D (unstable to neutral):

The user should input either:

a. QHSTK: The stack's heat emission rate (cal/sec) or:

b. VCLSTK: The effluent volume flow rate $\left(\mathrm{m}^{3} / \mathrm{s}\right)$

TAIR: The ambient air temperature $\left({ }^{\circ} \mathrm{K}\right)$ and

TMPGRD: The temperature gradient of the air at the top of the stack $\left({ }^{\circ} \mathrm{K}\right)$.

For classes $E$ or $F$ (stable):

The user should input either: 
a. QHSTK

TAIR

and TMPGRD: The temperature gradient of the air at the top of the stack $\left({ }^{\circ} \mathrm{K} / \mathrm{m}\right)$. Recommended values are:

TMPGRD $=.0102$ (E class), and

TMPGRD $=.0252$ (F class).

b. VOLSTK

TAIR

TSTACK

and TMPGRD.

It should be noted that the plume rise correction can either be momentumdominated or buoyancy-dominated, or it can have both mementum and buoyancy components. WRAITH is designed to sum the two components into one correction factor, or handle either component without the other.

Summary of Namel ist Use

Table 0.1 summarizes the variables in the Namelist, defining and describing each one. Table 0.2 summarizes the use of the Namelist variables under each of the different options. Table 0.3 shows the uses of the plume rise variables for each of the options. 
TABLE D.2. Use of Namelist Variables in Atmospheric Dispersion Options

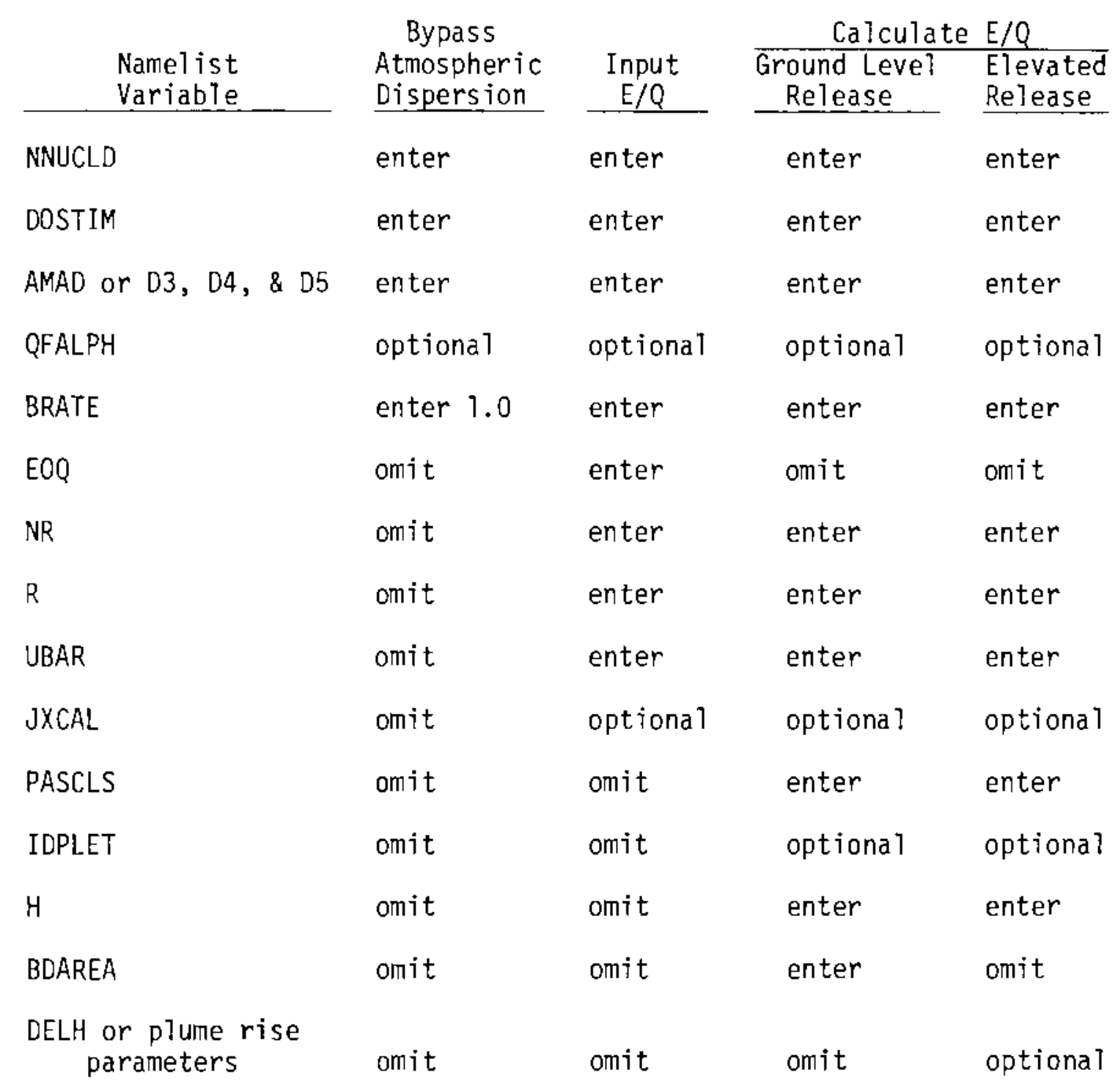


TABLE D.3. Plume Rise Correction Variabies*

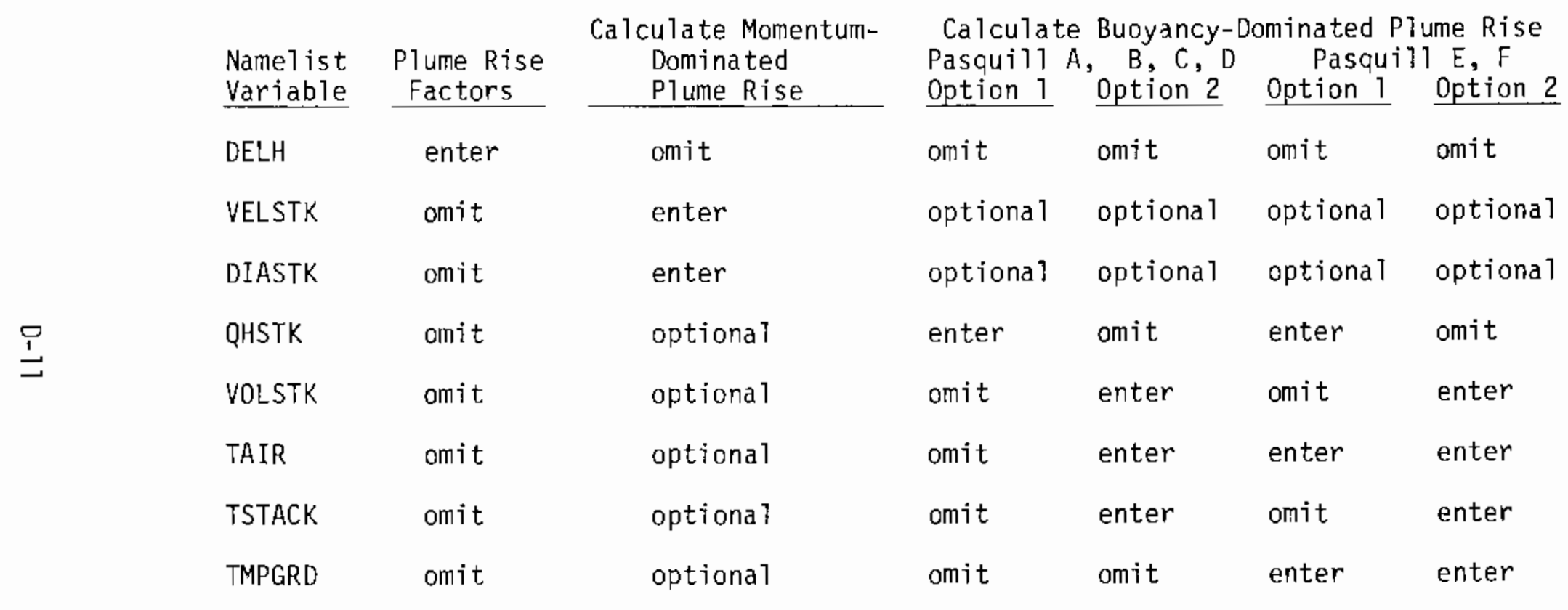

* These variables may be used only when WRAITH calculates E/Q due to elevated releases. All these variables may be omitted to turn off the piume rise correction calculation. 


\section{NUCLIDE DATA ENTRY}

Prompt message: ENTER NUCLIDE DATA

EEAAAAAAQQQQQQQQQQDDDDDDDDDDDWWWWWWWWWWYYYYYYYYYY

Variables entered: Element name, atomic weight, quantity released, percent in $D$ class, percent in $W$ class, percent in $Y$ class (one set for each nuclide requested).

Format: $\mathrm{A} 2, \mathrm{A6}, 4 \mathrm{E} 10.4$

The format must be followed exactly, or values will be misread. To help in lining up the input, the E's, A's, Q's, D's, W's and $Y^{\prime} s$ on the second line of the prompt message define the fields for each variable. The element names and atomic weights must have all characters placed in the proper columns to ensure proper reading and identification.

The last four variables are real numbers, and if their values are entered without exponents, they may be anywhere in the proper ten-space field. The decimal point must be included to avoid misreading. If a value is expressed in scientific notation (i.e., 1.23E-01), it must be right-justified--that is, the last digit of the exponent must lie in the tenth space of the field. The computer will give a prompting "greater-than" (>) for each nuclide requested.

Nuclide name: Each radionuclide is identified by a two-ltter element name, and a six-character "atomic weight." Standard one- or two-Tetter abbreviations are used for each element name, with the qualification that a one-letter name must always have its letter in the first space, with a blank in the second. To correctly identify the nuclide, the numbers in the atomic weight must be left-justified in the six-character field, with blanks filling

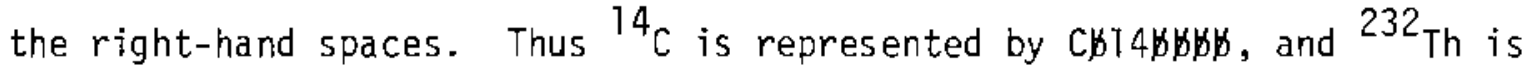

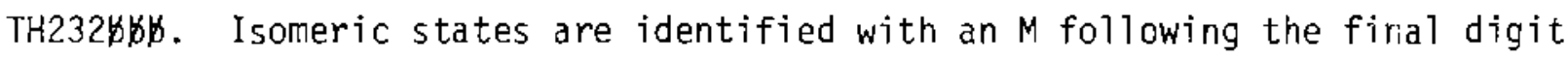

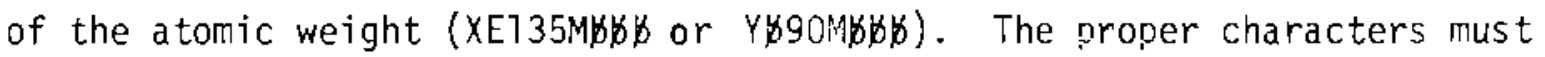
a Tways be in the correct spaces, or WRAITH will not be able to match the requested nuclide with the nuclides in its data files. If in doubt, the user can refer to a data file listing to find the proper representation of a radionuclide. 
Quantity: The quantity of each nuclide is either:

- The quantity inhaled (in microcuries) if the atmospheric dispersion calculation is bypassed, or

- The quantity released (in curies), if the atmospheric dispersion calculation is performed.

Solubility classes: The calculation of the nuclide's transport through the respiratory tract is done by the ICRP Task Group Lung Model. This model was developed for particles described by three clearance classes: D class (with a biological half life in the pulmonary region of 0.5 days), W class (with a biological half life in the pulmonary region of 50 days), and $Y$ class (with a biological half life in the pulmonary region of 500 days).

The class should be determined by the chemical form of the radionuclides. WRAITH handles each nuclide as a combination of the three classes--the user specifies the combination by inputting a value between 0 and 100 for the percentage in each clearance class. The sum of the three values must equal 100 for all nuclides except nobie gases. If the requested nuclide is a noble gas ( $\mathrm{Ar}, \mathrm{Kr}, \mathrm{Xe}, \mathrm{Rn})$, zeros must be entered for the percentages in all three classes as a flag to use inhalation dose factors for these nuclides.

There is a limitation to the number of nuclides which may be requested by a WRAITH run. The arrays are dimensioned to handle a total of 200 nuclides, which includes the decay chain members of requested nuclides. Thus the maximum number of requested nuclides would be under 100 if each one had at least one daughter.

\section{EXTERNAL DOSE FACTORS}

External dose factors are entered for each range for which JXCAL=-1. These dose factors must be taken from previous WRAITH calculations, performed with identical atmospheric conditions.

Prompt message: ENTER EXTERNAL DOSE FACTORS--START A NEW LINE FOR EACH NUCLIDE (FREE FORMAT) 
Variables entered: External dose factors (rads/Ci) for each nuclide at each range identified by JXCAL array.

Format: A1I the input dose factors for each nuclide must be entered as a group, beginning with the value for the first range. More than one 1 ine may be used for each nuclide, but data for the first range for each nuclide must begin on a new line. If input dose factors are not required for the first range (or first several ranges), but they are needed for later ranges, dummy values (not used in calculations) must be entered for the first range (or first several ranges). No values need to input for ranges after the last required input value, however.

Notes: Much computer time can be saved by inputting external dose factors which have been found by previous WRAITH calculations (see next section on external dose options). Care must be taken, however, to ensure that the proper dose factors are used. These dose factors are not the same as submersion dose factors - usually the units are different, and confusing the two can result in grief for the user. Be sure that the input dose factors were calculated for the identical atmospheric conditions--including release height, plume rise correction, and plume depletion--as those in the present calculation. Also be sure that external dose factors are input for all nuclides used in the calculation. Remember that WRAITH automatically finds the daughters for any requested nuclide. If these daughters are produced in a significant amount during the transit from release to receptor point, external dose factors will be required. The best method is to list each daughter as a requested nuclide with the quantity released equal to zero.

\section{External Dose Calculation}

Options for calculating external doses in WRAITH basically come to a choice between an expensive, precise calculation, and a cheap, approximate calculation. However, a happy medium can sometimes be used - inputting the results of a former expensive calculation to give a cheap, precise calculation. There are also cases in which the approximate calculation is as good as the expensive one. 
Calculate External Dose Factors $(J X C A L(I R)=1)$ : This is the expensive, precise option. With this option, WRAITH performs a numerical volume integration over the plume in the vicinity of the exposure point to calculate a dose factor for each photon energy group. The dose factor for a nuclide is found by reading the nuclide's photon energies and abundances from the organ data Tibrary, and suming up the energy dose factors for all the photons. This external dose factor is in units of rads per curie released, and WRAITH converts the dose factor to dose by multiplying it by the quantity released, modified by the radioactive decay or production during transit. (Note that the dose factor is multiplied by curies released, not a concentration at the receptor site.) The doses calculated are a $115 \mathrm{~cm}$ depth doses (the doses to tissue after attenuation by $5 \mathrm{~cm}$ of tissue), and only photons contribute. This method of calculating doses is especially desirable in cases where the plume is overhead, such as in an elevated release at a short range. It is also useful when the plume has not spread very far laterally or vertically, as in stable conditions, short to medium ranges. Unfortunately, the numerical integration is quite time consuming, requiring from 70 to 55 seconds of execution time per range (on the UNIVAC $3100 / 44$ ).

Use Submersion Dose Factors from a Library $(J \times C A L(I R)=0)$ : This is the cheap, approximate option. With this option, WRAITH reads the externai dose factor from the S-factor library. This dose factor was calculated assuming that the person receiving the dose was immersed in a "semi-infinite" cloud of radionuclides. (Semi-infinite means that the dimensions of the cloud are much larger than the ranges of the photons emitted by it.) This dose factor is multiplied by the radionuclide concentration at the receptor site to give the external dose, which is also the $5 \mathrm{~cm}$ depth dose. Of course, this avoids al1 the dose factor ca1culations of the previous option, with a large savings in execution time. Under unstable atmospheric conditions, at long ranges, the plume does approximate a semi-infinite cloud, and this option calculates external doses which agree with doses calculated by the previous option to within a few percent.

Input External Dose Factors $(J \times C A L(I R)=-1)$ : When this option can be used, it produces the most accurate results with minimal execution time. It can 
only be used, however, when the requested nuclides have been used in a previous WRAITH calculation at the same ranges, under exactly the same atmospheric conditions. Remember that only previously calculated dose factors can be used - submersion dose factors cannot.

\section{Selection of External Dose Option}

The user must consider cost, importance of the external component to the dose, range and atmospheric conditions, and the nature of the particles emitted by the radionuclides in the calculations. If unlimited funds are available for the calculation, the user can be sure of always getting the most accurate doses possible by using JXCAL= 1. In the more likely event that cost is important, however, other factors should be considered. If the external component to the dose is not important, such as the case in which none of the requested radionuclides enit any gammas or only weak gammas (such as ${ }^{90} \mathrm{Sr}-{ }^{90} \mathrm{Y}$ ), there is no need to calculate external dose factors. Submersion dose factors from the library would do nicely, or the user could input zeros for dose factors to give zero external doses.

There are cases in which submersion dose factors would obviously give very poor results, such as elevated releases at ranges near the stack. In other cases submersion dose factors give very good results--ground-level releases under unstable conditions at long ranges. In between these two extremes is a gray area where the user must make (hopefully) educated guesses.

The plume closely approximates a semi-infinite cloud when the plume's standard deviations $\left(\sigma_{y}\right.$ and $\sigma_{z}$ ) are both significantly greater than the mean free path in air of the highest-energy gammas emitted by material in the plume. As an example, the ${ }^{60}$ Co gammas have mean free paths in air of about 120 meters. Thus for Pasquil1 A, $\sigma_{y}=450 \mathrm{~m}$ and $\sigma_{z}=2000 \mathrm{~m}$ at a range of $2500 \mathrm{~m}$, and the semi-infinite cloud model is a fairly good approximation (the approxi1. ation improves, of course, as the range increases). For Pasquill $\mathrm{F}$ class, however, at $100,000 \mathrm{~m} \sigma_{y}=2000 \mathrm{~m}$, but $\sigma_{z}=90 \mathrm{~m}$, and the "flat" plume is not a good approximation to a semi-infinite cloud. This particular rule of thumb may be somewhat unsatisfying, since a few hand calculations must be performed before applying it, but when coupled to the other considerations, it should be a good guide for the WRAITH user. 
INSTRUCTIONS FOR RUNNING WRAITH ON THE UNIVAC 1100/44

WRAITH is designed to be run primarity in the interactive mode from a remote terminal. The user first assigns input files and the program file to his run, and (optiona17y) assigns an output file. Logical unit numbers are assigned to the data files, and then the aXQT command is typed in. During program execution, the user enters input data in response to the prompting messages printed by the code. The end of program execution is signalled by an end-of-run message, and the user can then route the output file to a printer, if he originally assigned the file to his run. There is no automatic restart option for WRAITH - the user must assign a new output file, type the OXQT command, and proceed as before.

The control cards for a typical WRAITH run:

1. QASG,UP $A^{\star} 15$.

2. OASG,A RSS*NUCDAT

3. DUSE 10. , RSS*NUCDAT.

4. @ASG, $A$ RSS ${ }^{\star} O R G D A T$

5. QUUSE $12 .$, RSS*ORGDAT

6. $A A S G, A$ RSS`FACTR

7. DUSE 14.,RSS*SFACTR

8. @ASG,A RSS*WRAITH

9. OXQT RSS*WRAITH.ABS

(interactive data entry)

10. OFREE $A^{\star} 15$

11. $\operatorname{QSYM} A^{\star} 15 .,, P R$

Notes:

Output Files: For the first WRAITH run in a runstream, statements 1,10 , and 11 are optional - if omitted, the code will automatically assign a file called 15 to the run, then route it to the line printer upon completion of execution. However, if a file called 15 already exists and is not assigned to the run, an attempt to run WRAITH without assigning an output file will result in an aborted execution with an obscure I/0 error message ("ERR MODE ERR-TYPE:02 ERR CODE:21", and more). Any output file can be routed to the printer by QSYM (statement 11), if it is OFREE'ed first (statement 10). The output file, 15, can have any qualifier in front of it, but it must be a permanently assigned file. 
Shortcut: For the first WRAITH run in a terminal session, statements 2-9 can be replaced by one command: CADD RSS*RUN. WRAITH. RSS*RUN. WRAITH is a file element containing statements 2 through 9, so typing in the OADD comriand adds a 11 these statements to the runstream, and the computer types all the responses to the commands. Thus the previous runstream could look like this:

@ASG,UP A*15

(AADD RSS*RUN. WRAITH

(interactive data entry)

OFREE $A^{\star} 15$

OSYM $\left.A^{\star}\right] 5 ., . P P$

Do not be dismayed-- when the computer responds to statement 8 with a message warning that the write key is missing --the program can still be executed.

Re-running WRAITH: In order to run WRAITH after the first execution in a terminal session, the user must first assign a new output data file, then type in the QXQT conmand, and upon termination of execution, route the output files. A typical runstream with a total of three WRAITH executions follows:

QADD RSS*RUN. WRAITH

(interactive data entry for first run)

OASG,UP $A^{\star} 15$

SNQT RSS*WRAITH.ABS

(interactive data entry for second run)

DFREE $A \star 15$

@SYM $A^{\star} 15 .,, P R$

DASG,UP $B * 15$

QXQT RSS*WRAITH.ABS

(interactive data entry for third run)

QFREE $B^{\star} 15$

OSYM B*15., , PR

Teminal Output: After all the input data is input for a WRAITH execution, the program types out a message saying that it's running. Then there is a pause while the program executes, and the user should remember that an external dose factor calculation can take a minute or more of computer execution time--thus the pause could be lengthy. Then a summary of doses at each 
range is printed out. Unfortunately, even this surmary printout can sometimes seem slow - on a 300 baud Decwriter it takes about 30 seconds per range - so a ten-range case takes 5 minutes for the summary printout. The user can avoid much of this printout by using the command: O@SKIP $n$; where $n$ is the number of lines to be skipped, $n \leq 63$. There are 14 lines per range if no quality factor is specified, 16 lines per range with a quality factor.

Appendix E includes the terminal printout for two sample cases. Running WRAITH in Batch Mode

Rather than running WRAITH from a remote terminal (in demand mode), the user may wish to run WRAITH as a batch job, either with a file that is OSTART'ed, or using a card deck. This option can be used satisfactorily, with the warning that the run card must call for $75 \mathrm{~K}$ words of memory:

@RUN WRAITH $/ 75 / / /$, BCAO00/BCA000 . USR NAME

Since the detailed file is on logical unit 15, it is not automatically included in the line printer output, and if an output file is assigned to the run, it must again be OFREE'ed and BSYM'ed after program execution.

\section{DESCRIPTION OF OUTPUT}

The line printer output (from logical unit 15) records all the input information used in the calculation, both from terminal and data libraries; calculated parameters used in the dose calculation; and the detailed results of the dose calculations. At the top of each page is a heading listing the job title (input at the terminal), the page number, and date and time of the run.

The first page of the output is the Q.A. page. It lists the titles of the data libraries used and the input data entered from the terminal, and it provides a summary of the options used in the calculations. All the input entered from the terminal, except the data in type III statements (nuclide data), are included on the Q.A. page. 
Page 2 of the output 1ists a summary of the nuclide data entered from the terminal, and information about the decay chains. The top table simply tabulates the data input concerning the nuclides requested for the run. The second table shows the decay chains for each requested nuclide. (The chains were read in from the nuclide data library.) The daughters for each requested nuclide are Tisted, and a chain ID number is assigned to each chain member. Each daughter can have up to two parents, identified by their chain ID's. The decay fraction is the fraction of parent decays which produce the particular daughter. If a zero is listed as the ID for the second parent, it means there is only one parent in the chain. If a zero is listed as the ID of the first parent, the first parent is not a direct product of the requested nuclide's decay chain. In some cases, a requested nuclide may be in the decay chain of another nuclide. It will then be listed in both places in the table, and will be used twice in the calculations, once for each capacity. The calculated doses, however, will be summed and reported only once. If a requested nuclide has no daughters, it will be listed alone under the decay chain table.

A tabie summarizing organ data follows the nuciide decay chains. This table includes the data read from the organ data library: The coefficients of the organ retention functions, the transfer fractions from blood to the organs, and the transfer fractions from the small intestine to the blood. There is a listing for each nuclide used in the run.

A compilation of S-factors follows the organ data tables. The S-factors are in rads/uCi-day; some were calculated, and others were read in from the S-factor itbrary.

If the run includes any noble gases, following the S-factor table is a table listing the internal dose factors due to inhalat in of the nuclides. These dose factors are multiplied by the quantity of the nuclide inhaled to give doses to the organs whenever the gas is inhaled. If the noble gas nucitides are daughters of other nuclides (such as ${ }^{135}$ Xe produced by ${ }^{135} \mathrm{I}$ ) which are inhaled, the gas is assumed to clear the organ in which it is produced with a biological half time of two hours.

If the atmospheric dispersion calculation is not bypassed, a table lists the parameters used in that calculation. Input values are listed, as are 
values for $E / Q$ at each range (whether input or calculated), and tables may also include $\sigma_{y}, \sigma_{z}$, plume rise correction factors, and plume depletion fractions. A table of the lung deposition fractions follows.

It should be noted that the execution time, in seconds, follows various tabies. This time is set to zero at the start of program execution, and allows the user to see how much execution time has been used up to each point. It is especially helpful in letting the user determine which options are time consuming, and should help in choosing options for future runs.

Following the lung deposition fractions, there is a table of the external dose factors. If any factors are calculated, the external dose factors by gamma energy group are listed for each range (zeros are listed under ranges with other external options). Then the external dose factors are tabulated for each nuclide at each range, and the top of each column shows how the dose factors were obtained at each range:

CALC indicates that this run calculated the dose factors $[J \times C A L(I R)=1]$;

LIB indicates athe submersion dose factors were read from the $S$-factor library $[\mathrm{JXCAL}(\mathrm{IR})=0]$;

INPUT indicates that dose factors calculated by previous WRAITH runs were input $[\mathrm{JXCAL}(\mathrm{IR})=-1]$.

Units for CALC or INPUT values are $(\mathrm{rad} / \mathrm{C} i)$; units for $L$ IB values are $\left(\frac{\mathrm{mrad} \mathrm{m}^{3}}{\mathrm{pC} i \mathrm{hr}}\right)$.

If the atmospheric dispersion calculation is bypassed, the dose calcutation results follow the lung deposition fractions. First the activity-residence times (in $\mu \mathrm{Ci}$-days) are listed for each nuclide in each organ. Then a table lists the cross-organ dose commitments for each nuclide, due to both high-LET and low-LET radiation (units are rads). On the final page are listed the "totals" for cross-organ doses: the contributions from all nuclides to each source-organ-target-organ dose are summed. Finally there is a summary of the dose to each organ, and the dose equivalent, in rems, is listed if a quality factor for alphas had been input (this table is the same as the summary listed at the terminal). 
In cases where the atmospheric dispersion calculation was performed, a set of doses is listed for each range. First a listing of the external dose due to each nuclide at the particular range is tabulated, and the activityresidence-time table follows. Then the cross-organ dose tables for the range are printed, and the suntiary table concludes the listing for each range. The user should note that the summed dose table inciudes all the cross-organ doses to each source organ, pius the $5-\mathrm{cm}$ depth doses due to external radiation from all the nuclides.

Following the dose summary for the last range, a final message indicates that the WRAITH run has been successfully completed.

The line printer output for two sample cases are reproduced in Appendix E. 
APPENDIX E

SAMPLE PROBLEMS 


\section{APPENDIX E}

SAMPLES PROBLEMS

Reproduction of Terminal Session for Sample Run 1

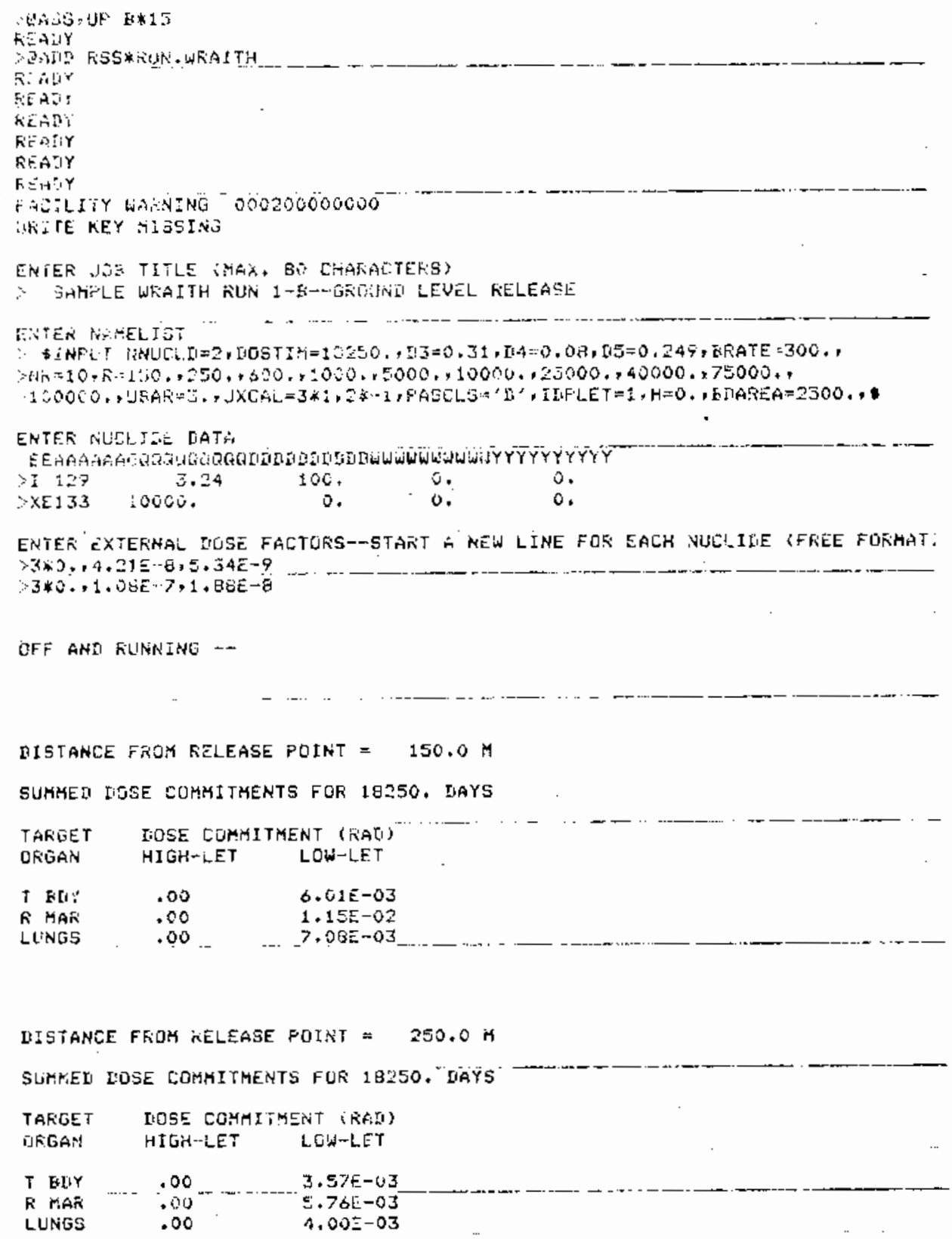




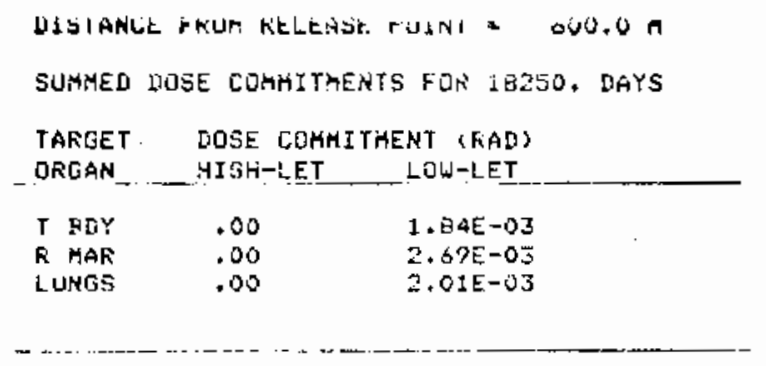

DISTANCE FNJM RELEASE POINT $=1000.0 \mathrm{H}$

SUHMED DCSE COMHITMENTS FOK 18250. LAYS

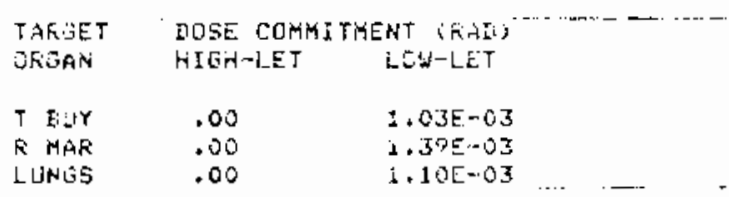

DISTARCE FROM RELEASE FOSNT $=5000.0 \mathrm{M}$

SUMKEI IOSE COMMITMEJNTS FOR 18250 . DAYS

TARGE I IOSE COKMITMENT (FIAT)

ORGAH HISH-LET LÜL-LET

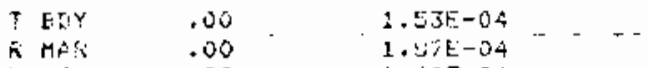

LLIt'US $\quad .00 \quad 1.30 E-04$

DISTANCE FR'OM RELEASE FOINT $=10000.0 \mathrm{M}$

SUMMED DOSE COMAITHENTE FOF 18250. DAYS

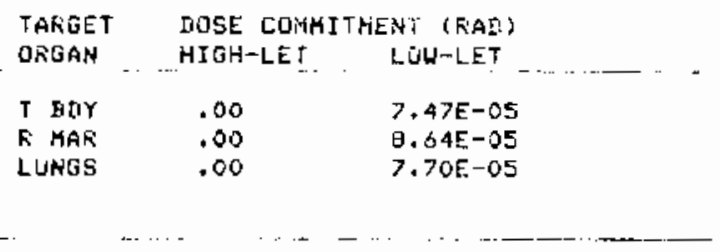

DISTANCE FROH KELEASE FOINT $=25000.0 \mathrm{H}$

SUARED DOSE COMKITHENTS FOR 18250. DAYS

\begin{tabular}{|c|c|c|}
\hline $\begin{array}{l}\text { TAKLE } \\
\text { OKOAAN }\end{array}$ & HIGH-LET & LOW-1ET \\
\hline HIIY & .00 & $1+E 9 E-05$ \\
\hline MAR & .00 & $2.195-05$ \\
\hline LUNGS & .00 & $1.75 \mathrm{E}-0 \mathrm{E}$ \\
\hline
\end{tabular}


TISTATCE FRJA RELEASE POINT $=40000.0 \mathrm{H}$

SUMMED IOSE COMYITMENTS FOF" IEZSO. TAYYS

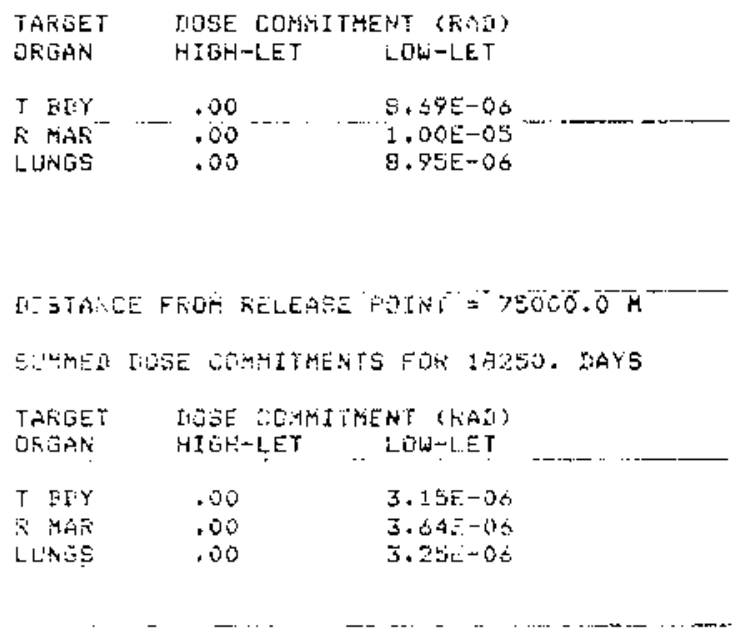

DISTANEE FROCH FIELEAUE FOINT $=100000.0 \mathrm{M}$

SLMHEII TOSE COMMITMENTS FOR 18250. IIAYS

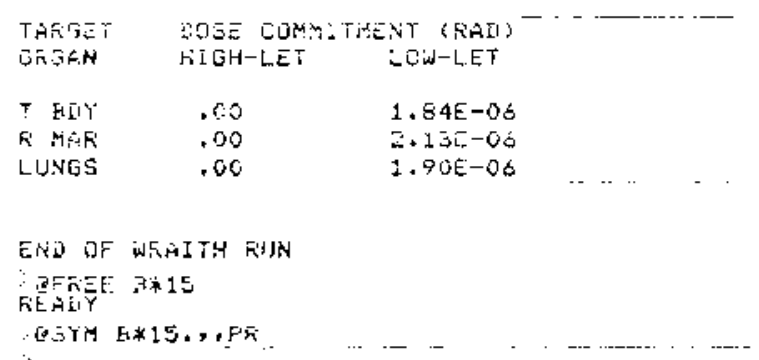




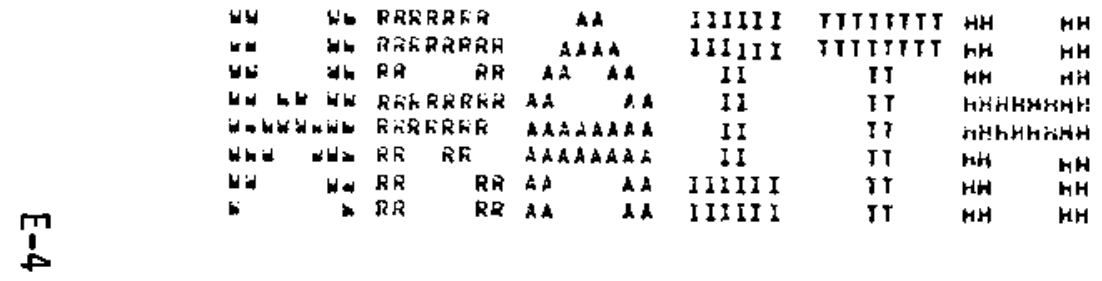

SAMLLE CAAITH RUN I-ET-GROURO LEULL FELEASE
FERARRE DU LUN NN RRRRRRTR UI UU YN NAN

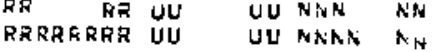
PRERRRR UU UU NA IIN NN RA RA UUS LUU R.V NAXN RR RR UUUUULULU NA NAN

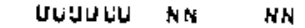
EAIE UF RUN
C3/12/8C 
WRAITH GUN --

SAMPLL WAALITH TUN 1-E--GROUNO LEVEL RELCASE

\section{*Q** O.A. PAGE ****}

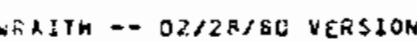

WATA GIESARIES USEU --

RACICNLELEQ LIRKAHY:

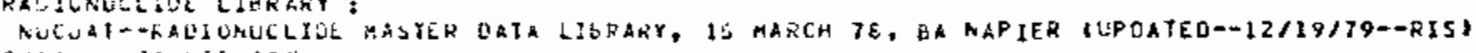

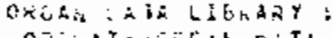

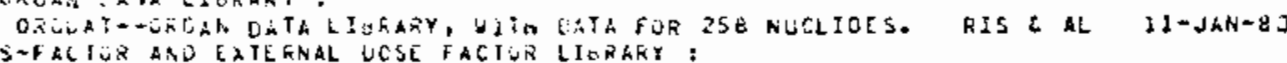

SOFACTUR ARD EATE FNAL UCSE FACTUR LIGRARY :
CAREES IRE IERS, :
150.
250.
beü.
1000.
5000
10000.
25000.
4.000
75000.100000.

AIMOSPHERIE DISPEFSIOA TATA

CALCULATEE DASEO CH --

FASGUILA STREITITY CLASS : O

$$
\text { HELEASE REIEHT: C. METEAS }
$$

AVERAEL UAB

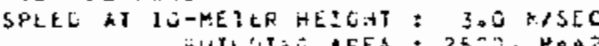

EXTERMAL EOSE factós

VENIILATION RATE : 3CO. CH*\#3/SEC

LUNG DEPOSIION VALUES

(FROM INHUT T

D3:.3100 IN -P COKPARTMENTS

Q4 : .0800 IT-B COMPARTMENT

DS: 2490 IP COMPARTMENT,

$$
\begin{aligned}
& \text { RANÜE SUUECE } \\
& \text { 550. CALCULATEC } \\
& \text { 250. CALCULATEL } \\
& \text { ECO, CatCULATE } \\
& \text { IUÉ. INPUT } \\
& \text { 5UjJ. INPUt } \\
& \text { ICECC. LIGRAR } \\
& \text { 25UDO. LIERAR } \\
& 75 E 0 \text { L LIEF⿻R } \\
& \text { IJULZO. LIGRARY }
\end{aligned}
$$

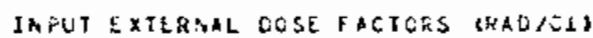

$$
\text { HARGES IMETERSI: }
$$

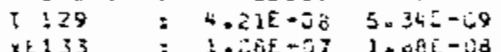

ALL LOSES CALCLLATEO IN RAOS FUK HIGH-LET AAO FOR LOW-LET RAOTATION. 


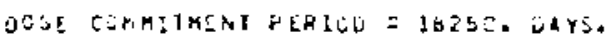

ENUYE-A LIGT UF INAUT BRELTEE CAIA IS ON THE REXY PAEEA 
WAIJH ONIN -

SAMPLE WAAITH RUN I-B--GROUNO LEVEZ RELEASE

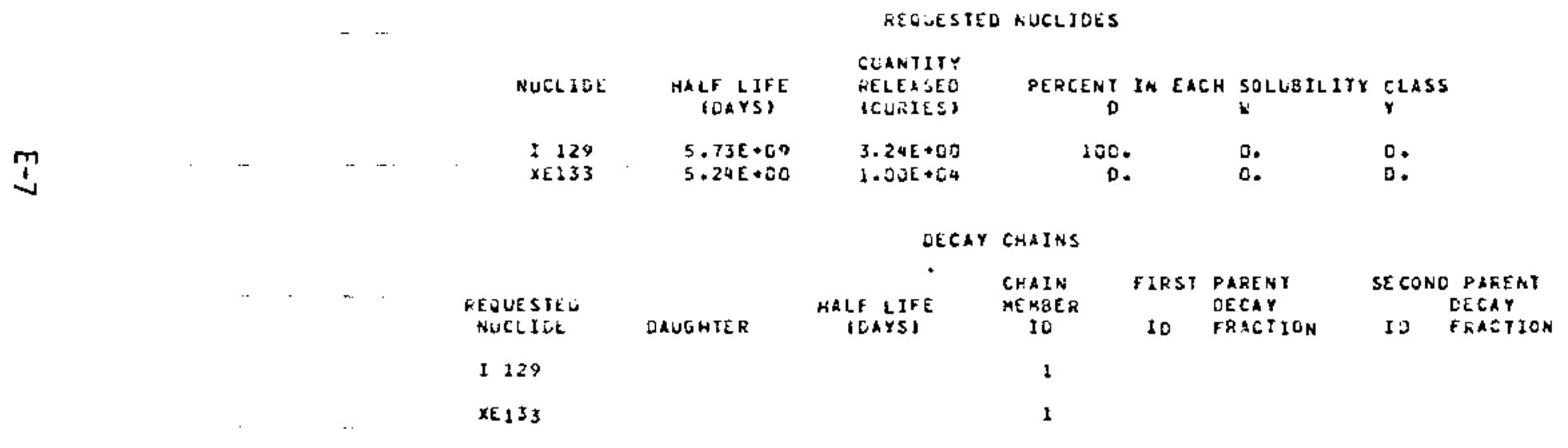

C3/12180 15.58 .42 
WKALIM NUM --

SAMPLC ERAITH RUN 1-6--6ROUNO LEVEZ FELEASE

$P A \bar{s} \bar{x} \quad 3$

$63 / 12180$

15.58 .42

SUMHERY OF CNGAN GATA

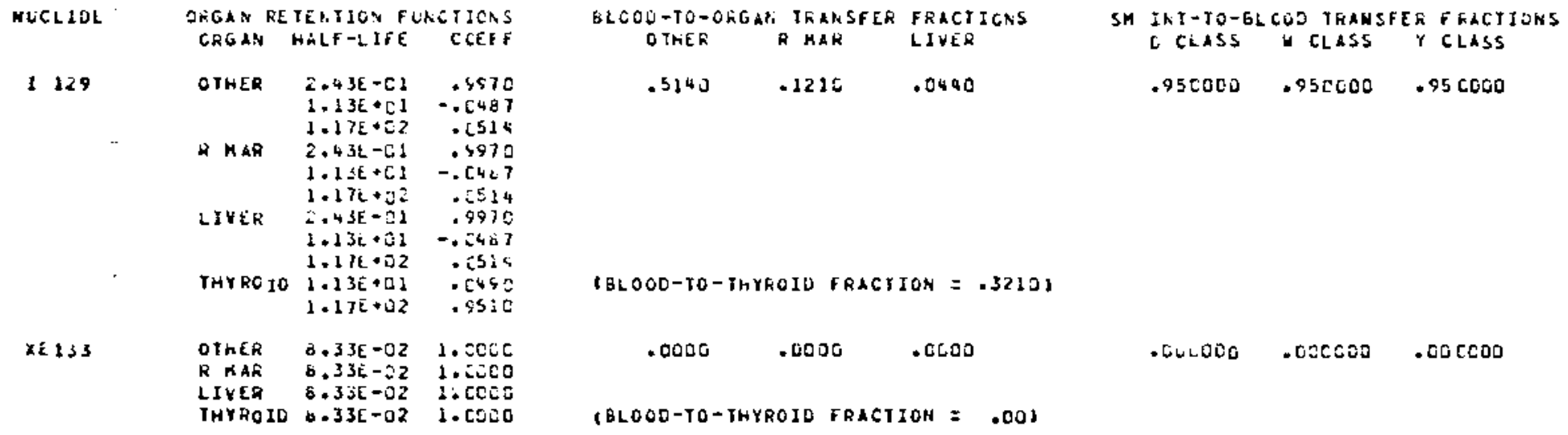




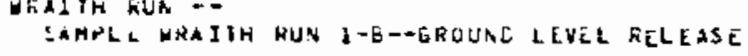

PAGE 4

$53 / 12 / 80$

15.58 .42

S-FACIGRS TRLO/H:CKO-CI-QAYS

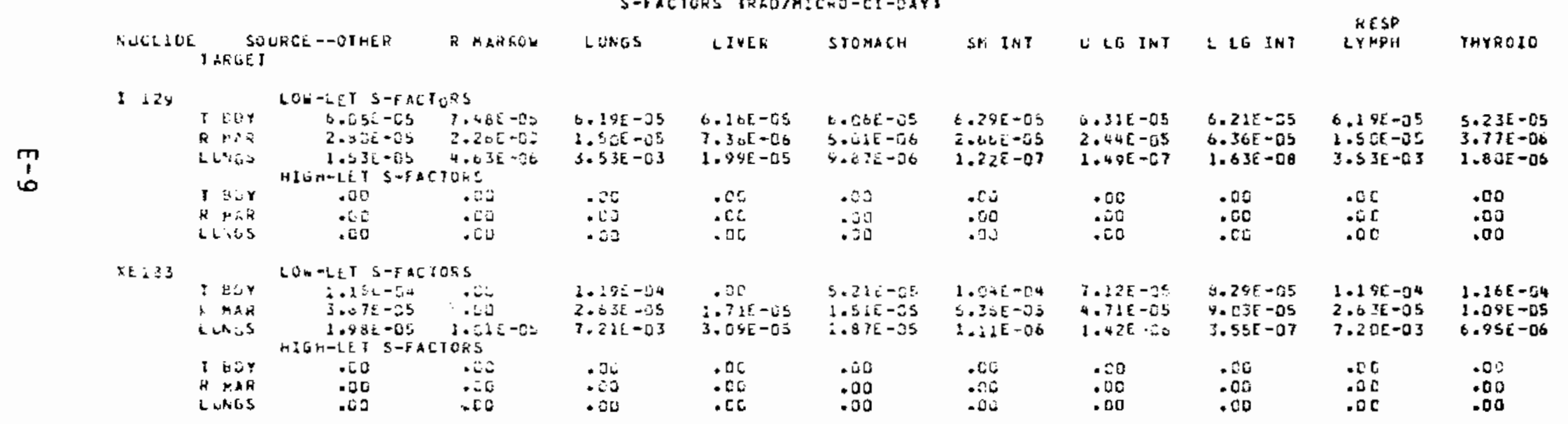


WrAlIH RUN --

SARPLZ̈ ALAITH RUK I-P-GRCURD LELEL RELEASE

PAEE 5

6312380

15.58 .42

菅

INTEERAL GOSES FCR THESE ISOTOPES ARE GALCHLATEO USINE JOSE FACTORS

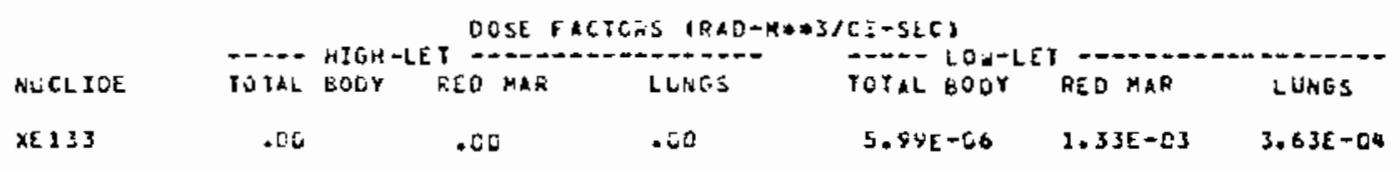

EXECUTION TIME $=0.57 \%$ SECGNOS 


\section{ATHOSFHEFIC DISPERSION CATA}

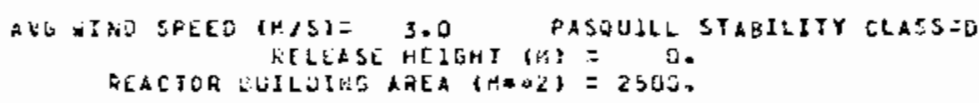

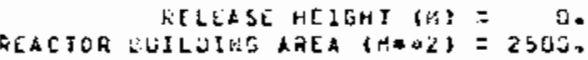

\begin{tabular}{|c|c|}
\hline $\begin{array}{l}\text { UISIAACK FKOH } \\
\text { WELEASE FI (M) }\end{array}$ & $\begin{array}{c}\text { SIGKA Y } \\
(M)\end{array}$ \\
\hline $\begin{array}{l}15 c . \\
250\end{array}$ & $\begin{array}{l}12.0 \\
19.5\end{array}$ \\
\hline 603. & 44.0 \\
\hline $\begin{array}{l}1000 . \\
5000 .\end{array}$ & $\begin{array}{r}32.0 \\
312.0\end{array}$ \\
\hline 10000. & 370.3 \\
\hline$Z E 0,:$ & 1225.5 \\
\hline 4 4üe. & :9こ0.0 \\
\hline 75030. & 3157.5 \\
\hline 130000. & $41<5.5$ \\
\hline
\end{tabular}

FGHA Z
(M)
10.8
10.5
22.0
33.0
95.0
142.5
226.0
223.3
382.7
452.5

CELIA-B DUE TO

\begin{tabular}{|c|c|}
\hline 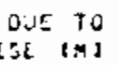 & $\begin{array}{c}E A \\
\sec : A * 3\end{array}$ \\
\hline 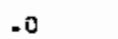 & $9.334 \sum-64$ \\
\hline & $1.7610-74$ \\
\hline - $c$ & $7.07 d \varepsilon-15$ \\
\hline .0 & $3.3976-85$ \\
\hline & $3.2 \in 7 E-J 6$ \\
\hline & $1.255 \mathrm{E}-60$ \\
\hline . 3 & 3. $7,3 E-57$ \\
\hline & $1.53 \varepsilon E-0 ?$ \\
\hline & $2.538 \mathrm{E}-\mathrm{Ca}$ \\
\hline & $5-5+1 E-08$ \\
\hline
\end{tabular}

LLAG COMPAETMENT OEPOSIIYGN FFACTIUNS

$$
\text { IFGS INPDT }
$$

C3 $=.3160$ IH-P COMPARTKESTS

DH = . CBLE (T-O COKPARTMENY

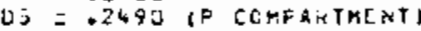

EXECLITOA TIME $=6.6 C 9$ SECOROS 
WRAJTH RUN --

SAMFLL ERAIIH WUN 1-8-GRGUAD LEVEL RELLEASE

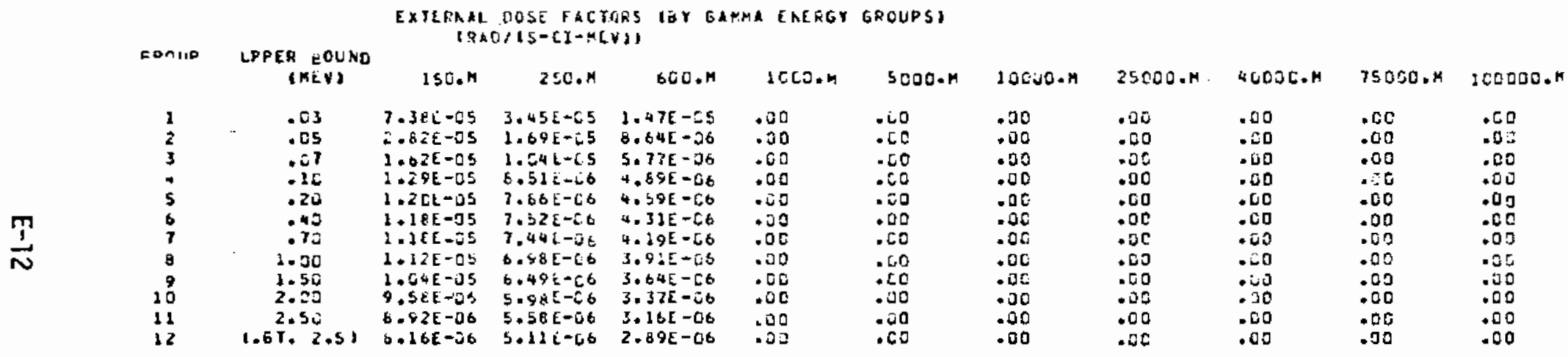

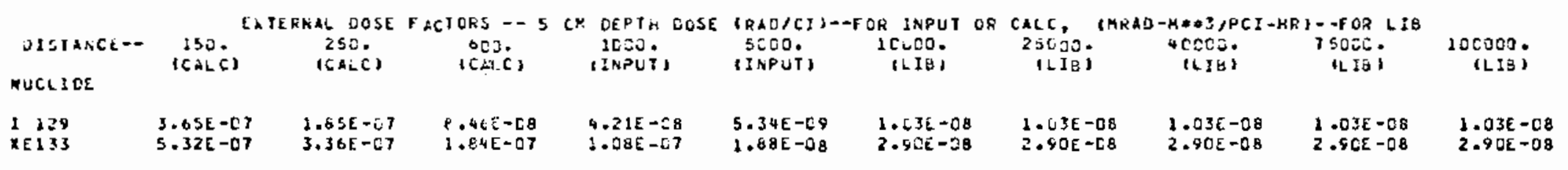

EXECUIJON TIAE $=33.172$ SECrinOS 
WFATIH KUTR--

PAGE B

$03 / 22 / 80$

15.58 .42

DISTANCE FFOM RELEASL POINT = ISC.0 H EXIERNAL DOSES

\begin{tabular}{|c|c|}
\hline RUCL IDE & $\begin{array}{l}\text { S CM DEPTH } \\
\text { OOSE IFAUST }\end{array}$ \\
\hline $\begin{array}{l}1+24 \\
x+133\end{array}$ & $\begin{array}{l}1.15 E-36 \\
5.18 E-C 3\end{array}$ \\
\hline
\end{tabular}

DOSE COMALIMENT PERIOO : 16ESJ. DAYS

\begin{tabular}{|c|c|c|c|c|c|c|c|c|c|c|c|}
\hline & \multirow{2}{*}{$\begin{array}{l}\text { YICRO-CI } \\
\text { INHALED }\end{array}$} & \multicolumn{4}{|c|}{ ACTIVITYFESIDENGE MITES } & \multicolumn{2}{|c|}{ MICRO-CI-CAYS: } & \multirow[b]{2}{*}{ U LG INT } & \multirow{2}{*}{\multicolumn{2}{|c|}{$\begin{array}{r}\text { RE SP } \\
\text { LYPPH }\end{array}$}} & \multirow[b]{2}{*}{ THYROID } \\
\hline & & OTHEK & \& MAR.RUंW & LUNCS & LIVEF & SiOHACH & SM INI & & & & \\
\hline $\begin{array}{r}128 \\
\times 2: 33\end{array}$ & $\begin{array}{l}4.22 E-31 \\
1: 270+03\end{array}$ & $\begin{array}{l}1.12 E+1000 \\
.20\end{array}$ & $\begin{array}{c}2+\$ 8 \varepsilon-31 \\
+[C\end{array}$ & $\begin{array}{c}7.395-62 \\
.00\end{array}$ & $\begin{array}{l}4.39 E-52 \\
.00\end{array}$ & $\begin{array}{l}2.72 E-03 \\
. O D\end{array}$ & $\begin{array}{l}5.44 E-04 \\
.00\end{array}$ & $\begin{array}{l}1.77 E-03 \\
.00\end{array}$ & $\begin{array}{l}3.27 E-43 \\
. \text {. }\end{array}$ & $\begin{array}{l}1.48 E-02 \\
.00\end{array}$ & $\begin{array}{l}2.345001 \\
.00\end{array}$ \\
\hline
\end{tabular}


6. OS In BUN -

SAMPLË PRAIIH RUN 1-BO-EROLAU LEVIL HELEASE

TIESTANCE FROM XELEASE POINT $=150.0 \mathrm{~K}$

CROSS ORGAN DOSE COMMITMEATS FUR 13250.0 DAYS (RAOSS

\begin{tabular}{|c|c|c|c|c|c|c|c|c|c|c|c|}
\hline NuCe IOE & T+2. & UKCE - JTHEA & R MAFFC: & LUt.as & LIVER & ITOHACH & SM INT & U LG INT & $\downarrow L G$ INT & $\begin{array}{l}\text { RESP } \\
\text { LYMFH }\end{array}$ & THYROIO \\
\hline I 1 is & $\begin{array}{l}1 \cos x \\
x \operatorname{Min} x \\
L \text { this }\end{array}$ & 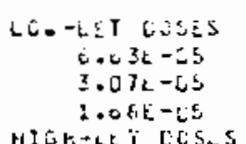 & $\begin{array}{l}1.45 E-55 \\
5.63 E-E 4 \\
1.2 .2 E-66\end{array}$ & $\begin{array}{l}4.57 E-C S \\
1.12 E-C C \\
2.6 Z E-04\end{array}$ & $\begin{array}{l}5.7 i \varepsilon-0 s \\
8.915-07 \\
5.87 \varepsilon-06\end{array}$ & $\begin{array}{l}2.55 E-E 2 \\
1.30 E-E B \\
2.69 E-08\end{array}$ & $\begin{array}{l}2.4 \div E-60 \\
1.45 E-3 d \\
6.6+2-13\end{array}$ & $\begin{array}{l}1.12 E-07 \\
4.30 E-08 \\
2.62 E-10\end{array}$ & $\begin{array}{l}2.03 E-37 \\
2.05 E-07 \\
5.32 E-11\end{array}$ & $\begin{array}{l}9.13 E-D 7 \\
2.21 E-07 \\
5.21 E-0 S\end{array}$ & $\begin{array}{l}7.02 E-04 \\
2.42 E-0.5 \\
2.42 E-05\end{array}$ \\
\hline & 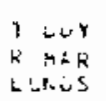 & 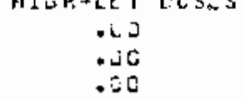 & $\begin{array}{l}.20 \\
.00 \\
.00 \\
.00\end{array}$ & $\begin{array}{l}.00 \\
.00 \\
.00\end{array}$ & $\begin{array}{l}.80 \\
.00 \\
.02\end{array}$ & כ0 & $\begin{array}{l}.00 \\
.00 \\
.00\end{array}$ & $\begin{array}{l}.50 \\
.00 \\
.00\end{array}$ & $\begin{array}{l}.60 \\
.00 \\
.00\end{array}$ & $\begin{array}{l}.0= \\
.00 \\
.00\end{array}$ & $\begin{array}{l}.02 \\
-0,00 \\
.00\end{array}$ \\
\hline$X E\{3$ X & 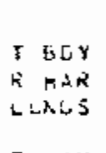 & 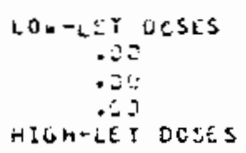 & $\begin{array}{l}.6 c \\
.80 \\
.05\end{array}$ & $\begin{array}{l}2.53 E-65 \\
5.62 E-03 \\
1.53 E-03\end{array}$ & $\begin{array}{l}.60 \\
.00 \\
.00\end{array}$ & 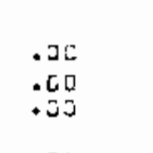 & $\begin{array}{l}.00 \\
.00 \\
.00\end{array}$ & $\begin{array}{l}-\infty 0 \\
.00 \\
-00\end{array}$ & $\begin{array}{l}.00 \\
.00 \\
.00\end{array}$ & $\begin{array}{l}-50 \\
.00 \\
=00\end{array}$ & $\begin{array}{l}.00 \\
.00 \\
.00\end{array}$ \\
\hline & $\begin{array}{l}T \text { LOY } \\
\text { R MAR } \\
\text { L LNGS }\end{array}$ & $\begin{array}{l}-20 \\
.00 \\
.00\end{array}$ & $\begin{array}{l}.60 \\
. i 2 \\
. i 0\end{array}$ & $\begin{array}{l}-50 \\
.00 \\
.00\end{array}$ & 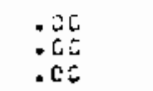 & $\begin{array}{l}.00 \\
.00 \\
.00\end{array}$ & $\begin{array}{l}.00 \\
.00 \\
.00\end{array}$ & $\begin{array}{l}.00 \\
.00 \\
.00\end{array}$ & $\begin{array}{l}.0 \tilde{~} \\
.00 \\
.00\end{array}$ & $\begin{array}{l}.00 \\
.00 \\
.00\end{array}$ & $\begin{array}{l}.00 \\
.00 \\
.00\end{array}$ \\
\hline
\end{tabular}


WRAITH FUN -

SAMPLE -RAITH RUN 1-B--6ROUHO LEVEL RËLEASE

PAGE 10

03122180

$25.58 \cdot 42$

DISTANCE FRGM RELEASE POINT = 1SC.0.

EKOSS ORIAN DOSE COHYITKEATS FUR 78250 . C OAYS GEAES

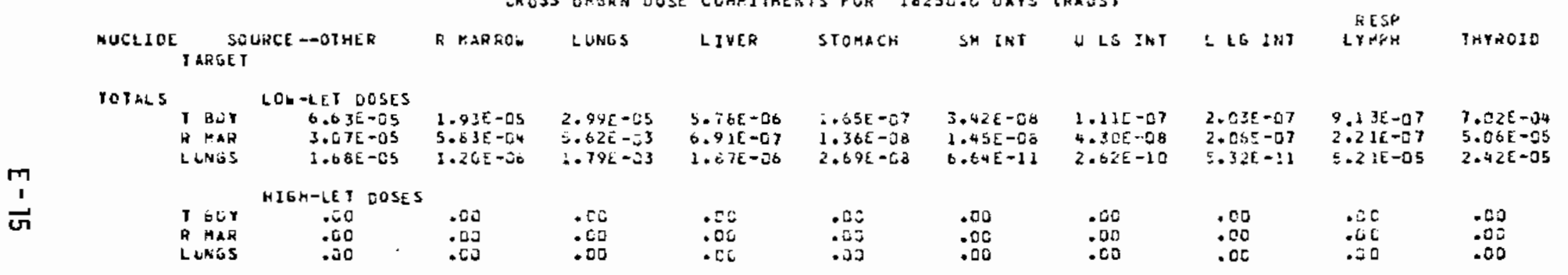

SUMMEO DOSE COMMITMENTS FOR IS25C. DAYS

\begin{tabular}{|c|c|c|}
\hline TARGET & \multirow{2}{*}{\multicolumn{2}{|c|}{$\begin{array}{l}\text { DOSE COMMETHENT TEAUI } \\
\text { HIGH-LEJ LWW LLEJ }\end{array}$}} \\
\hline 8GA: & & \\
\hline 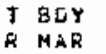 & $\begin{array}{l}.05 \\
.50\end{array}$ & $\begin{array}{l}\text { 6.ELE-GS } \\
1.15 E=02\end{array}$ \\
\hline LUNES & .00 & $7.28 E=23$ \\
\hline
\end{tabular}

EXECUTION IIHE $=33.290$ SECONGS 
DISTANCE FFOH RLIEASE PCINY = ZSE.J

$\frac{m}{a}$

EXTERNAL DOSE

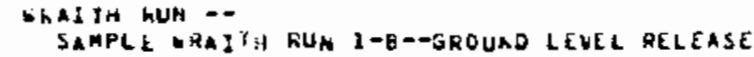

DAGS 21

$03 / 22 / 80$

15.58 .42

$\begin{array}{lc}\text { SWCLIDE } & \text { SCM DCPIH } \\ \text { DOSE IRADES } \\ 1129 & 5.70 E-C Z \\ \times[133 & 3.24 E-03\end{array}$

COSE COMHIMENJ PERIOO : 18250. JAYS

ACTIVITY-RESBTENCE IBNES MICRO-CI-DAYSJ

\begin{tabular}{|c|c|c|c|c|c|c|c|c|c|c|c|}
\hline \multirow[b]{2}{*}{ NUCLIOE } & \multirow{2}{*}{$\begin{array}{l}\text { KICEC-CI } \\
\text { INHALED }\end{array}$} & \multicolumn{7}{|c|}{ (1) } & \\
\hline & & OYHER & K Mhkkow & LUNGS & AIVEA & STOMACH & $S H$ INT & U LG INT & $L$ LG INT & LYMPA & THYRDIO \\
\hline $\begin{array}{r}125 \\
E: 33\end{array}$ & $\begin{array}{l}1.65 E-111 \\
5.09 \varepsilon+212\end{array}$ & $\begin{array}{l}4.4 \mathrm{OE}-\mathrm{Cl} \\
. \mathrm{CO}\end{array}$ & $\begin{array}{l}1.54[-51 \\
.50\end{array}$ & $\begin{array}{l}2.96 E-C 2 \\
.00\end{array}$ & $\begin{array}{l}\text { 3. } 77 E-02 \\
.0 E\end{array}$ & $\begin{array}{l}1.09 E-03 \\
.00\end{array}$ & $\begin{array}{c}2+18 \varepsilon-0 Q \\
.00\end{array}$ & $\begin{array}{c}\text { T. } \\
.08 E-04\end{array}$ & $\begin{array}{l}1.31 E-03 \\
.00\end{array}$ & $\begin{array}{l}5.92 E-03 \\
.00\end{array}$ & $\begin{array}{l}5.39 E \cdot 00 \\
.00\end{array}$ \\
\hline
\end{tabular}


WRAIIM RUN --

SAMPLE RAITH RUN I-E-GROUNO LEVEL RELEASE

PAGE 12

$[3 / 22 / 83$

15.50 .42

DISTANCE FROM RELEASE POIHT $=2 S 0.0 \mathrm{n}$

CROSS ORGAN ROSE CORHITMENTS FOR IEZ5O.0 OAYS (RAOS)

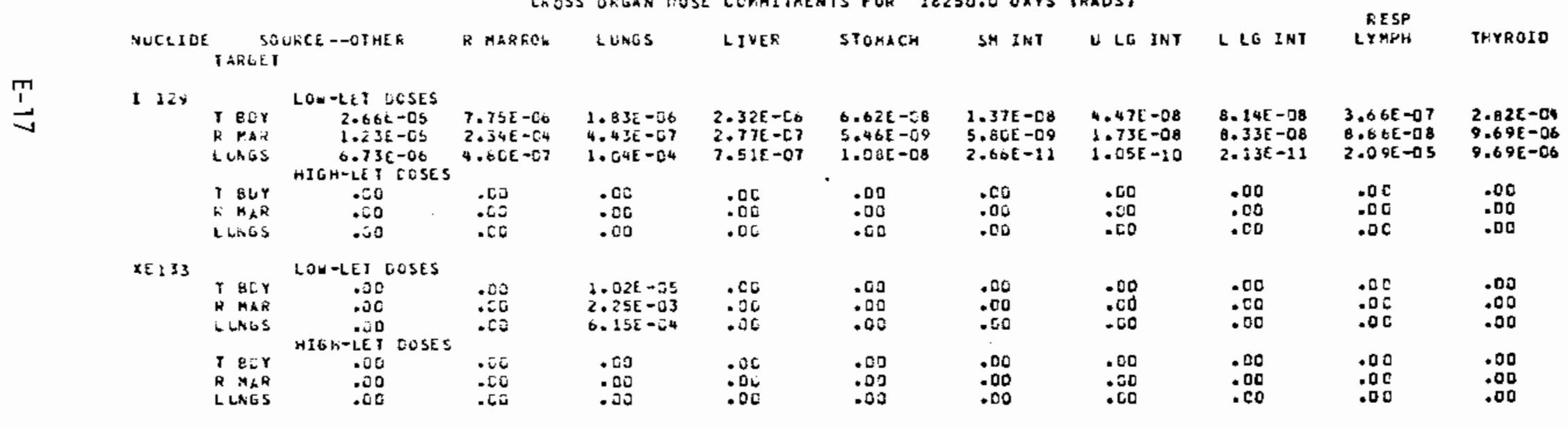


DRAITH RUA -

SAMPLC WRAIIH RUN 1-E-GROUAD LEVEL RELEASE

DISTANGE FROM RELEASE POJHT $=250.0 \mathrm{M}$

(NOSS ORGAN COEE COMMITMENIS FOR 18250.0 JAYS (RAOS)

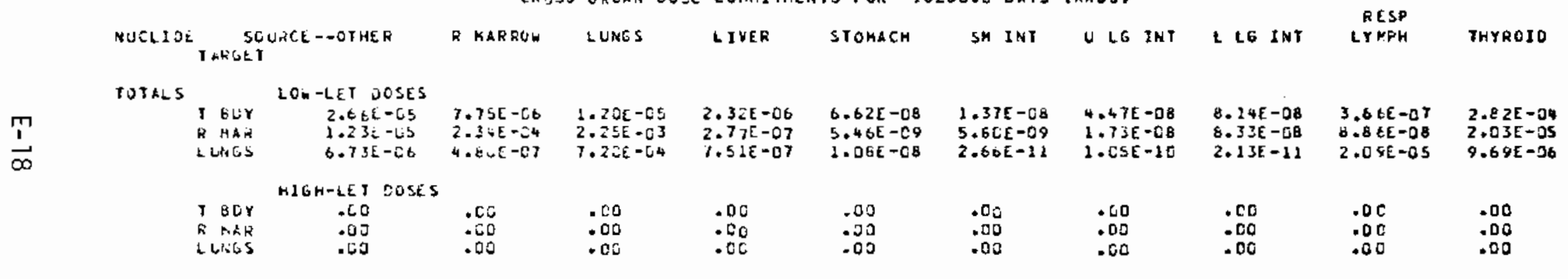

SUMMEO DOSE COMMIYHENTS FOF 18250 . DAYS

\begin{tabular}{|c|c|c|}
\hline TAR'SE T & \multirow{2}{*}{\multicolumn{2}{|c|}{$\begin{array}{l}\text { QOSE COMMITHENY (KAD) } \\
\text { HIGH-LET LOY LEY }\end{array}$}} \\
\hline CK 5 & & \\
\hline T $20 y$ & . Ca & 3 \\
\hline URGS &.$c 0$ & 4. \\
\hline
\end{tabular}

EXECUIION TIME $=33.409$ SECONDS 
WRAITH RUN =-

SAMPLK bRAITH RUN I-b--GROIIND LEYEL RELEASE

DISTANCE FEON RELEASE POIHT = $600.0 \mathrm{~m}$

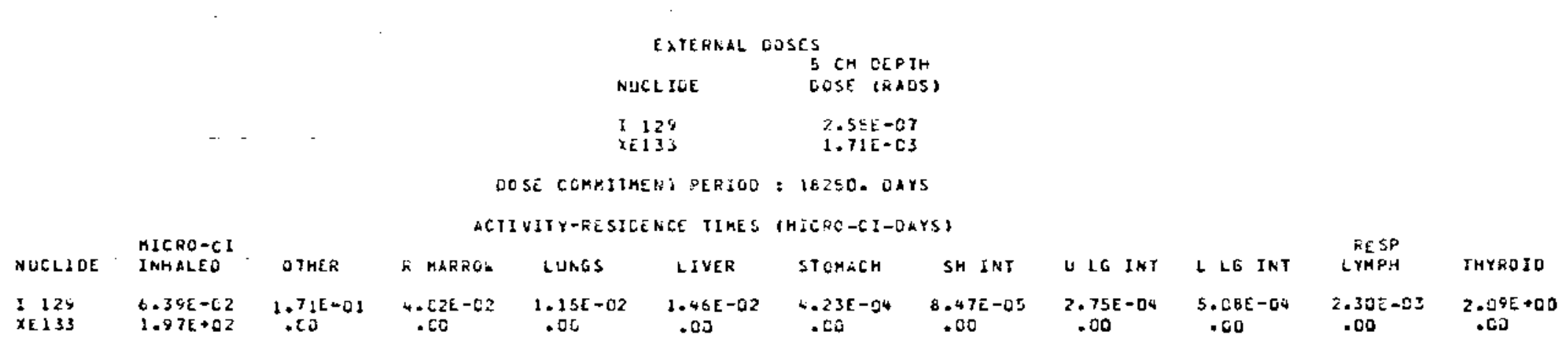


WRAIIH RUM =-

SAMPLE MRAITH RUN I-B--GROUNO LEVEL RELEASE

PAGE IS

$63 / 22 / 50$

15.58 .42

LiSTANCE fFOn RELLASE POINT $=$ 600.C $\mathrm{K}$

CRGSS ORGAN DOSE COMHITMENTS FOR 16250.0 DAYS IRAOS:

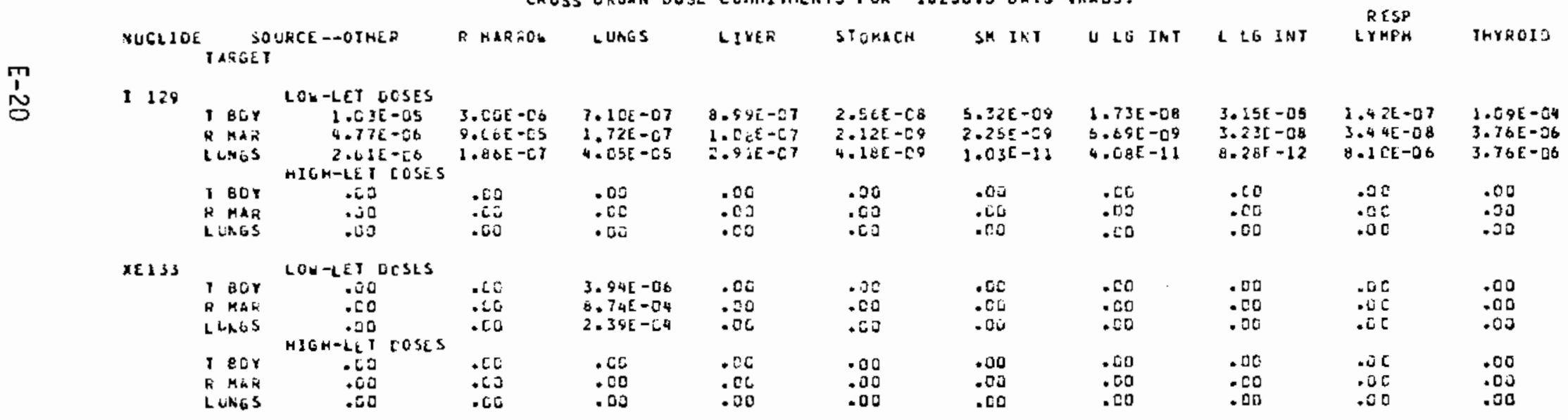


WRAIIH RUR --

SAMPLE LRAIIH RUN T-8--GROUND LEVEL RELEASE

OISTANCE FFUA FELEASE POINT $=000.0 \mathrm{H}$

CFDSS ORGAN OCSE CORITHENTS TOE 18Z50.0 DAYS (RADS)

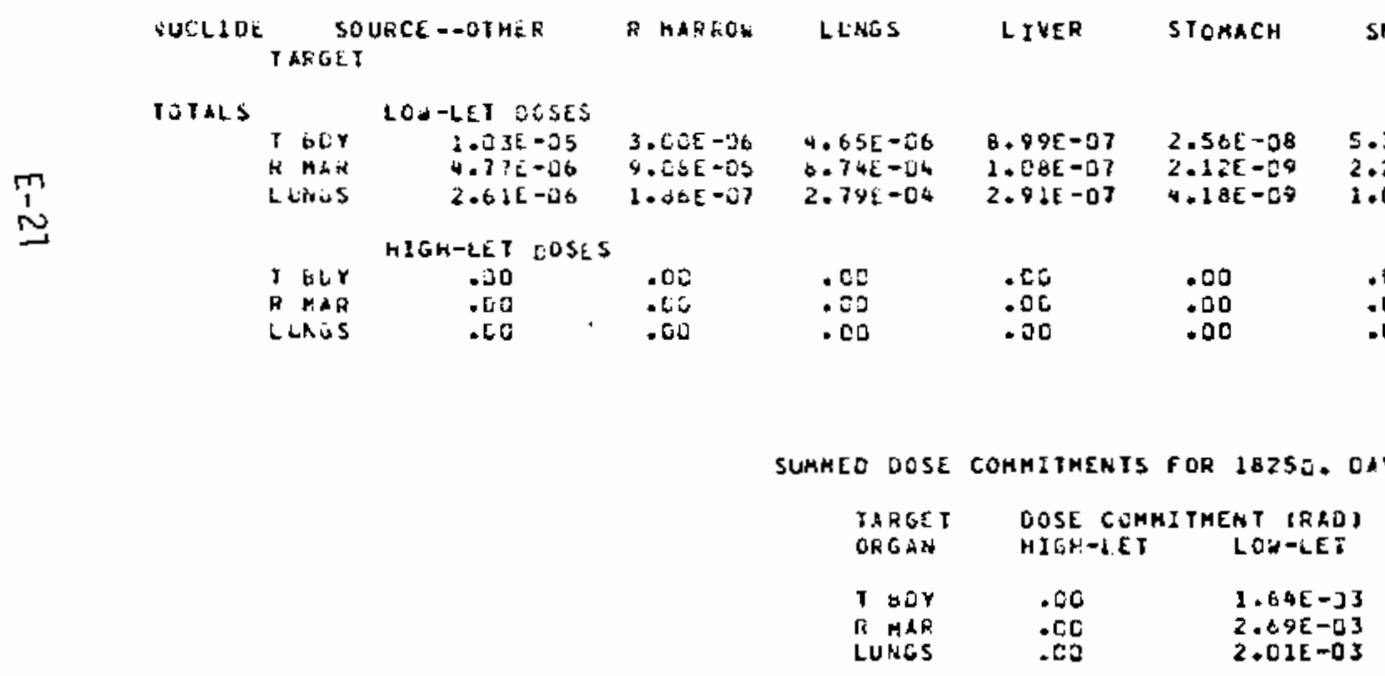

PAGE 16

$03 / 12 / 80$ $15 \cdot 5^{8} \cdot 42$

INT ULG INT L LG INT LYMPH

LYMPH THYROID

$\begin{array}{lllll}.32 E-09 & 1.73 E-08 & 3.15 E-08 & 1.42 E-07 & 1.09 E-04 \\ .25 E-09 & 6.69 E-09 & 3.23 E-08 & 3.44 E-0 B & 7.87 E-06 \\ 2.03 E-11 & 4.08 E-11 & 8.28 E-12 & 8.12 E-06 & 3.76 E-06\end{array}$

$\begin{array}{lllll}.00 & .00 & .00 & .00 & .00 \\ .00 & .00 & .00 & .00 & .00\end{array}$

EXECUTION TIME $=33.527$ SEFONOS 
- AlTir flí -

SAMPLL ARAIIH SUN ITEAGROUI.:

- Vi i RELEASE

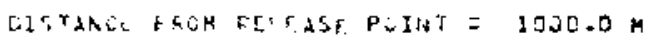

EXTGRTAL WOSES ES CH DEPTH

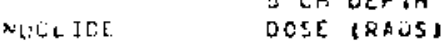

$\begin{array}{ll}52-2 & 2.23 E-0 i \\ 253 & 9.72 E-O^{4}\end{array}$

WOSE COMMITMENT FERIOD : 18250. OAYS

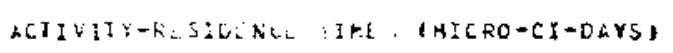

\begin{tabular}{|c|c|c|c|c|c|c|c|c|c|c|c|}
\hline GULLILL & 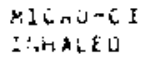 & ¿THÉR & $\because$ MAKKOL & LUNGS & $\therefore$ I LE K & STOMACIA & SM INT & $U L G$ INT & $L d O$ INT & $\begin{aligned} R E S P \\
\text { LYHPH }\end{aligned}$ & THYROIO \\
\hline $\begin{array}{l}x \quad 129 \\
x \in 1 \leq 3\end{array}$ & $\begin{array}{l}2.118-62 \\
8.362+31\end{array}$ & $\begin{array}{l}7.2+t=0 i \\
\text { - [D }\end{array}$ & $\begin{array}{l}1.70[-0 ? \\
.00\end{array}$ & $\begin{array}{l}4.67 E-[3] \\
.00\end{array}$ & $\begin{array}{l}t .2 C E-0 z \\
.0 E\end{array}$ & $\begin{array}{l}1.8 \mathrm{EE}-04 \\
\cdot 0 \mathrm{E}\end{array}$ & $\begin{array}{l}3.59 \varepsilon-05 \\
.00\end{array}$ & $\begin{array}{l}1.16 E-04 \\
. C O\end{array}$ & $\begin{array}{l}2.16 E-04 \\
.00\end{array}$ & $\begin{array}{l}9.745-04 \\
.00\end{array}$ & $\begin{array}{l}8.86 E-01 \\
.00\end{array}$ \\
\hline
\end{tabular}

PAGE 1T

C3/1280 15.58 .42 
VRAITH KUH --

SAMPLE BRAIIH RUN 1-R-GROUND LEVEE RECEASE

DISTLRE FFÓM RELEASE PCINT $=1000.0 \mathrm{~N}$

CKOS: ORGAN DOEE COMMIIMENTS FOH $16250 . \mathrm{C}$ DAYS (RAOS)

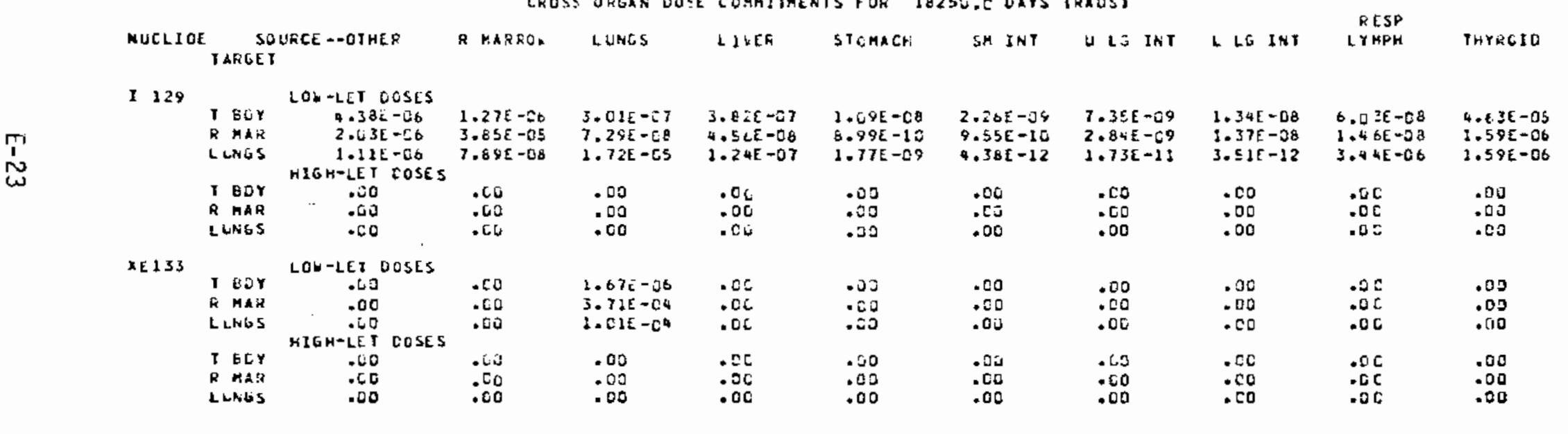

PRGe 13

$03152106 \quad 15.58 .92$ 
WRALTH RUN -

SAMPLE WRAITH RUN 1-B--GROUNO LEVEL RELEASE

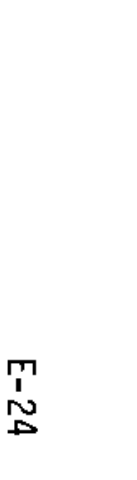

PAGE 19

$[3 / 12 / 80$

15.58 .42

DISTANCE FPom RLLäSE POINT = I0OC.0 $\mathrm{M}$

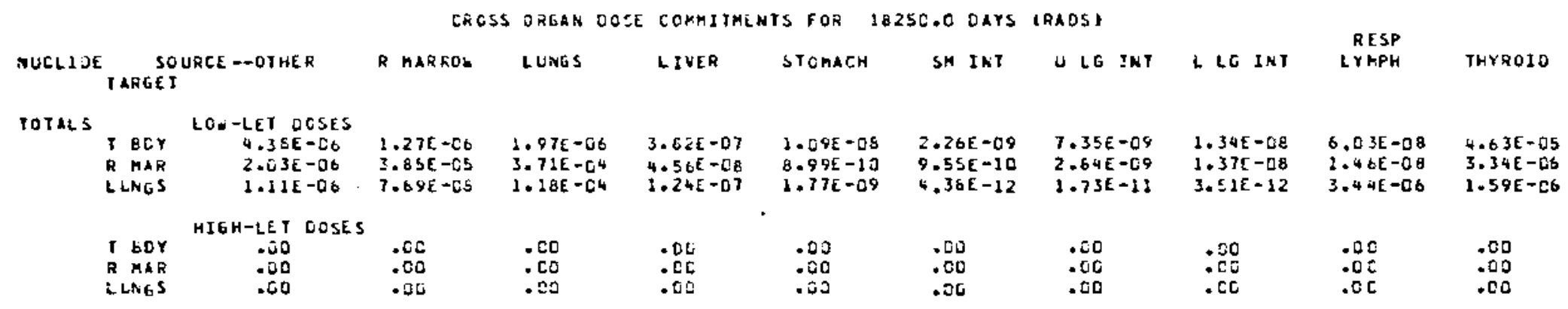

SUKMEO DOSE COMMITKENTS FOR 18250. DAYS

\begin{tabular}{|c|c|c|}
\hline $\begin{array}{l}\text { TARGE T } \\
\text { OFGAN }\end{array}$ & HIGH-LET & LOW-LEY \\
\hline $\begin{array}{l}\text { BDY } \\
\text { R KAE } \\
\text { LUNGS }\end{array}$ & $\begin{array}{l}.60 \\
.60 \\
.60\end{array}$ & $\begin{array}{l}2.0 .5 E-C^{3} \\
1.38 E-03 \\
1=10 E-03\end{array}$ \\
\hline
\end{tabular}

EXECUIIGN YIME $=33.645$ SECONDS 
WRAIIH WLNA-D
SATPLL KRAIIH KUN 1-8--GROUND LELEL RELEASE

EISTANCE FFOR KELEASE PUINT = EOJC.O $\mathrm{k}$

$$
\begin{aligned}
& \text { S CM DEPIH } \\
& \text { DOSE ITALS } \\
& \begin{array}{ll}
1129 & 1.37 E-C b
\end{array}
\end{aligned}
$$

\begin{tabular}{|c|c|c|c|c|c|c|c|c|c|c|c|}
\hline \multicolumn{12}{|c|}{ HIORG-C: } \\
\hline$J C L\}$ & $\begin{array}{l}\text { HICRG-CI } \\
\text { IASACEL S }\end{array}$ & CTKER & A MREROK & LUNES & LIVER & STOMACH & SH INT & $\| L G$ IN & $L$ LG INT & $\begin{array}{l}\text { RESP } \\
\text { LYMPH }\end{array}$ & THYROID \\
\hline $\begin{array}{r}124 \\
6133\end{array}$ & $\begin{array}{l}2.516-03 \\
7.14 E+00\end{array}$ & $\begin{array}{l}0.71 E-03 \\
.00\end{array}$ & $\begin{array}{l}1.58 E-0 Z \\
.00\end{array}$ & $\begin{array}{l}4.51 \mathrm{E}-\mathrm{CH} \\
.00\end{array}$ & $\begin{array}{l}5.74 E-04 \\
.00\end{array}$ & $\begin{array}{l}1.66[-05 \\
.00\end{array}$ & $\begin{array}{l}3.33 k-06 \\
.00\end{array}$ & $\begin{array}{l}2 . \cos -05 \\
.00\end{array}$ & $\begin{array}{l}2.00 E-05 \\
.00\end{array}$ & $\begin{array}{l}9.03 E-05 \\
.00\end{array}$ & $\begin{array}{l}8.21 \mathrm{E}-02 \\
.00\end{array}$ \\
\hline
\end{tabular}

OOSE COMMITMENT PLR1OD: 1EZ:O. DKYS

ACTIVITY-RESIDENCE TIKES AHIERC-CI-EAYS
PAGE 20

$63 / 12180$

15.58 .42

00 
QRALTH NUST -2

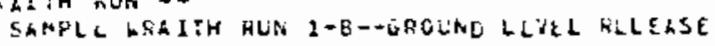

PAGE 21

$[3 / 1 \geqslant 180$

25.56 .42

DUSTANCE FROM RELEASE POINT $=5000.0 \mathrm{~K}$

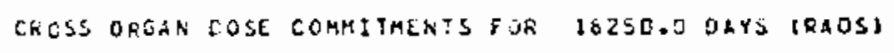

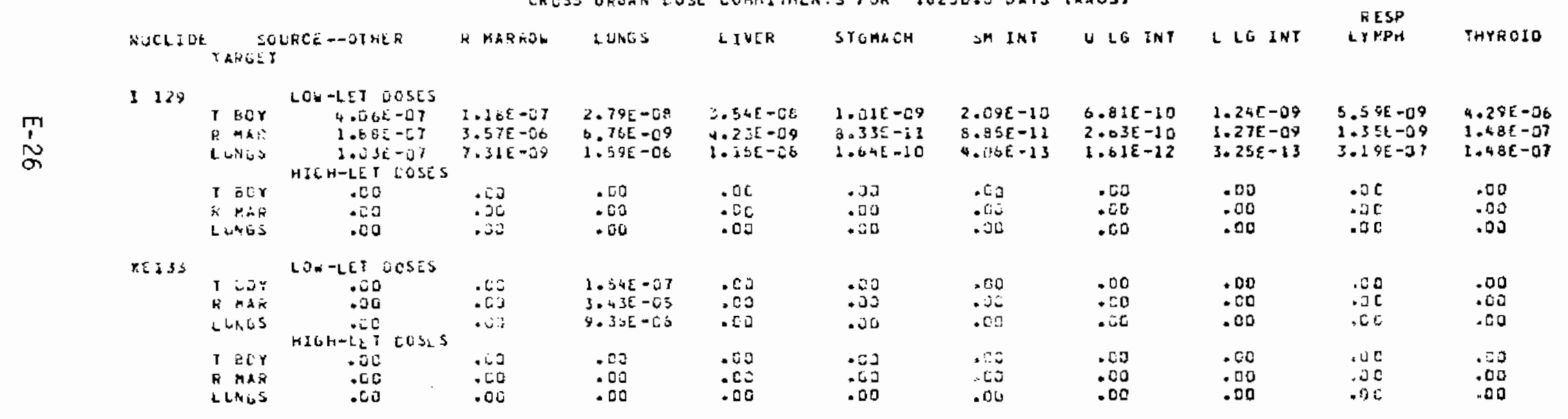


WRAITH RUM -
SAMPLE HRAIH RUN I-G--GROUND LCVEL RELEASE

PAGE 22

$[3 / 12180 \quad 15.50 .42$

Gistance Grom release PGint = SOGG.0 $\mathrm{K}$

CROSS ORLAN DOSE COMMITHENTS FOH 18250.0 OAYS IRAOS\}

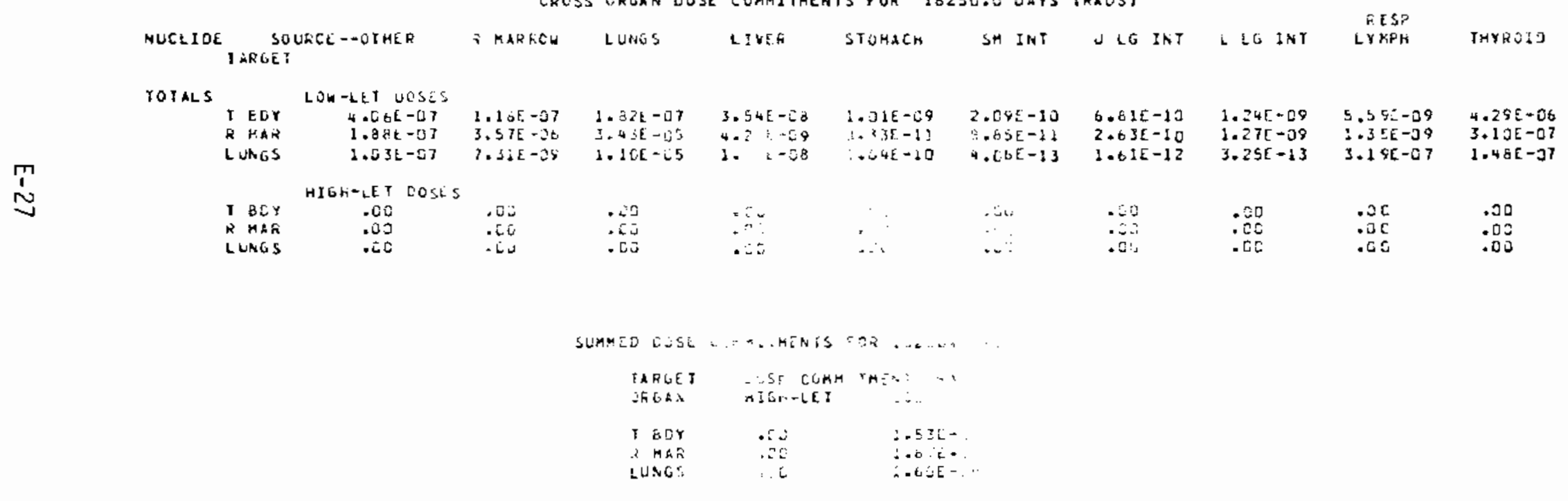

EXECUIION THHE $=$ IJ.704 SECONOS 
VRAITK KUM =-
SAMPLE YRAITH RUK I-G-GROURO LEVEL RELEASE

WISTANCE FROM RELEASE POINT $=10000.0 \mathrm{~m}$

$\underset{1}{\infty}$

$$
\begin{aligned}
& \text { EXIERNAL DOSES } \\
& \text { NUCLIDE } \\
& \text { DOSE OEPIH } \\
& \text { I } 129 \\
& \text { XEI33 }
\end{aligned}
$$

\begin{tabular}{|c|c|c|c|c|c|c|c|c|c|c|c|}
\hline$\pi$ & $\begin{array}{l}\text { MICRO-CI } \\
\text { INHALED }\end{array}$ & OTHER & R HARROX & LuMGS & LIVER & SYOPACH & SM INI & U LG INT & $L L E$ INT & $\begin{array}{l}R E S P \\
L Y M P H\end{array}$ & THY ROXD \\
\hline $\begin{array}{r}128 \\
6133\end{array}$ & $\begin{array}{l}8.8 W E-C W \\
2.3 Z E+Q D\end{array}$ & $\begin{aligned} 2 & -36 E-03 \\
. & =0\end{aligned}$ & $\begin{array}{l}5.56 E-04 \\
.00\end{array}$ & $\begin{array}{l}1.59 \varepsilon=04 \\
.00\end{array}$ & $\begin{array}{l}2.02 E-04 \\
.00\end{array}$ & $\begin{array}{c}5.26 \mathrm{E}-06 \\
.00\end{array}$ & $\begin{array}{l}1.17 \overline{\mathrm{E}}-06 \\
.00\end{array}$ & $\begin{array}{l}3.805-06 \\
.00\end{array}$ & $\begin{array}{l}7.03 E-06 \\
.00\end{array}$ & $\begin{array}{l}3.3 \text { \& } 2-05 \\
.00\end{array}$ & $\begin{array}{l}2.89 E-C Z \\
.00\end{array}$ \\
\hline
\end{tabular}

DOSE COMAITMENT PERIOD : 18250. DAYS

ACIIVITY-RESIDENCE IIMES IMICRO-CI-OAYS)
PAGE 23

$63 / 12 / 90$ 15.58 .42 
WRAITH RLA --

SAMPLL WRAIJH RUN 1-B-FGOUNO LEYEL RELEASE

CISTANCE FFOA RELEASL POINY $=1$ COOC.O $\mathrm{H}$

CROSS ORGAN DOSE COKMITMENTS FGR 2625L.O DAYS (RADS)

\begin{tabular}{|c|c|c|c|c|c|c|c|c|c|c|c|c|}
\hline \multirow{5}{*}{$\begin{array}{l}T \\
1 \\
N \\
6\end{array}$} & MUELIDE & $\begin{array}{r}\text { SO } \\
\text { I LAGE }\end{array}$ & URCE - -GTHEF & $R$ AARROO & LUNGS & LIVER & STOMACH & SH INT & $\nu$ LG INJ & $\angle 2 G$ INT & $\begin{array}{r}\text { RESP } \\
\text { LYMPH }\end{array}$ & THYRGJD \\
\hline & I $: 28$ & $\begin{array}{l}T \text { EEY } \\
R \text { MAK } \\
L U N E S\end{array}$ & $\begin{array}{c}\text { COW-LET OOSES } \\
1.4 j E-J 7 \\
6.61 i-G 8 \\
3.61 E-C \theta \\
\text { HIGT-LET LODES }\end{array}$ & $\begin{array}{l}4.16 E-0 b \\
1.20 E-C 0 \\
2.57 E-09\end{array}$ & $\begin{array}{l}9.83 E-69 \\
2.38 E-69 \\
5.638-07\end{array}$ & $\begin{array}{l}1.23 E-C B \\
1.49 E-C 9 \\
i .03 E-C 9\end{array}$ & $\begin{array}{l}3.55 E-10 \\
2.93 E-11 \\
5.78 \varepsilon-12\end{array}$ & $\begin{array}{l}3.37 E-21 \\
3.11 E-11 \\
1.43 E-13\end{array}$ & $\begin{array}{l}2.40 E-10 \\
9.26 E-12 \\
5.65 E-13\end{array}$ & $\begin{array}{l}4.37 E-10 \\
4.47 E-10 \\
2.15 E-13\end{array}$ & $\begin{array}{l}1.97 E-09 \\
4.76 E-10 \\
1.32 E-07\end{array}$ & $\begin{array}{l}1.51 E-06 \\
5.20 E-C 8 \\
5.20 E-08\end{array}$ \\
\hline & & $\begin{array}{l}\text { T EUY } \\
\text { R MAE } \\
\text { CLNES }\end{array}$ & $\begin{array}{l}\times 0 \\
.00 \\
.00\end{array}$ & $\begin{array}{l}. \text { CE } \\
\text {. CJ } \\
. \mathrm{CO}\end{array}$ & $\begin{array}{l}.05 \\
.00 \\
.05\end{array}$ & $\begin{array}{l}.00 \\
.00 \\
.00\end{array}$ & $\begin{array}{l}.00 \\
.20 \\
.00\end{array}$ & $\begin{array}{l}.00 \\
.00 \\
.00\end{array}$ & $\begin{array}{l}.60 \\
. \mathrm{ct} \\
.60\end{array}$ & $\begin{array}{r}.00 \\
.00 \\
.00\end{array}$ & $\begin{array}{l}.06 \\
.05 \\
.06\end{array}$ & $\begin{array}{l}.02 \\
.00 \\
.00\end{array}$ \\
\hline & $x E: 3\}$ & $\begin{array}{l}Y \text { SOY } \\
\text { E MAK } \\
\text { LUAOS }\end{array}$ & 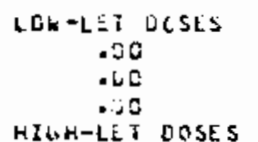 & $\begin{array}{l}.02 \\
.20 \\
.00\end{array}$ & $\begin{array}{l}5.42 E-08 \\
1.25 E-05 \\
3.29 E-66\end{array}$ & $\begin{array}{l}.00 \\
.00 \\
.00\end{array}$ & $\begin{array}{l}.00 \\
.00 \\
.00\end{array}$ & $\begin{array}{l}.50 \\
.00 \\
.00\end{array}$ & $\begin{array}{l}.00 \\
.00 \\
.00\end{array}$ & $\begin{array}{l}.00 \\
.00 \\
.00\end{array}$ & $\begin{array}{l}.00 \\
.0 \mathrm{C} \\
.0 \mathrm{C}\end{array}$ & $\begin{array}{l}.00 \\
.00 \\
.00\end{array}$ \\
\hline & & $\begin{array}{l}\text { T TEK } \\
\text { E MAA } \\
\text { LLNES }\end{array}$ & $\begin{array}{l}.00 \\
.00 \\
.00\end{array}$ & Ju & $\begin{array}{l}.00 \\
.02 \\
.06\end{array}$ & $\begin{array}{l}.05 \\
.00 \\
.00\end{array}$ & $\begin{array}{l}.00 \\
.00 \\
.00\end{array}$ & $\begin{array}{l}.90 \\
.00 \\
.00\end{array}$ & $\begin{array}{l}.00 \\
.00 \\
.00\end{array}$ & $\begin{array}{l}.00 \\
.00 \\
.00\end{array}$ & $\begin{array}{l}.05 \\
.05 \\
.00\end{array}$ & $\begin{array}{l}.00 \\
.00 \\
.00\end{array}$ \\
\hline
\end{tabular}

PAGE 24

C3/12/80 15.58 .42 
WEATIH RUR --

SAMPLE YRAITH RUN 1-E-OGROUNE LEVEL RELEASE

OISIANCE FFOM RELEASE POINT $=10000.0 \mathrm{M}$

CIOSS ORLAN DOSE COMHITHEAS FOR 18250.0 OAYS (RADS)

\begin{tabular}{|c|c|c|c|c|c|c|c|c|c|c|c|}
\hline A.SCLIDL & T TREE? & 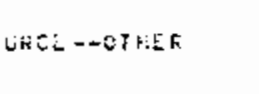 & R MARTOU & LUNG: & LIVER & STOHACH & SM INI & 4 L6 INI & L LG INT & $\begin{array}{l}\text { RESP } \\
\text { LYMFH }\end{array}$ & JHYROSD \\
\hline TOTALS & $\begin{array}{l}1 \text { BOY } \\
R \text { MAR } \\
\text { L tilios }\end{array}$ & $\begin{array}{c}\text { LOW -LEX DCSES } \\
1.43 E-07 \\
6.61 E-C 8 \\
3.61 E-05\end{array}$ & $\begin{array}{l}4.155-68 \\
1.205-66 \\
2.575-58\end{array}$ & $\begin{array}{l}6.41 E-08 \\
1.20 E-55 \\
3.25 E-56\end{array}$ & $\begin{array}{l}1.25 E-C 8 \\
1.45[-69 \\
4.03 E-09\end{array}$ & $\begin{array}{l}3.55 E-10 \\
2.93 E-12 \\
5.78 E-11\end{array}$ & $\begin{array}{l}7.37 \varepsilon-11 \\
3.11 E-11 \\
1.43 \varepsilon-13\end{array}$ & $\begin{array}{l}2.40 E-10 \\
9.26 E-11 \\
5.65 E-13\end{array}$ & $\begin{array}{l}4.37 E-10 \\
4.47 E-10 \\
1.15 E-13\end{array}$ & $\begin{array}{l}1.97 E-\square 9 \\
4.76 E-10 \\
1.12 E-07\end{array}$ & $\begin{array}{l}1.51 E-06 \\
1.09 E-07 \\
5.20 E-06\end{array}$ \\
\hline & $\begin{array}{l}1 \text { ECr } \\
2 \text { MAR } \\
\text { LUNGS }\end{array}$ & 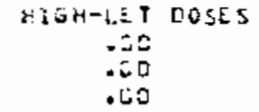 & $\begin{array}{l}.60 \\
.05 \\
.00\end{array}$ & $\begin{array}{l}: 00 \\
: 00 \\
: 00\end{array}$ & $\begin{array}{l}.52 \\
\text { CE } \\
.00\end{array}$ & $\begin{array}{l}.52 \\
.00 \\
.00\end{array}$ & $\begin{array}{l}.00 \\
.00 \\
.00\end{array}$ & $\begin{array}{l}.50 \\
.00 \\
.00\end{array}$ & $\begin{array}{l}.00 \\
.00 \\
.00\end{array}$ & $\begin{array}{l}.00 \\
.00 \\
.00\end{array}$ & $\begin{array}{l}.00 \\
.00 \\
.00\end{array}$ \\
\hline
\end{tabular}

SLMKEO DOSE COMMIIMEN IS TOA 18250 . OAYS

\begin{tabular}{|c|c|c|}
\hline $\begin{array}{l}\text { TARGEY } \\
\text { CRGEN }\end{array}$ & $\begin{array}{l}\text { ECSE COHH } \\
\text { HICH-LE }\end{array}$ & $\begin{array}{l}E N T \text { (RANU) } \\
\text { LEW-LET }\end{array}$ \\
\hline T EOY & $\therefore 0$ & $7.47[-05$ \\
\hline R MAR & .00 & $E \cdot \cos -25$ \\
\hline LU:ALS & ס0 & $7.70 E-05$ \\
\hline
\end{tabular}

$03 / 12 / 80 \quad 15.58 .42$

PAGE 25 


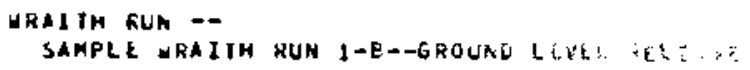

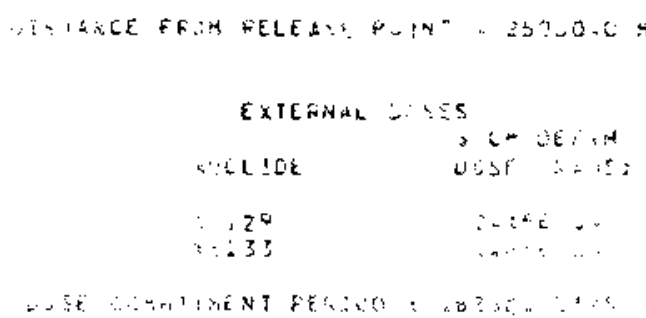

\begin{tabular}{|c|c|c|c|c|c|c|c|c|c|c|c|c|}
\hline NUCLIOE & $\begin{array}{l}\text { MICRC-CI } \\
\text { INARLEC }\end{array}$ & OTHER & 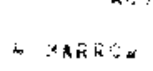 & . & 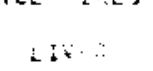 & $\because \sin 20$ & $\therefore: 4:$ & $\because 26$ & $:$ & $\vdots L G \cdots:$ & CXM & $\therefore \ldots$ ars \\
\hline $\begin{array}{l}1229 \\
X E 133\end{array}$ & $\begin{array}{l}2.2 \in E-04 \\
8.80 E-02\end{array}$ & 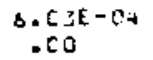 & $=a t-34$ & 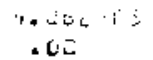 & 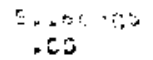 & 1. & $\cdots$ & $\begin{array}{l}3.70 t \\
.00\end{array}$ & $y$ & $\begin{array}{c}1.7: 0 . \quad \ldots \\
.00\end{array}$ & a. & 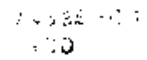 \\
\hline
\end{tabular}


YRAI IH WUM -

SAGPLE AAAIJH RUY 1-B-OGROUND LEVEL RELEASE

DISTANCE FROK RELLASE POINT = 25OJO.0 H

CROSS ORGAN OCSE CORMITEETS FOA IEZ50.0 OAYS (RAOSI

\begin{tabular}{|c|c|c|c|c|c|c|c|c|c|c|c|}
\hline \multirow{3}{*}{ ד } & $\begin{array}{r}\text { E SOSGT } \\
\text { SO }\end{array}$ & UACE - -DTHER & R MAAROH & L UNGS & LIVER & STOHACH & SM INT & U LG INT & L LG INT & $\begin{array}{l}R E \leqslant P \\
\text { LYH>H }\end{array}$ & THYROID \\
\hline & $\begin{array}{l}\text { T BOP } \\
\text { S MAR } \\
\text { LUNGS }\end{array}$ & $\begin{array}{c}\text { LOL -LET DOSES } \\
\text { 3.65E-OQ } \\
1.69 E-08 \\
9.22 E-0 Y \\
\text { HIEH-LET DOSS }\end{array}$ & $\begin{array}{l}1.06 E+08 \\
3.21 E=07 \\
6.57 E-10\end{array}$ & $\begin{array}{l}2.51 E-09 \\
6.07 E-10 \\
1.43 E-C 7\end{array}$ & $\begin{array}{l}3.16 E-0.9 \\
3.8 C E-10 \\
1.03 E-08\end{array}$ & $\begin{array}{l}9.06 E-11 \\
7.49 E-12 \\
1.4 a E-11\end{array}$ & $\begin{array}{l}1.06 E-12 \\
7.95 E-12 \\
3.65 E-14\end{array}$ & $\begin{array}{l}6.12 E-11 \\
2.37 E-11 \\
1.44 \bar{c}-13\end{array}$ & $\begin{array}{l}1.11 E-10 \\
1.14 E-10 \\
2.92 E-14\end{array}$ & $\begin{array}{l}5.02 E-10 \\
1.21 E-10 \\
2.86 E-0.0\end{array}$ & $\begin{array}{l}3.85 E-07 \\
1.33 E-08 \\
1.23 \varepsilon-38\end{array}$ \\
\hline & $\begin{array}{l}\text { I EOY } \\
\text { R MAR } \\
\text { LUASS }\end{array}$ & $\begin{array}{l}.00 \\
.00 \\
.00\end{array}$ & $\begin{array}{l}.00 \\
.00 \\
.00\end{array}$ & $\begin{array}{l}.00 \\
.0 J \\
.00\end{array}$ & $\begin{array}{l}.05 \\
.06 \\
.00\end{array}$ & $\begin{array}{l}.00 \\
.00 \\
.00\end{array}$ & $\begin{array}{l}.00 \\
.00 \\
.00\end{array}$ & $\begin{array}{l}.00 \\
.00 \\
.00\end{array}$ & $\begin{array}{l}.00 \\
.00 \\
.00\end{array}$ & $\begin{array}{l}.00 \\
.00 \\
.00\end{array}$ & $\begin{array}{l}.00 \\
.00 \\
.00\end{array}$ \\
\hline$x\{133$ & $\begin{array}{l}\text { T EDY } \\
\text { R MAR } \\
\text { LUAGS }\end{array}$ & $\begin{array}{c}\text { LOW-LEI DCSES } \\
\text {-GO } \\
.00 \\
.00 \\
\text { WIGH-LET DOSES }\end{array}$ & $\begin{array}{l}. \mathrm{CO} \\
. \mathrm{CC} \\
. \mathrm{CO}\end{array}$ & $\begin{array}{l}1.37 E-C 8 \\
3.05 E-C 6 \\
8.32 E-67\end{array}$ & $\begin{array}{l}.0 \mathrm{C} \\
.0 \mathrm{OC} \\
.0 \mathrm{C}\end{array}$ & $\begin{array}{l}.00 \\
.00 \\
.00\end{array}$ & $\begin{array}{l}.00 \\
.00 \\
.00\end{array}$ & $\begin{array}{l}.00 \\
.00 \\
.00\end{array}$ & $\begin{array}{l}.05 \\
.00 \\
.00\end{array}$ & $\begin{array}{l}.00 \\
.00 \\
.00\end{array}$ & $\begin{array}{l}.00 \\
.00 \\
.00\end{array}$ \\
\hline & $\begin{array}{l}\text { T } 50 Y \\
\text { R MAR } \\
\text { L LAGS }\end{array}$ & $\begin{array}{l}.00 \\
.00 \\
.00\end{array}$ & $\begin{array}{l}.00 \\
.00 \\
.00\end{array}$ & $\begin{array}{l}.00 \\
.00 \\
.00\end{array}$ & $\begin{array}{l}.00 \\
.00 \\
.00\end{array}$ & $\begin{array}{l}.00 \\
.00 \\
.00\end{array}$ & $\begin{array}{l}.00 \\
.00 \\
.00\end{array}$ & $\begin{array}{l}.00 \\
.00 \\
.00\end{array}$ & $\begin{array}{l}.00 \\
.00 \\
.00\end{array}$ & $\begin{array}{l}.0 C \\
.05 \\
.05\end{array}$ & $\begin{array}{l}.00 \\
.00 \\
.00\end{array}$ \\
\hline
\end{tabular}


DRAITH FUN -

SAMPLL KHAITH RUN 2-B-TGROUND LEVEL RELEASE

DISTANCE FROH RELEASL POINT $=25000.0 \mathrm{n}$

CHOSS ORGAN DOSE COMPIIHENTS FOR 3250.0 DAYS GRASI

\begin{tabular}{|c|c|c|c|c|c|c|c|c|c|c|c|}
\hline NUCLIOE & $\begin{array}{r}50 \\
12 R 0 E 1\end{array}$ & URCE - OTHEA & R MARROL & LUNGS & LIVER & STOMACH & SH INY & $U$ LG IAT & L LG INT & $\begin{array}{r}\text { RESP } \\
\text { LYRPH }\end{array}$ & THYROID \\
\hline TOTRLS & $\begin{array}{l}1 \text { Bor } \\
R \text { HAk } \\
\text { LASGS }\end{array}$ & $\begin{array}{r}\text { LOW-LET DOSES } \\
3.05 E-2 S \\
1.04 E-C S \\
9.22 E-09\end{array}$ & $\begin{array}{l}1.005+08 \\
3.21 E-07 \\
0.57 E-10\end{array}$ & $\begin{array}{l}1.62 E-C 8 \\
3.05 E-06 \\
9.76 E-67\end{array}$ & $\begin{array}{l}3.18 E-69 \\
3.5 L E=10 \\
1.03 E-69\end{array}$ & $\begin{array}{l}9.0 E E-11 \\
7.48 E-12 \\
1.45 E-11\end{array}$ & $\begin{array}{l}2.8 \partial E-11 \\
7.95 E-12 \\
3.65 E-14\end{array}$ & $\begin{array}{l}6.22 E-11 \\
2.37 E-11 \\
1.44 E-13\end{array}$ & $\begin{array}{l}1.12 E-10 \\
1.14 E-10 \\
2.92 E-14\end{array}$ & $\begin{array}{l}5 . C 2 E-10 \\
1.21 E+10 \\
2.6 B E-08\end{array}$ & $\begin{array}{l}3.86 E-07 \\
2.78 E-C 8 \\
1.33 E-08\end{array}$ \\
\hline$\omega$ & $\begin{array}{l}1 \text { SOY } \\
\text { R MAR } \\
\text { L UNGS }\end{array}$ & $\begin{aligned} \text { HIEH-LET OOSES } \\
\text {.EO } \\
. \mathrm{OD} \\
. \mathrm{ODO}\end{aligned}$ & $\begin{array}{l}.00 \\
.00 \\
.00\end{array}$ & $\begin{array}{l}.00 \\
.50 \\
.00\end{array}$ & 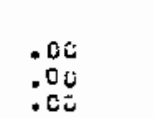 & $\begin{array}{l}.00 \\
.00 \\
.00\end{array}$ & $\begin{array}{l}.00 \\
.00 \\
.00\end{array}$ & $\begin{array}{l}.0 J \\
.05 \\
.00\end{array}$ & $\begin{array}{l}.00 \\
.00 \\
.00\end{array}$ & $\begin{array}{l}.06 \\
.00 \\
.00\end{array}$ & $\begin{array}{l}.00 \\
.00 \\
.00\end{array}$ \\
\hline
\end{tabular}

SUHMEO DOSE COMMITMENTS FOR 1B250. OAYE

\begin{tabular}{|c|c|c|}
\hline & LE COM & ENT \\
\hline 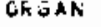 & HIGri-LE] & $20 \mathrm{~W}-L E \mathrm{~T}$ \\
\hline $\begin{array}{l}T \in O Y \\
R \text { GAR }\end{array}$ & $\begin{array}{l}.40 \\
.80\end{array}$ & $\begin{array}{l}1.39 E-0 S \\
2.19 E-0 S \\
1.055-05\end{array}$ \\
\hline
\end{tabular}

$03 / 12 / 60 ; 5.58 .42$

EXECUTION TIKE $=34$. LEZ SECONOS 
DFAIH RUN DA-

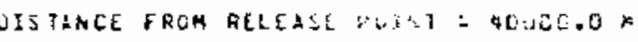

Dals 25

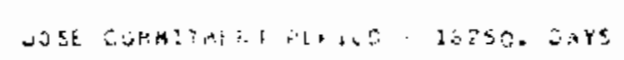

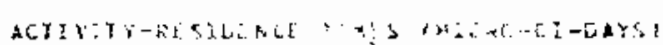

\begin{tabular}{|c|c|c|c|c|c|c|c|c|c|c|c|}
\hline & $M 1600-\hat{6}=$ & & & & & & & & & HE S & \\
\hline & $\operatorname{hrA}$ & $n=k$ & $k$ ratertas & 20 & & & & & G & AYKSH & thyoso \\
\hline $\begin{array}{l}128 \\
E \perp 33\end{array}$ & $\begin{array}{l}1.04 E-64 \\
3.16 E-51\end{array}$ & $\begin{array}{l}2.791=04 \\
.00\end{array}$ & $\begin{array}{l}0.50 i-25 \\
.00\end{array}$ & $\begin{array}{l}1.8 \varepsilon[-5.5 \\
.00\end{array}$ & 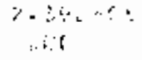 & $\begin{array}{l}\therefore 486 \cdot 07 \\
\therefore \quad 5\end{array}$ & $\begin{array}{l}:-3 f, \cdot 0 \% \\
\text { a } 380\end{array}$ & $\begin{array}{l}x+5=0 \\
x \rightarrow 0\end{array}$ & $\begin{array}{l}* 30-207 \\
+610\end{array}$ & $\begin{array}{l}x .758-30 \\
.50\end{array}$ & 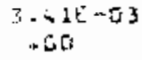 \\
\hline
\end{tabular}


WRAIIH RUN --
SAMPLE WRAITH RUN I-B-GGOUND LEVEL RELEASE

DISTANCE FRUK RELEASE POINT = 4DOJS +O H

CROSS ORGAN DOSE COKK:TMENTS FOR IÓ2SC.O DAYS (RROS)

\begin{tabular}{|c|c|c|c|c|c|c|c|c|c|c|c|}
\hline \multirow{3}{*}{$\underset{1}{\omega}$} & $\begin{array}{r}\text { SO } \\
\text { TARGET }\end{array}$ & WAES -OOHER & F ARÁtiU & LUNGS & LIVES & STOKACH & SM INT & U 1.5 INT & $\angle L G$ INT & $\begin{aligned} R E S P \\
\text { LYY.FH }\end{aligned}$ & THYROIO \\
\hline & $\begin{array}{l}\text { T } B C Y \\
R \text { KAR } \\
\text { L LNGS }\end{array}$ & $\begin{array}{c}\text { LOU LEI DOSES } \\
1.69 E-08 \\
7.80 E-09 \\
4.20 E-09\end{array}$ & $\begin{array}{l}4.51 E-C S \\
1.40 E-C 7 \\
3.5+E-10\end{array}$ & $\begin{array}{l}2.16 E-09 \\
2.81 E-10 \\
6.62 E-C 9\end{array}$ & $\begin{array}{l}1.47 E-C \theta \\
1.72 E-10 \\
4.7 C E-10\end{array}$ & $\begin{array}{l}4.19 E-11 \\
3.4 E E-12 \\
6.33 E-12\end{array}$ & $\begin{array}{l}8.70 E-12 \\
3.65 E-12 \\
1.69 E-14\end{array}$ & $\begin{array}{l}2 \cdot 8 z E-11 \\
1+595-11 \\
6+67 E-14\end{array}$ & $\begin{array}{l}5.16 E-11 \\
5.28 E-11 \\
1.35 E-14\end{array}$ & $\begin{array}{l}2.32 E-10 \\
5 . t 2 E-11 \\
1.32 E-08\end{array}$ & $\begin{array}{l}1.78 E-07 \\
6.1+E-09 \\
6.14 E-09\end{array}$ \\
\hline & $\begin{array}{l}\text { I ELY } \\
\text { F RAR } \\
\text { LLALS }\end{array}$ & $\begin{aligned} & \text { HIOH-LE T COSES } \text {. CO } \\
& .00 \\
& .00\end{aligned}$ & $\begin{array}{l}-03 \\
-50 \\
-00\end{array}$ & $\begin{array}{l}.05 \\
: 00 \\
.00\end{array}$ & $\begin{array}{l}.02 \\
.05 \\
.02\end{array}$ & $\begin{array}{l}.00 \\
.00 \\
.00\end{array}$ & $\begin{array}{l}.00 \\
.00 \\
.00\end{array}$ & $\begin{array}{l}.60 \\
.00 \\
.00\end{array}$ & $\begin{array}{l}.20 \\
.00 \\
.00\end{array}$ & $\begin{array}{l}.06 \\
.00 \\
.06\end{array}$ & $\begin{array}{l}.00 \\
.00 \\
.00\end{array}$ \\
\hline$x \in\{3 \leq$ & $\begin{array}{l}\text { T SCY } \\
\text { R KAR } \\
\text { LLTWS }\end{array}$ & $\begin{array}{c}\text { COA-LET DOSES } \\
\text { :DO } \\
\text { ODO } \\
\text {.UO } \\
\text { hIGH LET COSES }\end{array}$ & $\begin{array}{l}.03 \\
-05 \\
.05\end{array}$ & $\begin{array}{l}6.3 C E-09 \\
3.4 E E-66 \\
3.62 E-67\end{array}$ & $\begin{array}{l}.0 C \\
.00 \\
.00\end{array}$ & $\begin{array}{l}.05 \\
.00 \\
.00\end{array}$ & $\begin{array}{l}.00 \\
.00 \\
.00\end{array}$ & $\begin{array}{l}.00 \\
.00 \\
.00\end{array}$ & $\begin{array}{l}.20 \\
.00 \\
.00\end{array}$ & $\begin{array}{l}.0 \mathrm{C} \\
.0 \mathrm{C} \\
.00\end{array}$ & $\begin{array}{l}.00 \\
.00 \\
.00\end{array}$ \\
\hline & $\begin{array}{l}x \text { ELY } \\
R \text { MAA } \\
\text { LUAGS }\end{array}$ & $\begin{array}{l}.00 \\
.00 \\
.00\end{array}$ & $\begin{array}{l}.50 \\
.02 \\
.02\end{array}$ & $\begin{array}{l}.00 \\
.00 \\
.00\end{array}$ & $\begin{array}{l}.02 \\
.00 \\
.00\end{array}$ & $\begin{array}{l}.85 \\
.00 \\
.00\end{array}$ & $\begin{array}{l}.60 \\
.00 \\
.00\end{array}$ & $\begin{array}{l}.00 \\
.00 \\
.0 \mathrm{C}\end{array}$ & $\begin{array}{l}.00 \\
.00 \\
.00\end{array}$ & $\begin{array}{l}.0 \mathrm{C} \\
.0 \mathrm{C} \\
.0 \mathrm{C}\end{array}$ & $\begin{array}{l}.00 \\
.00 \\
.00\end{array}$ \\
\hline
\end{tabular}


WRAIIH KUh -
SAMPLL DRAIIH RUM 1-B--GROUND LEVEL RELEASE

OISTANCE FFGM RLLEASE POYNT $=$ WOOCC.O M

ChOSS ORGAN DUSE COKHITMENTS FOR 1B25C.C DAYS IRADS,

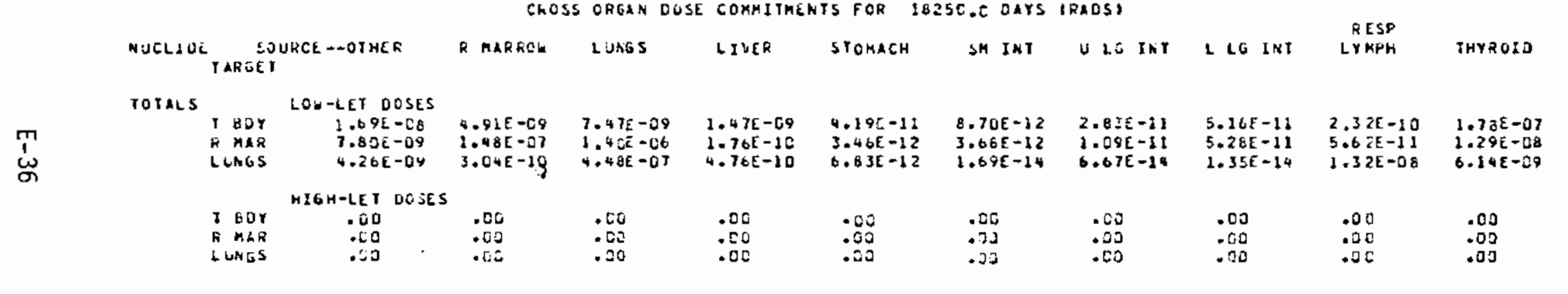

SUKMEO DOSE COMMIIMENTS FOR $1625 \mathrm{SL}$. DAYS

\begin{tabular}{|c|c|c|}
\hline r & DCSE COA & $E N Y$ \\
\hline OAGAN & HIGH-LET & CCd $-L C]$ \\
\hline T Siy & . & $8.69 \mathrm{i}-4 \delta$ \\
\hline LUNGS & .60 & $8.95 i-\pi 6$ \\
\hline
\end{tabular}

PALE 31

C3/12/80 $\quad 15.58 \cdot 42$ 
WRADTH RLIM -

JAKPLL WRAITH FUN 2-E--GRCUNO LEVEL RELLASE

PAGE 32

$03 / 12 / 80 \quad 25.58 .42$

OISTANCE FROH RELEASE POJHT $=75000.6 \mathrm{~K}$

EXTERAAL DCSES

$\begin{array}{lc}\text { NUCLIDE } & \text { DOSE GEPIH } \\ \text { DOSE (PACS) } \\ \text { I } 125 \\ X E 133 & 3.67 E-10 \\ & 3.07 E-26\end{array}$

$\stackrel{\omega}{\omega}$

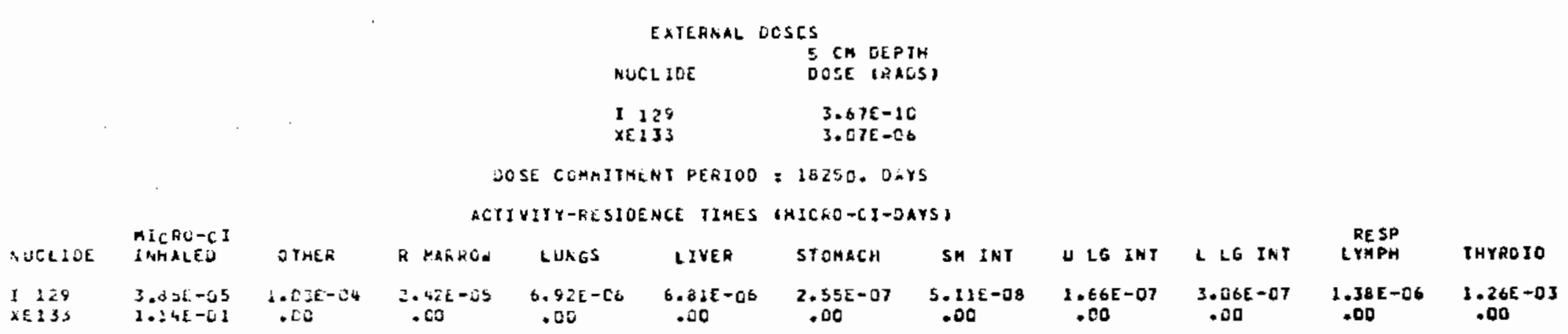




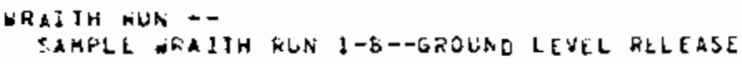

FAGE 33

$03112 / 80 \quad 15.58 .42$

DISTANCE FFOM RELEASE POINT $=75000.0 \mathrm{M}$

CHGSS ORCAN DOSE COMMITMENTS FOR IE250.0 OAYS RROS

\begin{tabular}{|c|c|c|c|c|c|c|c|c|c|c|c|}
\hline HUCLLOE & $\begin{array}{r}50 \\
\text { TAFLE: }\end{array}$ & UhCE - OF HE & R HARRO. & L LNG 5 & LIVER & STOMACH & SM INI & U LG INT & L LG INT & $\begin{array}{r}\text { RESP } \\
\text { LYMPH }\end{array}$ & THYROID \\
\hline I 120 & 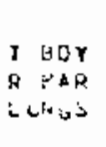 & 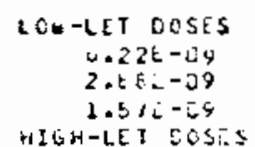 & $\begin{array}{l}1.61 E-08 \\
5.47 E-68 \\
1.22 E-10\end{array}$ & $\begin{array}{l}4.2 A E-10 \\
1.04 E-10 \\
2.44 E-28\end{array}$ & $\begin{array}{l}5.43 E-10 \\
6.48 E-11 \\
1.76 E-10\end{array}$ & $\begin{array}{l}1.55 E-12 \\
1.28 E-12 \\
2.52 E-12\end{array}$ & $\begin{array}{l}3.21 E-12 \\
1.36 E-12 \\
6.22 E-15\end{array}$ & $\begin{array}{l}1.04 E-11 \\
4.04 E-12 \\
2.46 E-14\end{array}$ & $\begin{array}{l}1.90 E-11 \\
1.95 E-11 \\
4.99 E-15\end{array}$ & $\begin{array}{l}8.57 E-11 \\
2.07 E-11 \\
4.87 E-09\end{array}$ & $\begin{array}{l}6.59 E-O B \\
2.27 E-09 \\
2.27 E-07\end{array}$ \\
\hline & 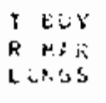 & $\begin{array}{l}.<0 \\
.30 \\
.60\end{array}$ & $\begin{array}{l}-20 \\
-0] \\
.00\end{array}$ & $\begin{array}{l}.00 \\
.02 \\
.00\end{array}$ & $\begin{array}{l}.02 \\
.05 \\
.00\end{array}$ & $\begin{array}{l}.25 \\
.03 \\
.02\end{array}$ & $\begin{array}{l}.00 \\
.00 \\
.30\end{array}$ & $\begin{array}{l}.00 \\
.00 \\
.00\end{array}$ & $\begin{array}{l}.00 \\
.60 \\
.00\end{array}$ & $\begin{array}{l}.02 \\
.02 \\
.00\end{array}$ & $\begin{array}{l}.00 \\
.00 \\
.00\end{array}$ \\
\hline$\therefore E+3.2$ & 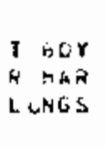 & 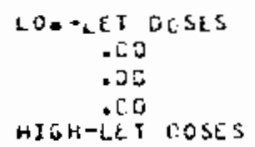 & $\begin{array}{l}.00 \\
.05 \\
.05\end{array}$ & $\begin{array}{l}2.25 E-08 \\
5.07 E-C 7 \\
i=34 E-67\end{array}$ & $\begin{array}{l}.20 \\
.00 \\
.00\end{array}$ & $\begin{array}{l}.00 \\
.03 \\
.00\end{array}$ & $\begin{array}{l}.00 \\
.00 \\
.00\end{array}$ & $\begin{array}{l}-\infty 0 \\
-\infty 00 \\
-00\end{array}$ & $\begin{array}{l}.00 \\
.00 \\
.00\end{array}$ & $\begin{array}{l}.00 \\
.0 \mathrm{C} \\
.0 \mathrm{C}\end{array}$ & $\begin{array}{l}.00 \\
.00 \\
.00\end{array}$ \\
\hline & $\begin{array}{l}T \text { EOY } \\
\text { K } K A R \\
\text { SUAS }\end{array}$ & $\begin{array}{r}+10 \\
.50 \\
-50\end{array}$ & $\begin{array}{l}.50 \\
.02 \\
.50\end{array}$ & $\begin{array}{l}.83 \\
.02 \\
.00\end{array}$ & $\begin{array}{l}\triangle 0 E \\
.50 \\
.06\end{array}$ & 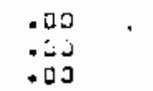 & $\begin{array}{l}.00 \\
.00 \\
.00\end{array}$ & $\begin{array}{l}.00 \\
.60 \\
.00\end{array}$ & $\begin{array}{l}.00 \\
.00 \\
.00\end{array}$ & $\begin{array}{l}.00 \\
.00 \\
.00\end{array}$ & $\begin{array}{l}.30 \\
.00 \\
.00\end{array}$ \\
\hline
\end{tabular}


WRAL Tit hUR --

SAMPLK WRAITH RUN 1-8--6ROUAO LEVEL FËLEASE

DISTANCE GROM FELEASE POINT $=75000.0 \mathrm{M}$

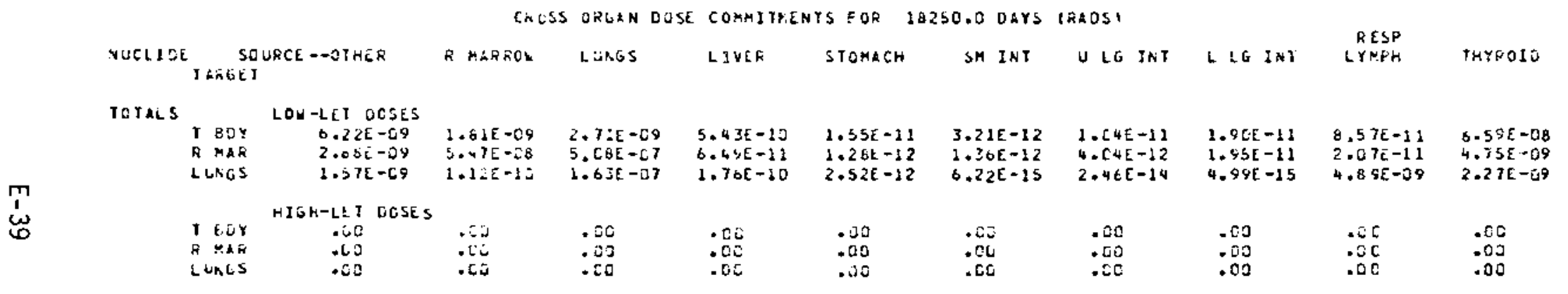

SUMKED OCSE COMMITKENTS FOR 1 SZSC. DAYS

\begin{tabular}{|c|c|c|}
\hline TAESET & $0 Q S, \vec{E}$ & $Y Y$ (RAD) \\
\hline ORGA:; & HIGH-LEI & $\left\{C_{N}-L E T\right.$ \\
\hline I $30 y$ & - Ca & $3-15 E-36$ \\
\hline $\begin{array}{l}\dot{M A a} \\
\operatorname{LUNGS}\end{array}$ & . & $\begin{array}{l}3.54 E=06 \\
3.25 E-06\end{array}$ \\
\hline
\end{tabular}

15.58 .42 
WRALTM KUIA-A -
SARPLE GRAITH RUN I-8--GROUNO LEVEL RELEASE

DISTANGE FROM RELEASE POINT $=100000.0 \mathrm{M}$

$$
\begin{aligned}
& \text { EXTERNAL DOSES } \\
& \begin{array}{l}
\text { NUCLIDE CH OEPTH } \\
\text { DOSE IRACS }
\end{array} \\
& \text { I } 129 \quad 2.18 E-10 \\
& \begin{array}{rl}
1.29 & 2.18 E-10 \\
x E 133 & 1.00 E-06
\end{array}
\end{aligned}
$$

\begin{tabular}{|c|c|c|c|c|c|c|c|c|c|c|c|}
\hline \multirow[b]{2}{*}{ VUCLIDE } & \multirow[b]{2}{*}{$\begin{array}{l}\text { HICRO-CI } \\
\text { INHALED }\end{array}$} & \multirow{2}{*}{\multicolumn{7}{|c|}{ ACTIVITHCRESIDEK }} & \multirow{2}{*}{\multicolumn{3}{|c|}{ RESP }} \\
\hline & & & & & & & & & $L \angle G: N\}$ & & THYROID \\
\hline $\begin{array}{r}\$ 29 \\
+\quad 333\end{array}$ & $\begin{array}{l}2.28 E-05 \\
6.68 E-52\end{array}$ & $\begin{array}{l}6.08 E-05 \\
.00\end{array}$ & $\begin{array}{l}1.43[-05 \\
.00\end{array}$ & $\begin{array}{l}4.10 E-C 6 \\
.00\end{array}$ & $\begin{array}{l}5.21 \varepsilon-06 \\
.00\end{array}$ & $\begin{array}{l}2.51 E-07 \\
.00\end{array}$ & $\begin{array}{l}3.02 \mathrm{E}-\mathrm{DS} \\
.00\end{array}$ & $\begin{array}{l}9.80 E-08 \\
.00\end{array}$ & $\begin{array}{l}2.81 \mathrm{E}-6.7 \\
.00\end{array}$ & $\begin{array}{l}8.20 E-07 \\
.00\end{array}$ & $\begin{array}{l}7.46 E-04 \\
.00\end{array}$ \\
\hline
\end{tabular}

DOSE COMHITKENI PERIOO: 18250. DAYS

ACYIYITY-RESIDENCE TIAES (HICRO-CI-DAYS,
PAEE 35

$03 / 12 / 80 \quad 15.58 .42$$$
.00 \quad .00
$$ 
WRALTH KUN -.

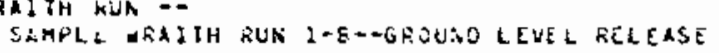

PAGE 36

$53 / 12 / 80$

15.53 .42

OLSTANCE FRCH RELEASE PCINT =1000OU. 4

ChOSS ORLAN CQSE COMMLMENTS FOA 18250.0 DAYS IRADSS

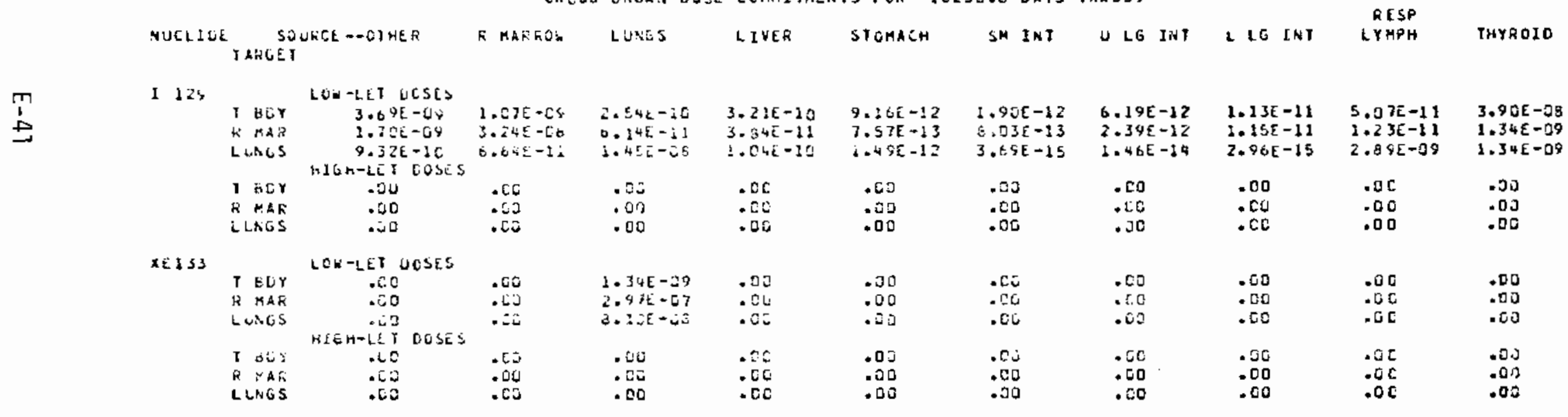


VRAiIH GUN --

SAAPLC MRAITH HUN 1-6--GROUNO LEVEL RELEASE

DISTAMCE FFOM RELEASE POINT $=! C O 0 O 0 . \mathrm{K}$

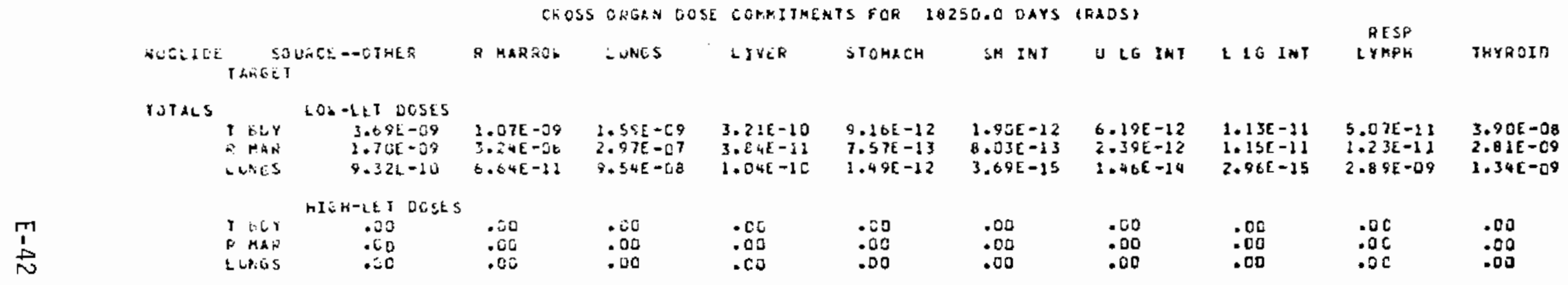

SUAMEL DOSE COMMITEENTS FOR :325E. DAYS

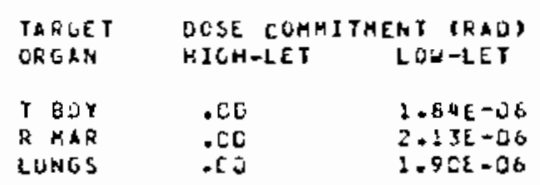

EXECUTION YIME $=34.3 E C$ SECONOS 


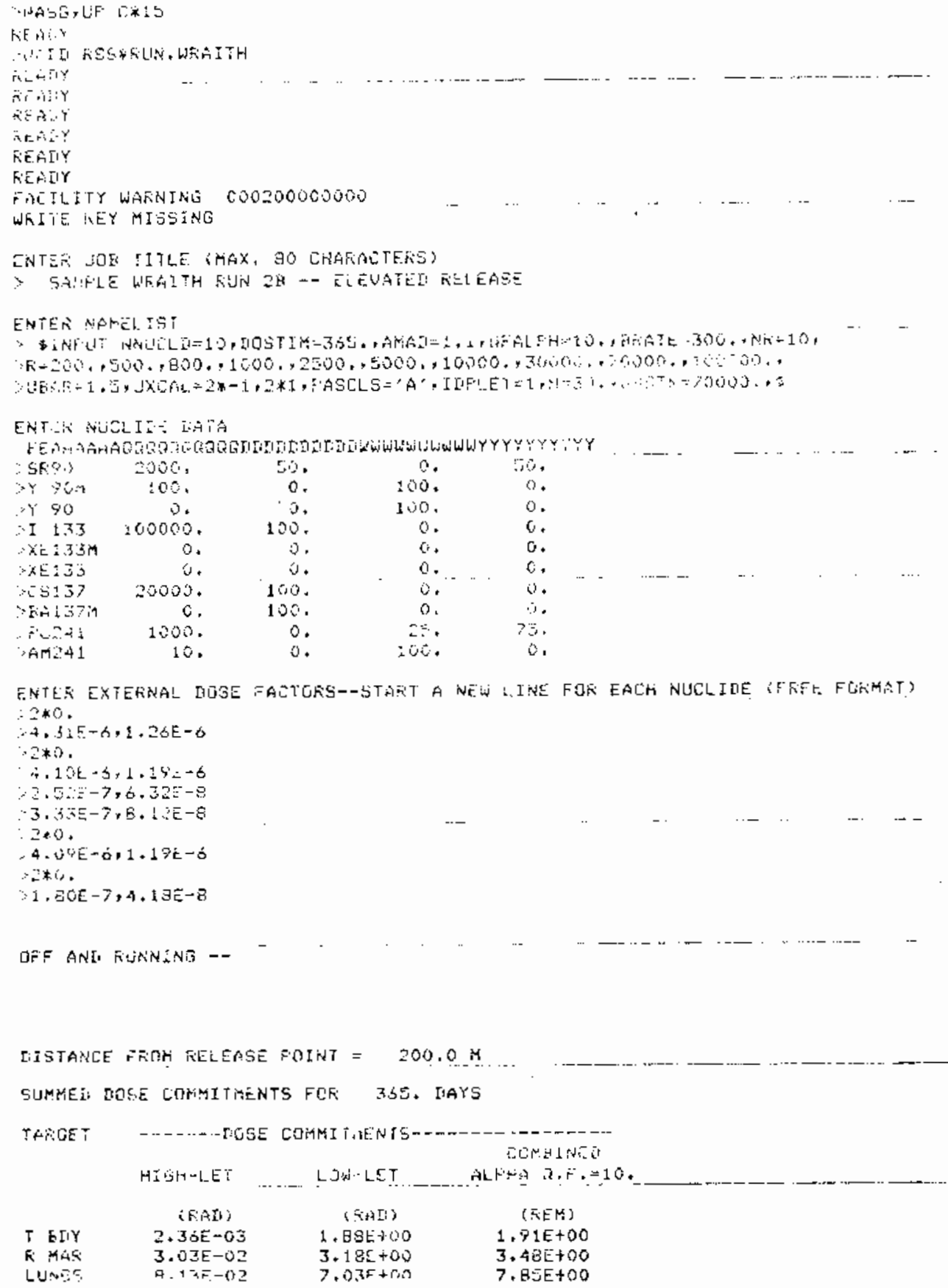




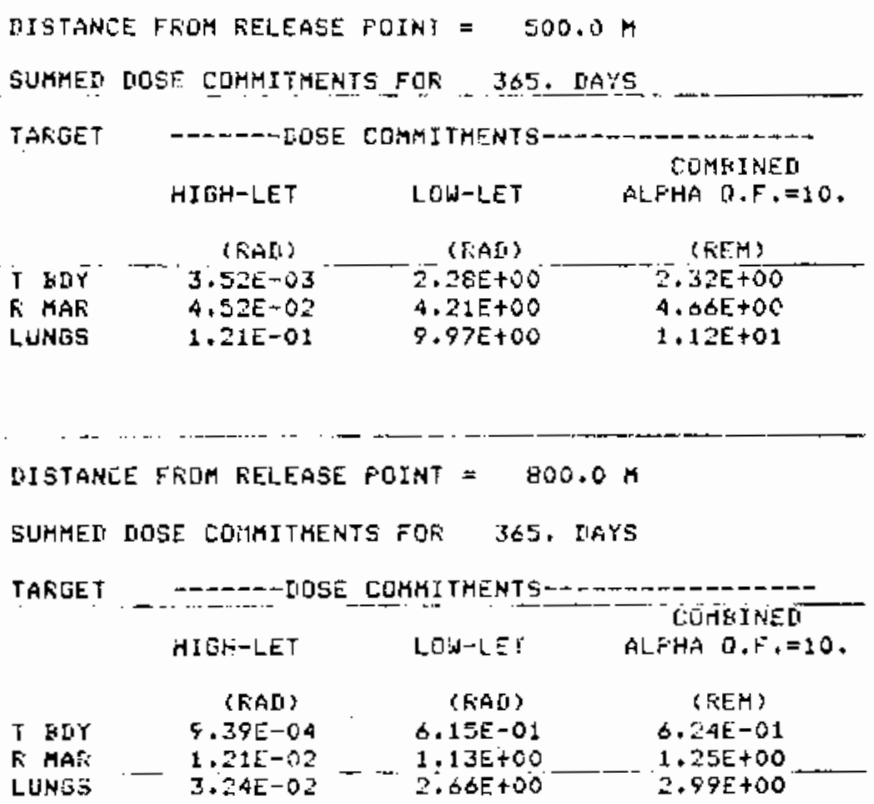




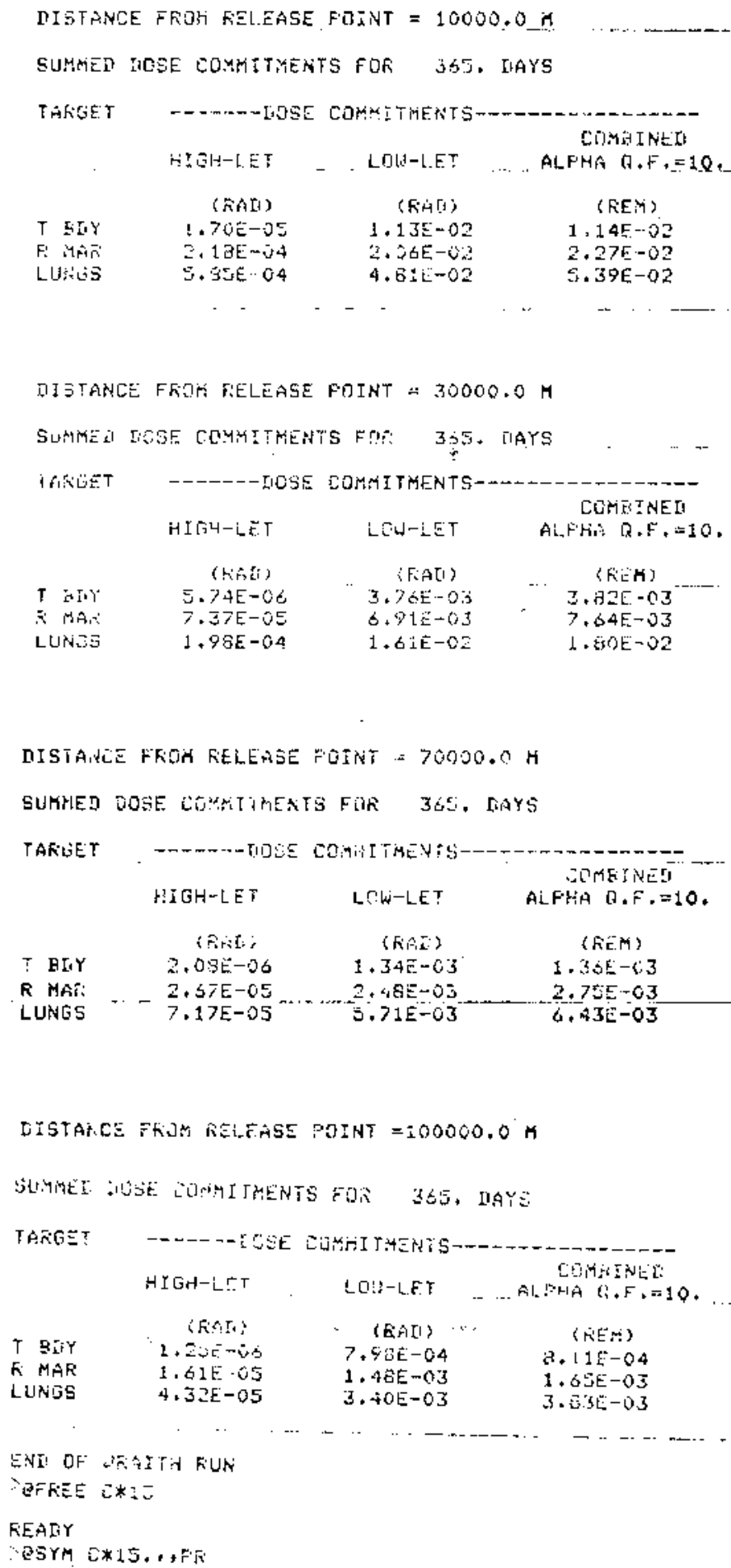


Line Printer Output for Sample Run 2

NOTE: Text appears in microfiche form at end of report. 


\section{DISTRIBUTION}

No. of

Copies

OFFSITE

\author{
A. A. Churm \\ DOE Patent Division \\ 9800 S. Cass Avenue \\ Argonne, IL 60439 \\ 218 U.S. Nuclear Regulatory \\ Commission \\ Division of Technical Information \\ and Document Control \\ 7920 Norfolk Avenue \\ Bethesda, MD 20014 \\ 2 DOE Technical Information Center \\ 10 Frank Swanberg, Jr., Chief \\ Environmental Effects Research \\ Branch \\ Division of Safeguards, Fuel \\ Cycle \& Environmenta? Research \\ U.S. Nuclear Regulatory Commission \\ Washington, D.C. 20555 \\ J. A. S. Armbruster \\ Environmenta] Research and \\ Technology \\ P. 0. Box 2105 \\ Ft. Collins, C0 80522 \\ 3 F. J. Borst \\ Ft. St. Vrain \\ Public Service Company of \\ Colorado \\ Platteville, c0 80651 \\ D. C. Kocher \\ Bldg. 7509 \\ P. 0. Box $X$ \\ Oak Ridge National Laboratory \\ Oak Ridge, TN 37830
}

No. of

Copies

P. LeClare

C. T. Main

Prudential Center

Boston, MA 02T99

C. A. Little

B1dg. 7509

P. 0. Box $X$

Oak Ridge National Laboratory

Oak Ridge, TN 37830

R. L. Roswel?

Radiobiology Division

B1dg. 351

University of Utah

Salt Lake City, UT 84112

K. T. Tran

Environmental Research and

Technology

2625 Townsgate Rd.

Westlake Village, CA 91361

J. W. Poston

School of Nuclear Engineering

Georgia Inst. of Technology

Atlanta, GA 30332

T. J. Froelich

Washington Public Power Supply

System

300 George Washington Way

Richland, WA 99352 
No. of

Copies

ONSITE

42 Pacific Northwest Laboratory

A.E. Desrosiers

L.G. Faust

R.E. Filipy

J.J. Fix

D.L. Haggard

G. R. Hoenes

W. D. McCormack

S.G. McNeece

R. McPherson

W.D. Meitzler

B.A. Napier

R.I. Scherpelz (20)

J.K. Soldat

G.A. Stoetzel

D.L. Strenge

E.C. Watson

Technical Information (5)

Publishing Coordination (2) 

4. TITLE AND SUBTITLE (Add Volume No, if appropriate)

WRAITH - A Computer Code for Calculating Internal and External

Doses Resulting from an Atmospheric Release of Radioactive Material

7. AUTHORIS!

R.I. Scherpelz, F.J. Borst, G.R. Hoenes

9. PERFORMING ORGANIZATION NAME AND MAILING ADDRESS inchude Zip Code)

Racific Northwest Laboratory

Richland, WA 99352

3. RECIPIENT'S ACCESSION NO.

DATE REPOAT COMPLETED

\begin{tabular}{l|l}
\hline MON TH & YEAR \\
\hline
\end{tabular}

August 1980

\begin{tabular}{l|l} 
DATE REPORT ISSUED & \\
\hline MONTH & YEAR \\
December & 1980
\end{tabular}

6. (Leave blank)

B. (Leave blank)

12. SPONSORING ORGANIZATION NAME AND MAILING ADDRESS inciude $Z i p$ Cude'

10. PROJECT:TASKIWORK UNIT NO.

U.S. Nuclear Regulatory Commission

Division of Safeguards, Fuel Cycle and Environmental Research

11. CONTRACT NO

Office of Nuclear Regulatory Research

Washington, DC. 20555

13. TYPE OF REPORT

PEAIOD COVERED (Inciusive dates)

15. SUPPLEMENTARY NOTES

14. (Leave of ank)

16. ABSTRACT (200 words or less)

WRAITH is a FORTRAN computer code which calculates the doses received by a standard man exposed to an accidental release of radioactive material. The movement of the released material through the atmosphere is calculated using a bivariate straight-line Gaussian distribution model, with pasquill values for standard deviations. The Quantity of material in the released cloud is modified during its transit time to account for radioactive decay and daughter production. External doses due to exposure to the cloud can be calculated using a semi-infinite cloud approximation. In situations where the semi-infinite cloud approximation is not a good one, the external dose canbe calculated by a "finite plume" three-dimensional point-kernel numerical integration technique. Internal doses due to acute inhalation are calculated using the ICRP Task Group Lung Model and a four-segmented gastro-intestina? tract model. Translocation of the material between body compartments and retention in the body compartments are calculated using multiple exponential retention fuctions. Internal doses to each organ are calculated as sums of cross-organ doses, with each target organ irradiated by radioactive material in a number of source organs. All doses are calculated in rads, with separate values determined for high-LET and low-LET radiation.

\begin{tabular}{|c|c|}
\hline $\begin{array}{l}\text { 1:J SELRTYCLASS (This roport! } \\
\text { Unclassified }\end{array}$ & 21 VO OT PACAS \\
\hline $\begin{array}{l}20 \text { SECU HI TY Cl ASS Th:s Douel } \\
\text { Unclassifjed }\end{array}$ & $\begin{array}{c}22 \text { FHICF } \\
5\end{array}$ \\
\hline
\end{tabular}


